\title{
The Shadow of the Neolithic Revolution on Life Expectancy:
}

\section{A Double-Edged Sword*}

\author{
Raphaël Franck ${ }^{\dagger}$ Oded Galor; Omer Moav, and Ömer Özak $\mathbb{I}^{\S}$
}

February 28, 2022

\begin{abstract}
This research explores the persistent effect of the Neolithic Revolution on the evolution of life expectancy in the course of human history. It advances the hypothesis and establishes empirically that the onset of the Neolithic Revolution and the associated rise in infectious diseases triggered a process of adaptation reducing mortality from infectious diseases while increasing the propensity for autoimmune and inflammatory diseases. Exploiting an exogenous source of variation in the timing of the Neolithic Revolution across French regions, the analysis establishes the presence of these conflicting forces - the beneficial effects on life expectancy before the second epidemiological transition and their adverse effects thereafter.
\end{abstract}

Keywords: Life Expectancy, Health, Mortality, Neolithic Revolution, Epidemiological Transition, Infectious Disease, Auto-immune Disease, Diabetes, Crohn's Disease, HIV, COVID-19

JEL Classification: I10, I15, J10, N00, N30, O10, O33, Z10

${ }^{*}$ We wish to thank Matteo Cervellati, Daniele Paserman, Uwe Sunde, David Weil, as well as participants at the $6^{\text {th }}$ EH-Cliolab Conference, and seminar participants at Bonn University, Brown University, Hebrew University of Jerusalem, and Lille Catholic Institute for helpful suggestions.

${ }^{\dagger}$ Hebrew University of Jerusalem, Dept. of Economics, CEPR and CESIfo. Email: Raphael.Franck@mail.huji.ac.il

${ }^{\ddagger}$ Brown University, Dept. of Economics, NBER, CEPR, IZA, GLO and CESifo, E-mail: Oded_Galor@brown.edu

${ }^{\S}$ University of Warwick, Reichman University, and CEPR. E-mail: omer.moav100@gmail.com

${ }^{I}$ Southern Methodist University, Dept. of Economics, IZA and GLO. PO Box 0496, Dallas, TX 75275-0496. E-mail: ozak@smu.edu. Tel: (214) 768-2755. Fax: (214) 768-1821. ORCID 0000-0001-6421-2801. 


\section{Introduction}

The Neolithic Revolution - the transition from hunter-gatherer tribes to agricultural societies and from a nomadic lifestyle to sedentary living and was one of the most significant transformations in human history. ${ }^{1}$ It fostered social stratification and contributed to the emergence of a non-foodproducing class dedicated to advancements in art, science, and technology, leading ultimately to the onset of civilization. ${ }^{2}$ Regions that experienced the Neolithic Revolution earlier benefited from a technological head start as well as growth-enhancing adaptations in cultural and individual traits to the novel agricultural setting. ${ }^{3}$ In particular, the rise in population density, the domestication of animals, and the increase in work effort in the course of the Neolithic Revolution triggered the first epidemiological transition: it intensified the exposure and the vulnerability of humans to infectious diseases, and generated adaptations of the human immune system to the novel disease environment created by the Neolithic lifestyle. ${ }^{4}$ This evolutionary process affected both the innate and adaptive immune systems, increasing genetic resistance to the new pathogens, and fostering immunological resistance. ${ }^{5}$

This research explores the persistent effect of the Neolithic Revolution on life expectancy in the course of human history. It advances the hypothesis that the onset of the Neolithic Revolution, and the associated rise in infectious diseases, triggered a process of adaptation that increased the prevalence of hyperactive immune systems in human populations and mitigated the mounting mortality from infectious diseases. Yet, these overactive and hypersensitive immune systems elevated the predisposition towards autoimmune and inflammatory diseases. ${ }^{6}$ Thus, human adaptation brought about by the Neolithic Revolution generated a double-edged sword: it lowered mortality from infectious diseases while increasing morbidity and mortality from inflammatory and autoimmune diseases. On the whole, these conflicting forces had a beneficial impact on life expectancy, as long as mortality from infectious diseases was the predominant cause of death. The longer ancestral populations were exposed to this evolutionary pressure, the better the immune system of their descendants protected against infectious diseases, and the higher was their life expectancy. But the second epidemiological transition, characterized by the adoption of hygienic practices based on the germ theory of disease, the introduction of antibiotics, massive immunization campaigns, and the establishment of modern health infrastructures in the twentieth century, has diminished mor-

\footnotetext{
${ }^{1}$ Childe (1951); Diamond (2002); Bocquet-Appel and Bar-Yosef (2008).

${ }^{2}$ Althabe (1965); Claessen and Skalník (1978); Allen (1997); Kohler et al. (2017); Turchin et al. (2018).

${ }^{3}$ Diamond (1997); Bocquet-Appel (2011); Atkinson and Whitehouse (2011); Turchin et al. (2013); Galor and Özak (2016); Galor et al. (2018).

${ }^{4}$ McNeill (1989); Bellwood (2005); Wolfe et al. (2007); Armelagos et al. (1991); Dobson and Carper (1996); Steckel and Rose (2002); Cohen et al. (2013); Anderson and May (1991); Voight et al. (2006); Wang et al. (2006); Cohen and Crane-Kramer (2007); Cochran and Harpending (2009); Laland et al. (2010); Karlsson et al. (2014); Mathieson et al. (2015); Nielsen et al. (2017).

${ }^{5}$ Barreiro and Quintana-Murci (2010); Dobson and Carper (1996).

${ }^{6}$ Relatedly, the Hygiene Hypothesis (Armelagos and Barnes, 1999; Velasquez-Manoff, 2012), posits that the contemporary increase in autoimmune and inflammatory diseases is a by-product of the exposure of the human immune system, which evolved in a pathogen-filled environment over millennia, to the pathogen-free environment generated by the contemporary development process. Moreover, it was most recently observed in the extreme reaction of the immune system to Covid-19 (Corona et al., 2010).
} 
tality from infectious diseases and thus the benefits of hyperactive immune systems. The impact of the adaptation process to the Neolithic Revolution became a liability, adversely affecting life expectancy thereafter. ${ }^{7}$ Among present-day descendants of ancestral populations that were exposed to this evolutionary pressure over a longer period, the prevalence of autoimmune diseases has been higher, and life expectancy has been lower.

Exploiting an exogenous source of variation in the onset of the Neolithic Revolution across French regions, the analysis identifies the impact of this transition on the reduction in mortality from infectious diseases along with the increase in the prevalence of inflammatory and autoimmune diseases. Moreover, it shows that these conflicting forces had beneficial effects on life expectancy prior to the second epidemiological transition, but generated adverse effects from the 1950s onwards. The empirical analysis exploits highly reliable, spatially disaggregated archaeological data on the timing of the Neolithic Revolution across France, based on carbon-14 dating, ${ }^{8}$ along with extensive high quality historical and contemporary data on health outcomes (i.e., mortality and morbidity from various sources, as well as the evolution of life expectancy, over the past two centuries). In particular, it establishes the validity of the proposed hypothesis in three different samples reflecting various levels of aggregation: (i) aggregate health outcomes across 89 administrative divisions of the French territory known as départements over the period 1801-2013, (ii) aggregate health outcomes across 593 French towns in the year 1900, and (iii) disaggregated data on individuals in present-day France.

The analysis accounts for a large set of confounding geographical characteristics and measures of economic development that could be correlated with health outcomes and the onset of the Neolithic Revolution. Nonetheless, given the potential role of omitted variables and reverse causality in the observed outcomes (e.g., the possibility that the actual timing of the Neolithic Revolution had been affected by the ability of ancestral populations to resist infectious diseases), the analysis implements an instrumental variable strategy to establish the causal effect of the Neolithic Revolution, using the predicted timing of the transition to agriculture across French regions, rather than the actual one. Specifically, since the timing of the Neolithic Revolution across Europe was determined by the demic diffusion of agricultural practices from Anatolia, ${ }^{9}$ the predicted timing of the Neolithic Revolution across French regions can be inferred from the projected demic diffusion of these agricultural practices from all archaeological sites outside France. ${ }^{10}$

In line with our hypothesis, the analysis establishes a large positive effect of the timing of the Neolithic Revolution on life expectancy across French départements during the $19^{\text {th }}$ century, prior to the introduction of major medical and sanitation innovations (Figure 1(a)). The estimated effect accounts for confounding geographical characteristics (e.g., latitude, suitability of land for agriculture,

\footnotetext{
${ }^{7}$ Appendix B.1 shows changes in the composition of mortality due to infectious and auto-immune diseases across age groups and genders in France.

${ }^{8}$ Pinhasi et al. (2005)

${ }^{9}$ Sokal et al. (1991); Menozzi and Cavalli-Sforza (1993); Pinhasi et al. (2005); Skoglund et al. (2012); Mathieson et al. (2015); Hofmanová et al. (2016); Lazaridis et al. (2016); Nielsen et al. (2017).

${ }^{10}$ Moreover this empirical strategy overcomes potential excavation biases in existing Neolithic sites within France, which may reflect economic development and geographical characteristics.
} 
elevation, ruggedness, temperature, precipitation, climatic volatility, share of area within $100 \mathrm{~km}$ of the sea, length of coast), their historical levels of population density, urbanization, and measures of economic development, such as GDP per capita, and human capital, across départements. The estimates imply for instance that in the 1871-75 period, a one standard deviation increase in the number of years elapsed since the historical territory of a French département experienced the Neolithic Revolution is associated with a 0.58 standard deviation increase in log-life expectancy, i.e., a sizable $8.7 \%$ increase (3.3 years at the mean) in life expectancy.

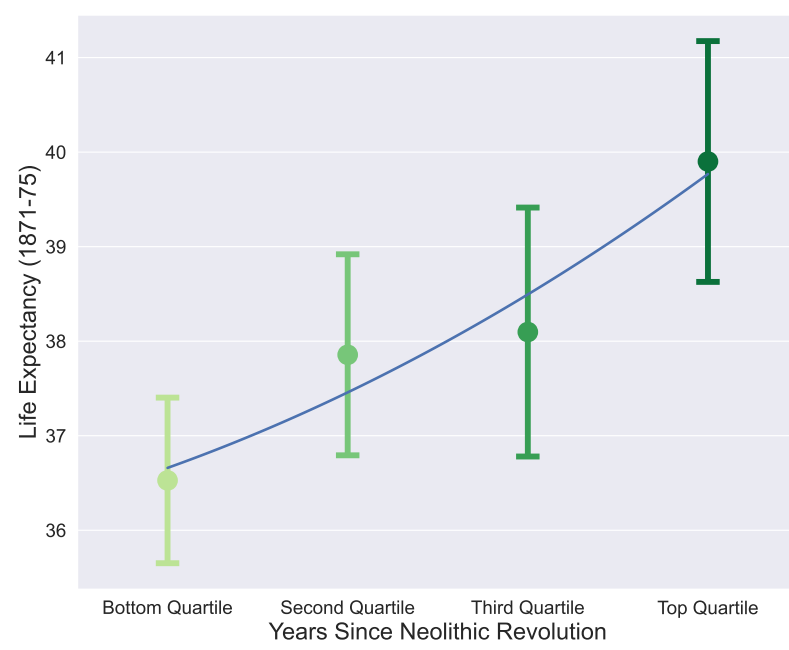

(a) $1871-1875$

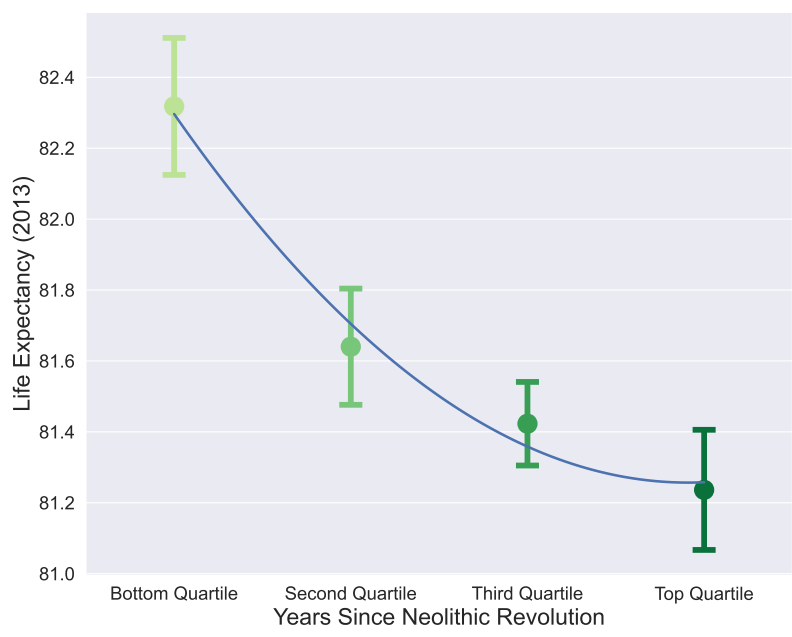

(b) 2013

Figure 1: Life Expectancy Across French Départements before and after the Second Epidemiological Transition, conditional on the Timing of the Neolithic Revolution

The analysis further suggests that the timing of the Neolithic Revolution had a large negative effect on life expectancy across French départements after the implementation of major medical and sanitation innovations (Figure 1(b)). The estimates imply that, for instance in 2013, a one standard deviation increase in the number of years since the historical territory of a French département experienced the Neolithic Revolution, is associated with 0.92 standard deviations decrease in loglife expectancy, i.e., about a $1 \%$ decrease (0.82 years at the mean) in life expectancy. This estimated effect is robust to accounting for various geographical characteristics of the départements, as well as proxies of development, including migration and population movements within France.

Moreover, the analysis supports the proposed mechanism behind the overall effect of the Neolithic Revolution on life expectancy. Exploring the effect of the Neolithic transition on mortality rates across French towns as well as across départements in 1900, (i.e., prior to the second epidemiological transition), the analysis suggests that there is a highly significant negative effect of the timing of the Neolithic Revolution on mortality from infectious diseases, accounting for a host of potential confounders at the town- and département-level. Reassuringly, there is no significant association between the timing of the Neolithic Revolution and non-immune mediated deaths, like suicides and violent deaths. 
The analysis further explores the mechanism underlying the adverse effect of the time elapsed since the Neolithic Revolution on present-day life expectancy. In line with our hypothesis, it shows that across French départements over the 2000-2013 period, there is a significant positive impact of the timing of the Neolithic Revolution on morbidity and mortality from various autoimmune and inflammatory diseases (e.g., diabetes, Crohn's disease and ulcerative colitis) as well as on the incidence of heart disease related to inflammation. Importantly enough, several placebo tests lend further credence to the hypothesis that the effect of the Neolithic Revolution on mortality is mediated by the adaptation of the immune system. In particular, there is no association between the time elapsed since the Neolithic Revolution and deaths from non-immune related sources such as: (i) heart failure related to mechanical problems (e.g., a dysfunctional heart valve), (ii) alcohol abuse, (iii) accidents, and (iv) suicides.

Furthermore in line with the main hypothesis, the beneficial protective effects of an earlier exposure to the Neolithic Revolution have persisted beyond the second epidemiological transition for diseases whose prevalence have not been sufficiently mitigated by effective vaccines or antibiotics. In particular, the analysis indicates that the timing of the Neolithic Revolution has a significant negative impact on morbidity and mortality from tuberculosis - a disease for which existing vaccines have low efficacy and some recent strands of the disease are drug resistant. ${ }^{11}$

Finally, the analysis explores the proposed hypotheses using present-day disaggregated data on the health status of individuals across France. Reinforcing the findings based on aggregate data, the empirical analysis suggests that individuals originating from French regions that experienced the Neolithic Revolution earlier are more likely to report a lower general health status, as well as the presence of chronic illness and disability.

\section{Empirical Strategy and Data}

This section presents our empirical strategy that is designed to identify the causal effect of the time elapsed since the Neolithic Revolution on mortality rates from various causes, on the prevalence of infectious and autoimmune disease, on life expectancy as well as on health outcomes. It also discusses the various datasets employed in the analysis, and the methodology used in the construction of the novel measures for the timing of the Neolithic Revolution in France.

\subsection{Identification Strategy}

The empirical analysis exploits an exogenous source of variations in the onset of the Neolithic Revolution across France to identify the impact of the time elapsed since the Neolithic Revolution on the evolution of life expectancy in French regions in the course of human history. The identification of this causal effect faces three major hurdles:

(i) The association between the timing of the Neolithic Revolution and various health outcomes is likely to be affected by geographical, institutional, cultural, or human characteristics that

\footnotetext{
${ }^{11}$ Lawn and Zumla (2011); Luca and Mihaescu (2013).
} 
may have affected those health outcomes and are associated with the timing of the Neolithic Revolution.

(ii) A positive association between the time elapsed since the Neolithic Revolution and life expectancy may reflect reverse causality due to the sorting of ancestral populations with greater resistance to infectious diseases and thus higher life expectancy into the challenging regions that experienced the Neolithic Revolution earlier.

(iii) The persistent effect of an earlier onset of the Neolithic Revolution on the process of development and the material well-being of the population contributed directly to the improvements in health and life expectancy, irrespective of adaptation.

The analysis employs several strategies to mitigate these concerns and to identify the immunemediated impact of the time elapsed since the Neolithic Revolution on life expectancy.

First, the analysis is conducted across regions within a single political entity, mitigating the potential role of variations in national institutions in the observed pattern and mitigating potential concerns about differential data quality that could affect the reliability of a cross-country analyses. In particular, variations in the timing of the Neolithic Revolution and health outcomes across French départements offer an ideal laboratory for the analysis, due to: (a) the existence of extensive, high quality data on historical and present-day health outcome across these French regions and towns. (b) The orthogonality of the size and the shape of the territory of each département to the process of development as they were designed in 1790 to ensure that the travel distance by horse from each location within the département to its administrative center would not exceed one day. (c) The existence of a uniform set of legal and political institutions imposed on those départements since 1804. (d) France has been religiously homogeneous since the end of the $17^{\text {th }}$ century, with the average share of Catholics across départements equal to $98 \%$ in 1861; and (e) the French language progressively replaced local languages so that the country became nearly linguistically homogeneous in the course of the $19^{\text {th }}$ century.

Second, the empirical analysis accounts for a large set of potentially confounding geographical characteristics that could have been associated with the onset of the Neolithic Revolution and could have affected health outcomes, independently of the proposed adaptation channel. These geographical characteristics include latitude, agricultural productivity and suitability, elevation, ruggedness, temperature, precipitation, climatic volatility, share of the département's territory within $100 \mathrm{~km}$ of the sea, and the length of coastline.

Third, to counter the possibility that reverse causality affects the observed relationship between the Neolithic Revolution and health outcomes, as would be the case if the actual timing of the Neolithic Revolution had been affected by the ability of ancestral populations to resist infectious diseases, and to further mitigate concerns about omitted confounding factors, the empirical analysis employs an instrumental variable strategy to establish the causal effect of the Neolithic Revolution on the evolution of life expectancy. Specifically, since the timing of the Neolithic Revolution across Europe was determined by the demic diffusion of agricultural practices from Anatolia (in present- 
day Turkey), ${ }^{12}$ the predicted timing of the Neolithic Revolution across French regions, as inferred from the projected demic diffusion of these agricultural practices from all archaeological sites outside of France is used as an instrumental variable for the timing of the transition to agriculture across French regions. ${ }^{13}$ The identifying assumption is therefore that, conditional on the set of geographical controls in region $i$, the predicted timing of the Neolithic Revolution in the region is uncorrelated with other characteristics in the region and has no direct impact on life expectancy or health outcomes in the region, only an indirect effect via its impact on the actual timing of the Neolithic Revolution in the region.

Fourth, the impact of the Neolithic Revolution on health outcomes may still not reflect a process of adaptation. It is entirely plausible that the Neolithic Revolution set in motion major socioeconomic transformations that had a lasting impact on the process of development and consequently had beneficial heath outcomes. Thus, the analysis accounts for various measures of economic development such as population density, urbanization rates, and income per capita to assure that the established effect is indeed mediated by the process of adaptation of the immune system and not by economic development. Importantly, it should be noted, however, that this development channel would have generated beneficial effects on health outcomes, universally, without implying the hypothesized conflicting effects on life expectancy.

\subsection{Data}

\subsubsection{Predicted Onset of the Neolithic Revolution}

This section presents the novel measures for the timing of the Neolithic Revolution across France, and in particular, the construction of the instrumental variable which is central to our identification strategy.

The primary data source for the timing of the Neolithic Revolution in France is the carbon-14 dating of 765 early Neolithic sites in Europe, the Near East, and Anatolia (Pinhasi et al., 2005). ${ }^{14}$ Figure 2 shows the location of these Neolithic sites with the calibrated radiocarbon timing of the Neolithic Revolution at each site in Europe and the Near East (Figure 2a), as well as in France (Figure 2b).

Based on this data, the timing of the Neolithic Revolution is projected to all $5^{\prime} \times 5^{\prime}$ grid cells within the convex hull of the location of the archaeological sites, which includes France, using the inverse weighted distance projection method. Specifically, the predicted time elapsed since the onset of the Neolithic Revolution in cell $i, \widehat{N R}_{i}$, is the distance-based weighted average of the onset

\footnotetext{
${ }^{12}$ Sokal et al. (1991); Menozzi and Cavalli-Sforza (1993); Pinhasi et al. (2005); Skoglund et al. (2012); Mathieson et al. (2015); Hofmanová et al. (2016); Lazaridis et al. (2016); Nielsen et al. (2017).

${ }^{13}$ This instrumental variable strategy is also applicable if the diffusion of agricultural practices was predominantly cultural rather demic. Moreover, the use of the predicted timing of the Neolithic Revolution, rather than the actual one, overcomes potential-excavation biases, reflecting differential development and geographical characteristics across France.

${ }^{14}$ The data set was constructed to shed light on the diffusion of the Neolithic Revolution to Europe, and it consists of all available Neolithic sites for which the mean timing since the Neolithic Revolution has a standard error lower than 200 radiocarbon years.
} 


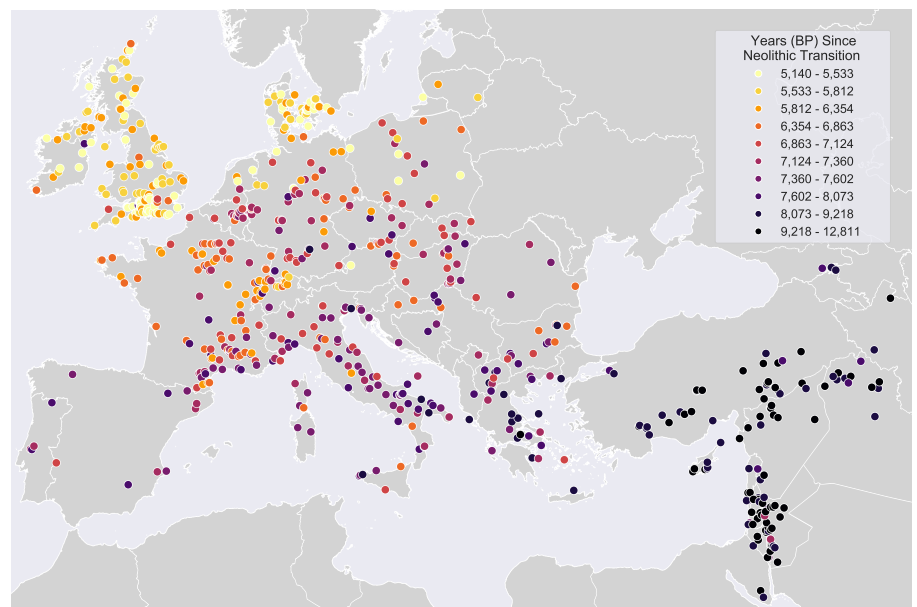

(a) Europe and the Middle-East

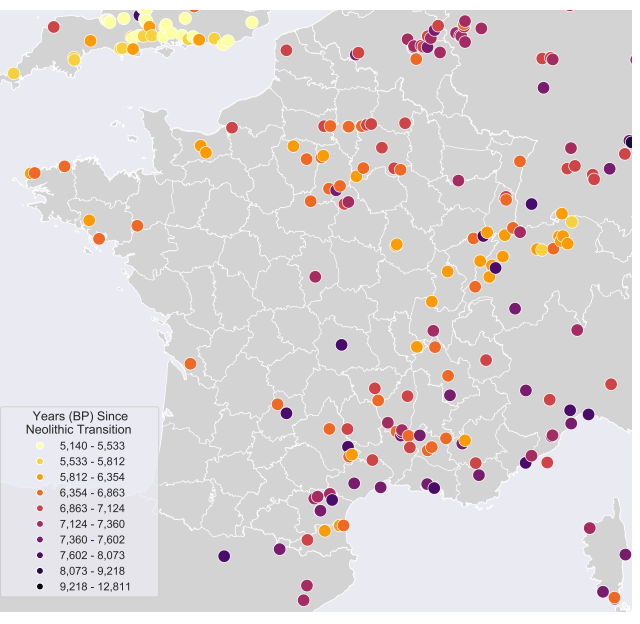

(b) France

Figure 2: Neolithic Sites - Location and Years Since Neolithic Revolution

of the Neolithic Revolution in the set of $N$ closest archaeological sites to cell $i, \mathcal{N}_{i}$. Hence,

$$
\widehat{N R}_{i}=\sum_{j \in \mathcal{N}_{i}} w\left(d_{i j}\right) N R_{j}
$$

where $N R_{j}$ is the timing of the onset of the Neolithic Revolution in archaeological site $j,\left\{w\left(d_{i j}\right)\right\}$ with $w^{\prime}\left(d_{i j}\right)<0$ is the set of weights that depends on the set of distances to location $i$, and are given by

$$
w\left(d_{i j}\right)=\frac{d_{i j}^{-p}}{\sum_{j \in \mathcal{N}_{i}} d_{i j}^{-p}} .
$$

Based on this method, various measures of the time elapsed since the Neolithic Revolution are constructed using different sets of neighboring Neolithic sites and different values of $p$ (i.e., $p=1,2,4)$. The measure used in the main analysis assumes that the 16 closest neighboring Neolithic sites are used in the interpolation (i.e., $N=16$ ) and the decay parameter in the weights is $p=4$ (i.e., it assumes a significant decline in the relative importance of distant Neolithic sites). Moreover, based on these assumptions, the analysis uses two distinct measures based on interpolations using (i) the set of all 765 Neolithic sites in the sample $\left(\widehat{N R}_{i}\right)$, and (ii) the set of all sites excluding sites located in France $\left(\widehat{N R}_{i} N F\right)$. This second measure is then used as an instrumental variable for the first one. The département-level and town-level measures are the mean of these cell-level measures across cells in the département or within $10 \mathrm{kms}$ of towns.

Figure 3 depicts the predicted timing of the Neolithic Revolution based on the various methods for the main specification. Panel A predicts this timing based on the inverse weighted distance interpolation for $N=16, p=4$ and the entire set of neolithic sites across Europe, North Africa, and the Middle-East, for the region as a whole (Figure 3(a)) and for the French teritory only (Figure 3(b)). Panel B depicts the predicted timing of the Neolithic Revolution for each département, based 


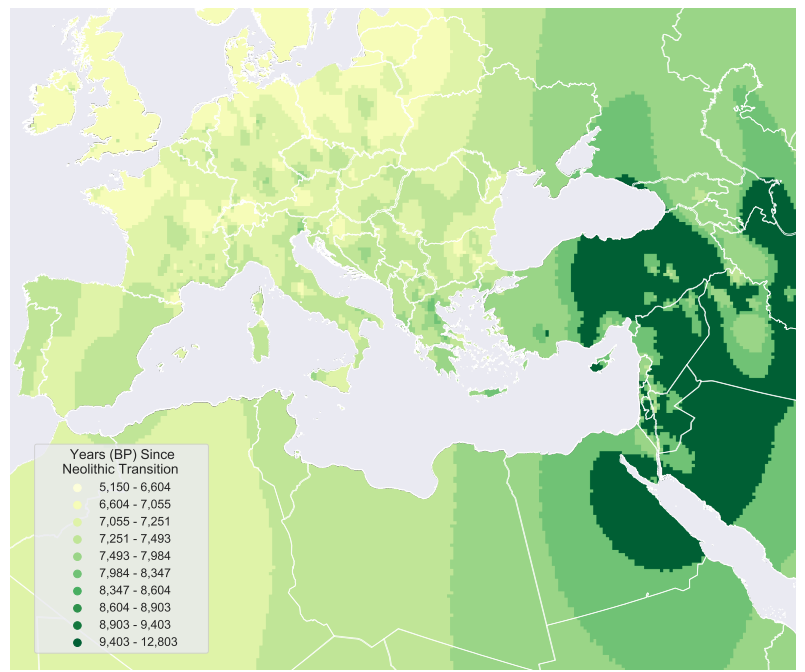

(a) Europe and the Middle East

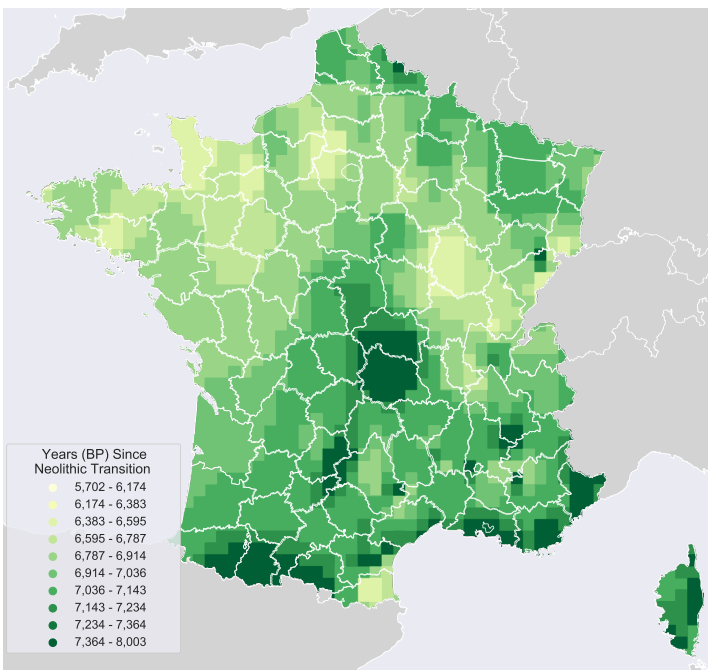

(b) France

Panel A: Predicted Years Since Neolithic Revolution: (interpolation based on all Neolithic sites in the region)

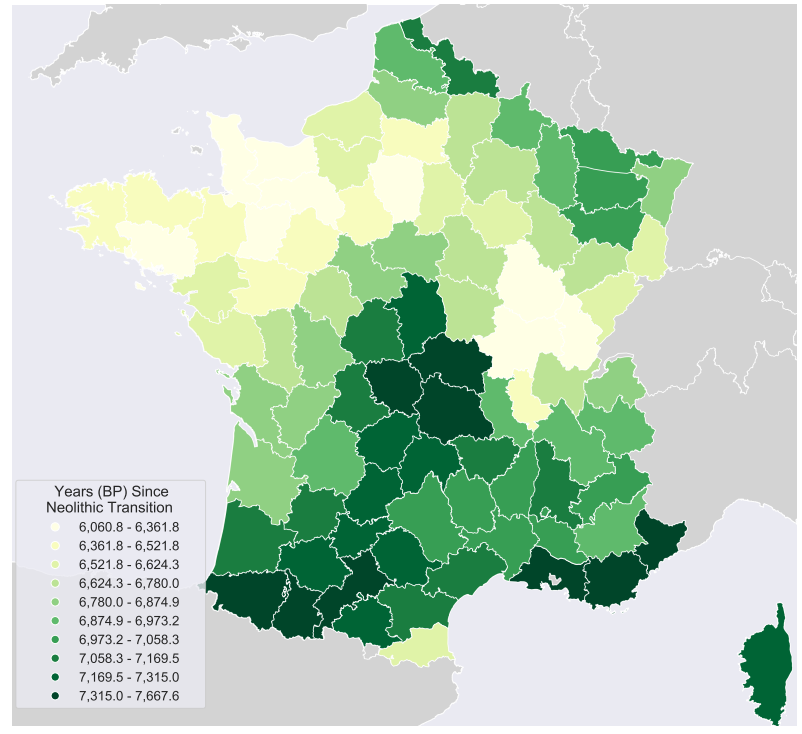

(c) Interpolation based on all Sites

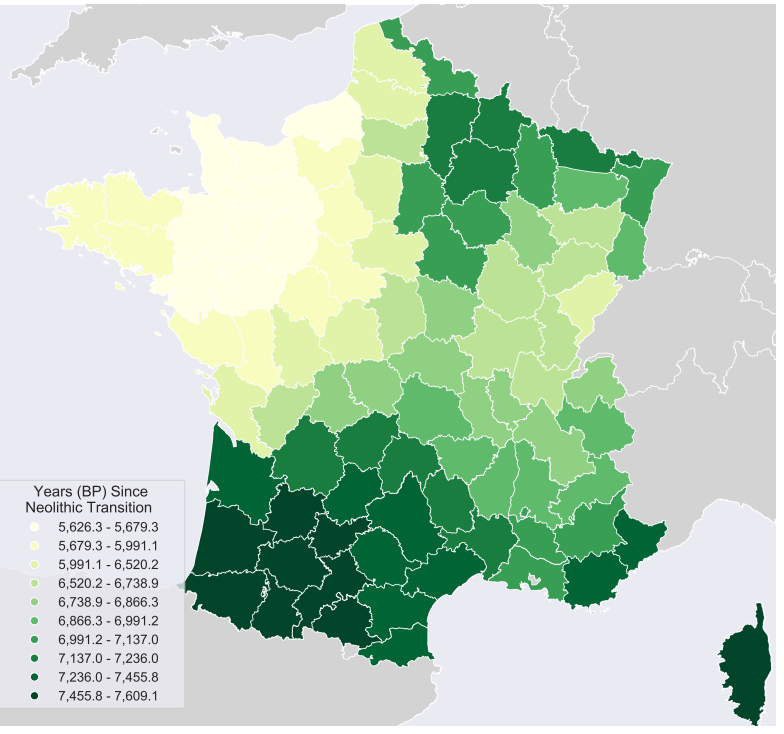

(d) Interpolation based on all Non-French Sites

Panel B: Predicted Years Since Neolithic Revolution Across French départements

Figure 3: Predicted Years Since Neolithic Revolution

on all Neolithic sites (Figure 3(c)), and based on all Non-French Neolithic sites (Figure 3(d)).

The analysis establishes the robustness of the main findings for alternative interpolations, varying the number of neighbors $N=8,16,32,64$, the distance decay parameter $p=1,2$, 4 , excluding sites in France, excluding sites within a buffer of 0,50, $100 \mathrm{kms}$ around France, and excluding sites that are geographically similar to sites in France. 


\subsubsection{Health Outcomes: Life Expectancy, \& Prevalence, Incidence and Mortality Rates from Diseases}

We compile a novel dataset on life expectancy and health outcomes during the pre- and postsecond-epidemiological transition era across French départements and towns.

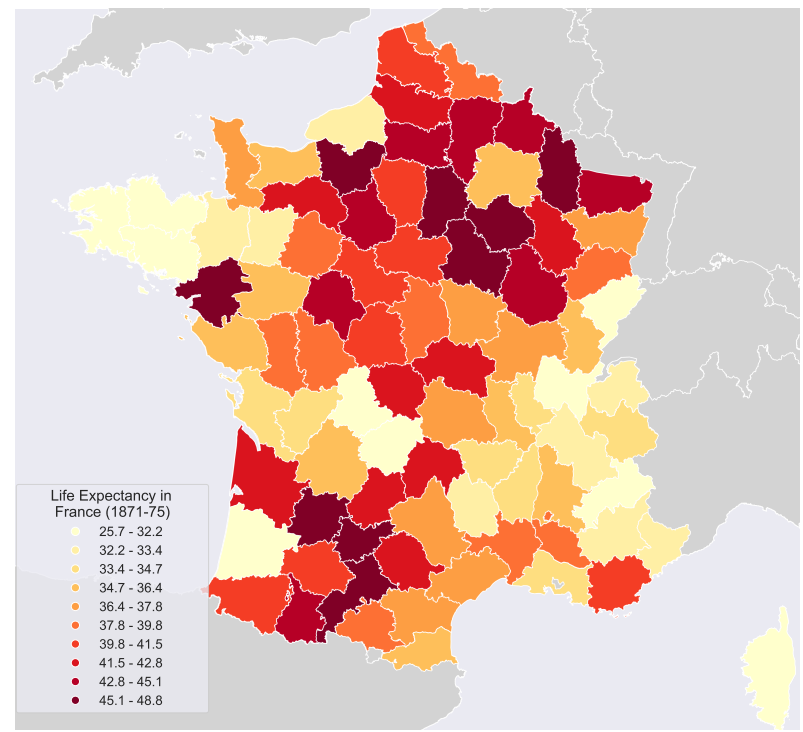

(a) $1871-75$

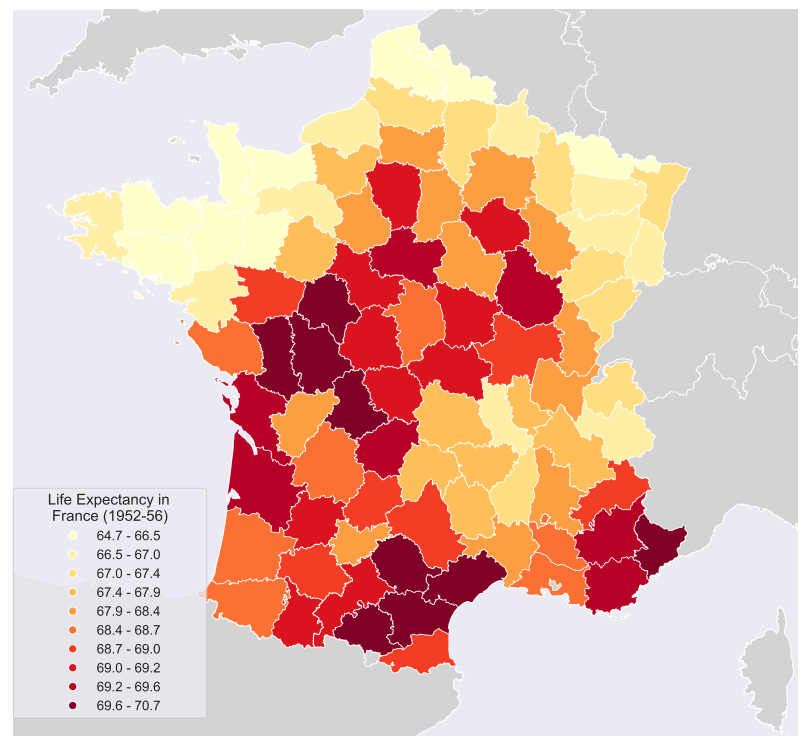

(c) $1952-56$

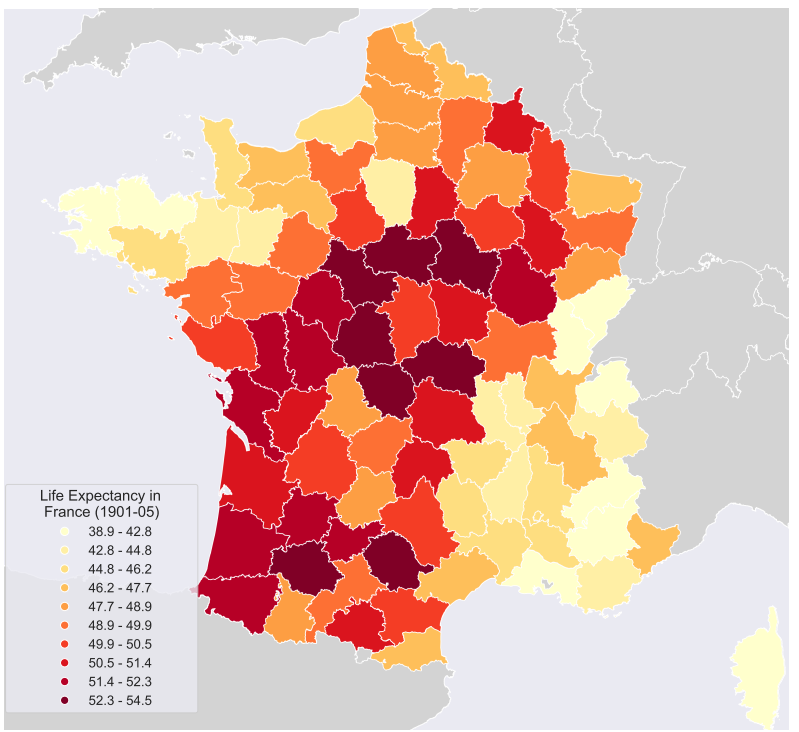

(b) $1901-1905$

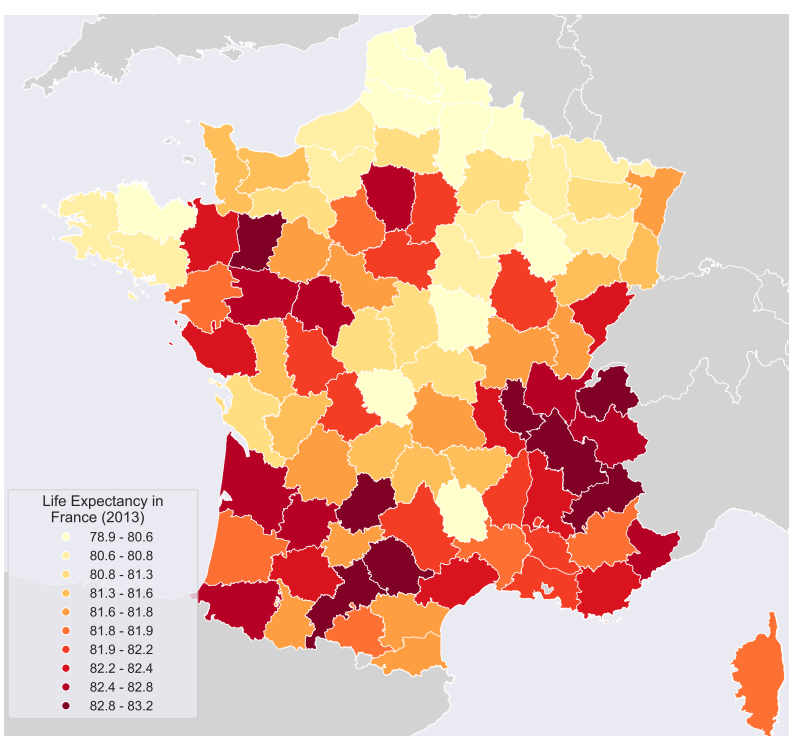

(d) 2013

Figure 4: Life Expectancy in France

Data on life expectancy come from several sources: (i) digitized data on life expectancy prior to the second epidemiological transition available at five year intervals in the 1801-1906 period (Bonneuil, 1997); (ii) data for the inter-war period which we compute from the age distribution in the 
1921, 1931 and 1936 censuses of the French population (Béaur and Marin, 2011; France, 1931, 1936), (iii) data around the epidemiological transition (1952-56) (INSEE, 1964) and (iv) afterwards (1968, 1975, 1982, and the 1990-2013 period) from the French Institute of Statistics (Institut National des Statistiques et des Etudes Economiques - INSEE). Figure 4 depicts the regional distribution of life expectancy for a sample of years before, during, and after the second epidemiological transition.

Data on mortality and morbidity from various causes originate from several sources and methods of aggregation. For the pre-WWI period, we use official statistics (France, 1901) on mortality from different causes across French towns in $1900 .{ }^{15}$ Moreover, due to the lack of systematic and reliable mortality data at the département-level before WWI, ${ }^{16}$ town-level mortality data are aggregated, creating a proxy for each département-level mortality rates. Figure 5 depicts the distribution of mortality rates from (a) all diseases and from (b) all infectious diseases across towns in 1900. For the post-WWII era, the analysis uses data from three sources: the National institute for Demographic Studies (Institut National des Etudes Démographiques - INED) and the Institute for Research and Documentation in Health Economics (Institut de Recherche et de Documentation en Economie de la Santé - IRDES) provide health data at the département level, while the Generation and Gender Programme provides individual level data on health outcomes. Specifically, the Generation and Gender Programme enables us to isolate individuals of French ancestry who lived in the département where they were born at the time of the survey. ${ }^{17}$

\subsection{Empirical Specification}

This section presents the baseline econometric model of the relationship between the time elapsed since the Neolithic Revolution and health outcomes. Specifically, the following empirical specification is initially estimated via ordinary least squares (OLS):

$$
Y_{i}=\beta_{0}+\beta_{1} \widehat{N R}_{i}+\sum_{j} \gamma_{0 j} X_{i j}+\epsilon_{i}
$$

where $\widehat{N R}_{i}$ is the measure of the time elapsed since the Neolithic Revolution based on all Neolithic sites, $Y_{i}$ is a health outcome (e.g., log life expectancy, mortality rate from infectious diseases, or mortality rate from other causes), $X_{i j}$ is a vector of geographical and development confounders and $\epsilon_{i}$ is an error term in département or town $i$.

In view of the potential endogeneity of $\widehat{N R}_{i}$, e.g., due to omitted variables or reverse causality, the proposed instrumental variable strategy is employed and $\widehat{N R}_{i}$ is instrumented by the predicted

\footnotetext{
${ }^{15}$ The towns in our sample are the chefs-lieux de départements and the chefs-lieux d'arrondissement, i.e., the main administrative towns of each département.

${ }^{16}$ Some nosological tables are available in the mid-19th century (see, e.g., Statistique de la France, Tome X, 2ème série, Population, 1855-1857), but these data are not reliable as they only cover a subsample of the total deaths.

${ }^{17}$ The analysis in the post-epidemiological transition era cannot be performed at the town-level, since to the best of our knowledge there does not seem to exist similar accessible town-level data on mortality and morbidity for this period.
} 


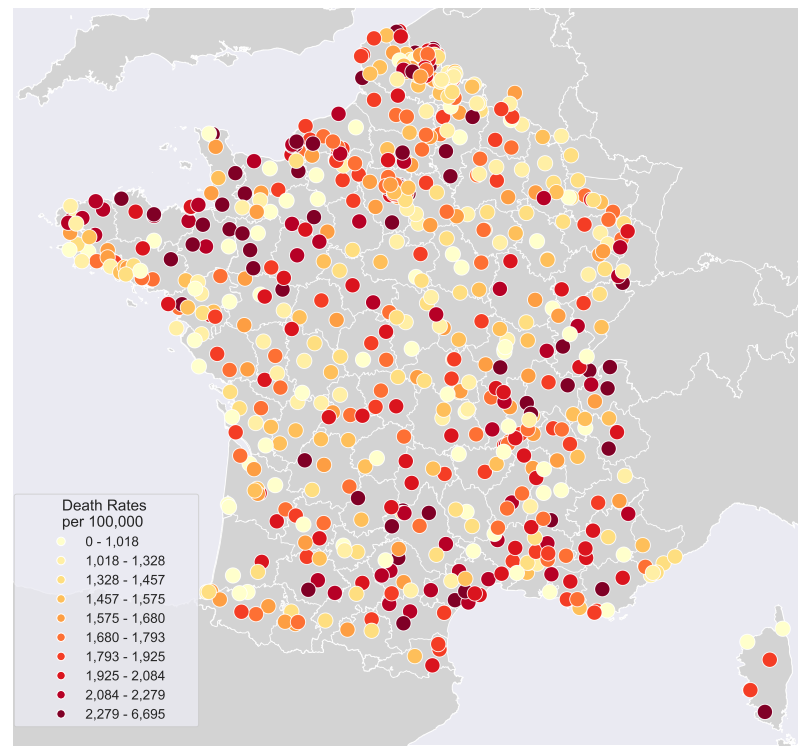

(a) All Diseases

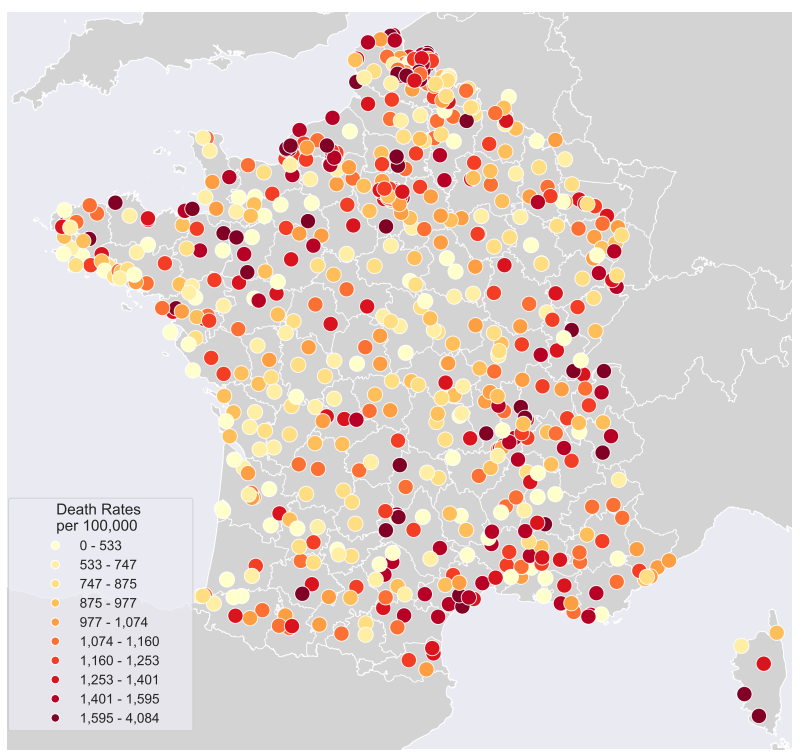

(b) Infectious Diseases

Figure 5: Town Level Mortality in 1900

timing of the Neolithic Revolution excluding French sites $\widehat{N R}_{i}{ }^{N F}$. In particular, the analysis estimates a first-stage regression

$$
\widehat{N R}_{i}=\alpha_{0}+\alpha_{1} \widehat{N R}_{i}^{N F}+\sum_{j} \gamma_{1 j} X_{i j}+\eta_{i}
$$

where $\widehat{N R}_{i}$ and $\widehat{N R}_{i} N F$ are the two measures of predicted timing of the Neolithic Revolution introduced in Section 2.2.1, and $\eta_{i}$ is the error term in département or town $i$.

\section{Findings}

This section analyzes the effect of the time elapsed since the onset of the Neolithic Revolution on life expectancy and other health outcomes across French départements and towns before, during, and after the second epidemiological transition.

\subsection{Life Expectancy Before and After the Second Epidemiological Transition}

\subsubsection{Life Expectancy Before the Second Epidemiological Transition}

This section explores the effect of the Neolithic Revolution on life expectancy across départements before the second epidemiological transition. Columns (1)-(3) of Table 1 show the association between the years elapsed since the territory of a département experienced the Neolithic Revolution and life expectancy in 1871-75, accounting for geographical characteristics and pre-industrial development. Specifically, the analysis accounts for the confounding effect of latitude, which is negatively 
correlated with the timing of the Neolithic Revolution, and is also associated with climatic conditions and development that may have direct effects on life expectancy. Additionally, it accounts for the effect of agricultural and pre-1500CE caloric suitability, which may affect life expectancy through their impact on nutrition or population density (Galor and Özak, 2015, 2016) and could be associated with the adoption of or a comparative advantage in agriculture, thus increasing the potential exposure to disease. Furthermore, the analysis accounts for the effects of climate (average and volatility of temperature and precipitation) as well as elevation and ruggedness, which may affect individuals' incentive to adopt agriculture as well as their health. Moreover, it controls for the effect of pre-industrial mobility and geographical accessibility, which may affect the diffusion of diseases, knowledge, and technologies (Ashraf et al., 2010; Özak, 2010, 2018), and thus may have affected both the transition to the Neolithic and life expectancy. Finally, it accounts for the effect of pre-industrial development as measured by population density in 1700 . The estimated standardized betas of these OLS regressions suggest that a one standard deviation increase in the time since the Neolithic Revolution is associated with about $1 / 5$ of a standard deviation increase in log-life expectancy in 1871.

Table 1: Neolithic Revolution and Life Expectancy (1871-1875)

\begin{tabular}{|c|c|c|c|c|c|c|c|c|c|}
\hline & \multicolumn{9}{|c|}{ Log Life Expectancy (1871-1875) } \\
\hline & \multicolumn{3}{|c|}{ OLS } & \multicolumn{3}{|c|}{ Reduced Form } & \multicolumn{3}{|c|}{ IV } \\
\hline & (1) & $(2)$ & (3) & (4) & (5) & (6) & (7) & (8) & (9) \\
\hline \multirow[t]{6}{*}{ Years Since Neolithic Revolution } & $0.30^{* * *}$ & $0.24^{* *}$ & $0.23^{* *}$ & $0.42^{* * *}$ & $0.46^{* * *}$ & $0.47^{* * *}$ & $0.79 * * *$ & $0.57^{* * *}$ & $0.58^{* * *}$ \\
\hline & $(0.11)$ & $(0.09)$ & $(0.09)$ & $(0.13)$ & $(0.15)$ & $(0.15)$ & $(0.27)$ & $(0.19)$ & $(0.18)$ \\
\hline & {$[0.12]$} & {$[0.08]$} & {$[0.08]$} & {$[0.18]$} & {$[0.13]$} & {$[0.13]$} & {$[0.36]$} & {$[0.19]$} & {$[0.19]$} \\
\hline & $((0.11))$ & $((0.06))$ & $((0.07))$ & $((0.21))$ & $((0.13))$ & $((0.13))$ & $((0.40))$ & $((0.16))$ & $((0.16))$ \\
\hline & {$[[0.01]$} & {$[[0.05]$} & {$[[0.06]$} & {$[[0.10]$} & {$[[0.12]$} & {$[[0.13]$} & {$[[0.17]$} & {$[[0.19]$} & {$[[0.20]$} \\
\hline & $([0.02])$ & $([0.01])$ & $([0.01])$ & $([0.00])$ & $([0.03])$ & $([0.03])$ & $([0.03])$ & $([0.04])$ & $([0.04])$ \\
\hline Geographical Controls & Abs. Lat. & All & All & Abs. Lat. & All & All & Abs. Lat. & All & All \\
\hline Population Density (1700) & No & No & Yes & No & No & Yes & No & No & Yes \\
\hline First-stage F-statistic & & & & & & & 58.72 & 55.77 & 55.12 \\
\hline Adjusted- $R^{2}$ & 0.07 & 0.31 & 0.31 & 0.12 & 0.35 & 0.36 & -0.08 & 0.24 & 0.23 \\
\hline Observations & 86 & 86 & 86 & 86 & 86 & 86 & 86 & 86 & 86 \\
\hline
\end{tabular}

Notes: Standardized coefficients from Ordinary Least Squares (OLS) and Instrumental Variables (IV) regressions. Heteroskedasticity robust standard error estimates are reported in parentheses, spatial auto-correlation corrected standard errors with distance cutoffs at 100, 200,500, and $1000 \mathrm{kms}$. are shown below; *** denotes statistical significance at the $1 \%$ level, ** at the $5 \%$ level, and * at the $10 \%$ level, all for two-sided hypothesis tests.

To give a causal interpretation to our results, we use the instrumental variable strategy discussed in section 2.2.1. Columns (4)-(6) replicate the analysis using $\widehat{N R}^{N F}$ as the main independent variable, i.e., they show the reduced form regression results. The estimated association becomes more significant and implies that a one standard deviation increase in the time since the Neolithic Revolution is associated with 0.47 standard deviations increase in log-life expectancy in 1871. Finally, columns (7)-(9) show the estimated effect based on the instrumental variable regression, 
i.e. by instrumenting $\widehat{N R}$ with $\widehat{N R}^{N F}$. The estimates suggest a quantitatively large and statistically significant effect of the timing of the Neolithic Revolution on life expectancy, which is robust to accounting for geographical confounders and pre-industrial development. The estimated coefficients suggest that a one standard deviation increase in the timing of the Neolithic Revolution increases log life expectancy by 0.58 standard deviations, or equivalently, increases life expectancy by 0.62 standard deviations. ${ }^{18}$

Table 2: Neolithic Revolution and Life Expectancy (1806-1901)

\begin{tabular}{|c|c|c|c|c|c|c|c|c|c|c|c|}
\hline & \multicolumn{11}{|c|}{ Log Life Expectancy } \\
\hline & 1806 & 1811 & 1821 & 1831 & 1841 & 1851 & 1861 & 1871 & 1881 & 1891 & 1901 \\
\hline & (1) & $(2)$ & (3) & (4) & $(5)$ & (6) & (7) & (8) & $(9)$ & $(10)$ & $(11)$ \\
\hline Years Since Neolithic Revolut & $\begin{array}{c}0.50^{* * *} \\
(0.15)\end{array}$ & $\begin{array}{c}0.40 * * * \\
(0.15)\end{array}$ & $\begin{array}{c}0.63^{* * *} \\
(0.20)\end{array}$ & $\begin{array}{c}0.45^{* *} \\
(0.19)\end{array}$ & $\begin{array}{c}0.50^{* * * *} \\
(0.18)\end{array}$ & $\begin{array}{c}0.39 * * \\
(0.16)\end{array}$ & $\begin{array}{c}0.46^{* * *} \\
(0.15)\end{array}$ & $\begin{array}{c}0.58^{* * *} \\
(0.18)\end{array}$ & $\begin{array}{l}-0.02 \\
(0.12)\end{array}$ & $\begin{array}{c}0.42^{* * *} \\
(0.12)\end{array}$ & $\begin{array}{c}0.33^{* *} \\
(0.13)\end{array}$ \\
\hline First-stage F-statistic & 47.11 & 47.11 & 47.11 & 47.11 & 47.11 & 47.11 & 54.66 & 55.12 & 55.12 & 55.12 & 55.12 \\
\hline Adjusted- $R^{2}$ & 0.25 & 0.30 & 0.02 & 0.20 & 0.30 & 0.33 & 0.46 & 0.23 & 0.57 & 0.62 & 0.58 \\
\hline Observations & 86 & 86 & 86 & 86 & 86 & 86 & 89 & 86 & 86 & 86 & 86 \\
\hline Main Geographical Controls & Yes & Yes & Yes & Yes & Yes & Yes & Yes & Yes & Yes & Yes & Yes \\
\hline Population Density (1700) & Yes & Yes & Yes & Yes & Yes & Yes & Yes & Yes & Yes & Yes & Yes \\
\hline
\end{tabular}

Notes: Standardized coefficients from Instrumental Variables (IV) regressions. Heteroskedasticity robust standard error estimates are reported in parentheses; *** denotes statistical significance at the $1 \%$ level, ** at the $5 \%$ level, and * at the $10 \%$ level, all for two-sided hypothesis tests.

These results suggest a robust and large statistically significant effect of the Neolithic Revolution on life expectancy across French départements between 1871-1875. Table 2 demonstrates that similar results hold across the $19^{\text {th }}$ century. In particular, Table 2 replicates the main IV analyses of Table 1 for life expectancy between 1806 and 1901. The results provide further support for the hypothesis that an earlier timing of the Neolithic Revolution had a positive and large statistically significant effect on life expectancy. The only exception is for 1881, when an outbreak of Asiatic cholera increased mortality in the South of France. ${ }^{19}$

A potential concern with these results is that the estimated effect of the years since the Neolithic Revolution on life expectancy may be reflecting development outcomes instead of a more reactive immune system (Diamond, 1997). Tables 3 and 4 are meant to assuage such a concern. In particular, Table 3 explores the effect of the Neolithic Revolution on life expectancy after accounting for various proxies of pre-industrial development. More specifically, the analysis accounts for the effect of population density and urbanization in 1800 , as well as income per capita in 1872 . The inclusion of these proxies of economic development does not affect the estimated effect of the Neolithic Revolution on life expectancy. Moreover, accounting for the existence of a railroad connection to Paris, which may affect development through trade and also affect the exposure to diseases, does not alter the qualitative nature of the results. Similarly, accounting for the composition of

\footnotetext{
${ }^{18}$ In Table B.1 we explore the robustness of this analysis using the subsample of départements for which Neolithic sites in Pinhasi et al. (2005) are available and we obtain qualitatively similar results.

${ }^{19}$ The ports of entry of the cholera outbreak were the southern harbors of Toulon and Marseille (Bray, 1996).
} 
Table 3: Neolithic Revolution, Development and Life Expectancy (1871-1875)

\begin{tabular}{|c|c|c|c|c|c|c|c|}
\hline & \multicolumn{7}{|c|}{ Log Life Expectancy (1871-1875) } \\
\hline & \multicolumn{4}{|c|}{ Development } & \multicolumn{3}{|c|}{ Composition } \\
\hline & $(1)$ & $(2)$ & $(3)$ & $(4)$ & $(5)$ & $(6)$ & $(7)$ \\
\hline Years Since Neolithic Revolution & $\begin{array}{c}0.59 * * * \\
(0.18)\end{array}$ & $\begin{array}{c}0.58^{* * *} \\
(0.17)\end{array}$ & $\begin{array}{c}0.58 * * * \\
(0.17)\end{array}$ & $\begin{array}{c}0.67^{* * *} \\
(0.20)\end{array}$ & $\begin{array}{c}0.65^{* * *} \\
(0.18)\end{array}$ & $\begin{array}{c}0.67^{* * *} \\
(0.19)\end{array}$ & $\begin{array}{c}0.59^{* * *} \\
(0.18)\end{array}$ \\
\hline Population Density (1800) & $\begin{array}{l}-0.11 \\
(0.10)\end{array}$ & & & & & & \\
\hline Urbanization (1800) & & $\begin{array}{l}-0.15^{*} \\
(0.09)\end{array}$ & & & & & \\
\hline GDP per capita $(1872)$ & & & $\begin{array}{c}0.27^{* *} \\
(0.13)\end{array}$ & & & & \\
\hline Railroad Connection to Paris (1870) & & & & $\begin{array}{c}0.36^{* * *} \\
(0.10)\end{array}$ & & & \\
\hline Employment Share in Agriculture (1876) & & & & & $\begin{array}{c}0.16 \\
(0.13)\end{array}$ & & \\
\hline Employment Share in Industry (1876) & & & & & & $\begin{array}{l}-0.18 \\
(0.14)\end{array}$ & \\
\hline Employment Share in Services (1876) & & & & & & & $\begin{array}{l}-0.04 \\
(0.12)\end{array}$ \\
\hline Main Geographical Controls & Yes & Yes & Yes & Yes & Yes & Yes & Yes \\
\hline First-stage F-statistic & 54.75 & 54.76 & 56.02 & 57.80 & 45.10 & 44.99 & 60.81 \\
\hline Adjusted- $R^{2}$ & 0.22 & 0.23 & 0.25 & 0.30 & 0.19 & 0.19 & 0.21 \\
\hline Observations & 85 & 85 & 85 & 85 & 85 & 85 & 85 \\
\hline
\end{tabular}

production between agriculture, industry, and services does not alter the results either.

Moreover, Table 4 accounts for the effect of human capital on life expectancy. In particular, the analysis uses various proxies for human capital around the 1871-1875 period, such as the share of illiterate conscripts, or literate conscripts who did not graduate from high-school, the share of children enrolled in primary schools, and the presence of a university in the département. The results suggest that although human capital and life expectancy are positively associated, the effect of the Neolithic Revolution on life expectancy retains its sign and significance, even after accounting for the impact of Neolithic Revolution on human capital accumulation and its subsequent beneficial effect on life expectancy. Overall, the results of Tables 3 and 4 suggest that the estimated effect of the timing of the Neolithic Revolution does not reflect its effect on economic development, providing indirect support to the hypothesized immunological channel. ${ }^{20}$

\subsubsection{Life Expectancy After the Second Epidemiological Transition}

This section explores the effect of the Neolithic Revolution on life expectancy across départements after the second epidemiological transition. The proposed hypothesis suggests that following the

\footnotetext{
${ }^{20}$ Appendix B shows that similar results are obtained if the 1901-1905 era is considered. The lack of similar data for other periods prevents the analysis to be similarly performed for the full $19^{\text {th }}$ century.
} 
Table 4: Neolithic Revolution, Human Capital and Life Expectancy (1871-1875)

\begin{tabular}{|c|c|c|c|c|c|c|c|}
\hline & \multicolumn{7}{|c|}{ Log Life Expectancy (1871-1875) } \\
\hline & $(1)$ & $(2)$ & $(3)$ & $(4)$ & $(5)$ & $(6)$ & $(7)$ \\
\hline Years Since Neolithic Revolution & $\begin{array}{c}0.49 * * * \\
(0.13)\end{array}$ & $\begin{array}{c}0.58^{* * *} \\
(0.18)\end{array}$ & $\begin{array}{c}0.49^{* * *} \\
(0.13)\end{array}$ & $\begin{array}{c}0.54^{* * *} \\
(0.17)\end{array}$ & $\begin{array}{c}0.48^{* * *} \\
(0.13)\end{array}$ & $\begin{array}{c}0.42^{* * *} \\
(0.14)\end{array}$ & $\begin{array}{c}0.58^{* * *} \\
(0.18)\end{array}$ \\
\hline Illiterate Conscripts (share, 1874) & $\begin{array}{c}-0.55^{* * *} \\
(0.12)\end{array}$ & & & & & & \\
\hline Literate Conscripts (share, Read Only, 1874) & & $\begin{array}{l}-0.03 \\
(0.10)\end{array}$ & & & & & \\
\hline Literate Conscripts (share, no HSG, 1874) & & & $\begin{array}{c}0.54^{* * *} \\
(0.12)\end{array}$ & & & & \\
\hline Literate Conscripts (share, HSG Only, 1874) & & & & $\begin{array}{c}0.18 \\
(0.11)\end{array}$ & & & \\
\hline Literate Conscripts (share, 1874) & & & & & $\begin{array}{c}0.55^{* * *} \\
(0.12)\end{array}$ & & \\
\hline Children Enrolled in Primary Schools (share, 1876) & & & & & & $\begin{array}{c}0.52^{* * *} \\
(0.14)\end{array}$ & \\
\hline University & & & & & & & $\begin{array}{c}0.01 \\
(0.09)\end{array}$ \\
\hline Main Geographical Controls & Yes & Yes & Yes & Yes & Yes & Yes & Yes \\
\hline Population Density (1700) & Yes & Yes & Yes & Yes & Yes & Yes & Yes \\
\hline First-stage F-statistic & 68.56 & 55.12 & 68.76 & 62.88 & 69.89 & 66.65 & 51.81 \\
\hline Adjusted- $R^{2}$ & 0.49 & 0.22 & 0.48 & 0.26 & 0.49 & 0.43 & 0.22 \\
\hline Observations & 86 & 86 & 86 & 86 & 86 & 86 & 86 \\
\hline
\end{tabular}

Notes: Standardized coefficients from Instrumental Variables (IV) regression. Heteroskedasticity robust standard error estimates are reported in parentheses; $* * *$ denotes statistical significance at the $1 \%$ level, ${ }^{* *}$ at the $5 \%$ level, and $*$ at the $10 \%$ level, all for two-sided hypothesis tests.

second epidemiological transition, the Neolithic Revolution should cease to have an effect on life expectancy, as the beneficial effects of an overreactive immune system dissipate due to the introduction of immunization campaigns, antibiotics, and other medical technologies, while the negative effects of an overreactive immune system due to autoimmune disease and inflammatory conditions have not had time to manifest themselves. However, as time passes, the Neolithic Revolution should have a negative effect on life expectancy, as the negative effects of an overreactive immune system outweigh its positive effects.

This section explores the effect of the onset of the Neolithic Revolution on life expectancy across départements after the second epidemiological transition. Table 5 focuses on life expectancy data for the 1952-2013 period such that the empirical specification and controls in all columns are identical to those in Table 1. Panel A establishes that the Neolithic Revolution has no effect on life expectancy in the period 1952-56. The absence of an effect of the Neolithic Revolution on life expectancy in this period supports our hypothesis, as the end of WWII was followed by the introduction of many technologies that made the second epidemiological transition possible. ${ }^{21}$

\footnotetext{
${ }^{21}$ The first half of the $20^{\text {th }}$ century saw the discovery and introduction of many new vaccines and medicines. For instance, new vaccines were discovered for diphtheria (1923), pertussis (1926), tuberculosis (1927), tetanus (1927), and polio (1952). Similarly, new drugs and therapies against bacteria were introduced. For example, Alexander Fleming discovered Penicillin in 1928; Gerhard Domagk developed a chemotherapeutic cure for streptococcus in 1932; and
} 
Table 5: Neolithic Revolution and Life Expectancy (1952-2013)

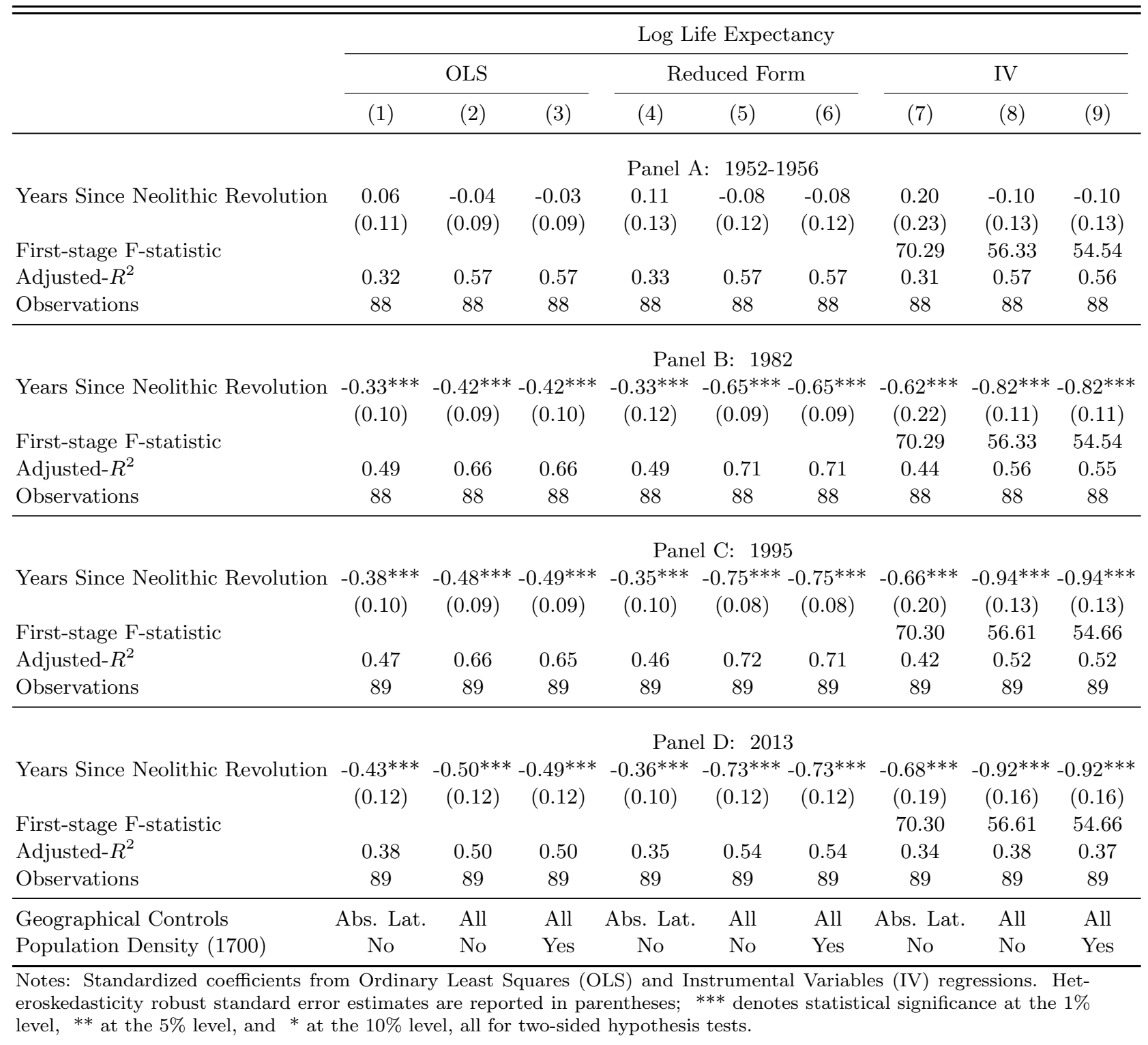

Panel B establishes the negative effect of the onset of the Neolithic Revolution on life expectancy in 1982. Thus, in line our hypothesis, the impact of the Neolithic Revolution on life expectancy has been reversed three decades after the second epidemiological transition, reflecting the preponderance of the negative effects associated with an overreactive immune system over its beneficial ones. The presence of a negative effect of the Neolithic Revolution on life expectancy after the epidemiological transition is further confirmed by the estimated OLS and IV coefficients in Panels C and D, which focuses on the years 1995 and 2000. In particular, after accounting for geographical confounders and pre-industrial development, a one standard deviation increase in the timing of the Neolithic Lloyd Conover discovered Tetracycline in 1955. While many discoveries were made in the early $20^{\text {th }}$ century, their widespread application only took place after WWII. For example, antibiotics only started to be produced and used in large scale in the 1950's once production methods allowed it. 
Revolution decreases life expectancy by 0.92 standard deviations.

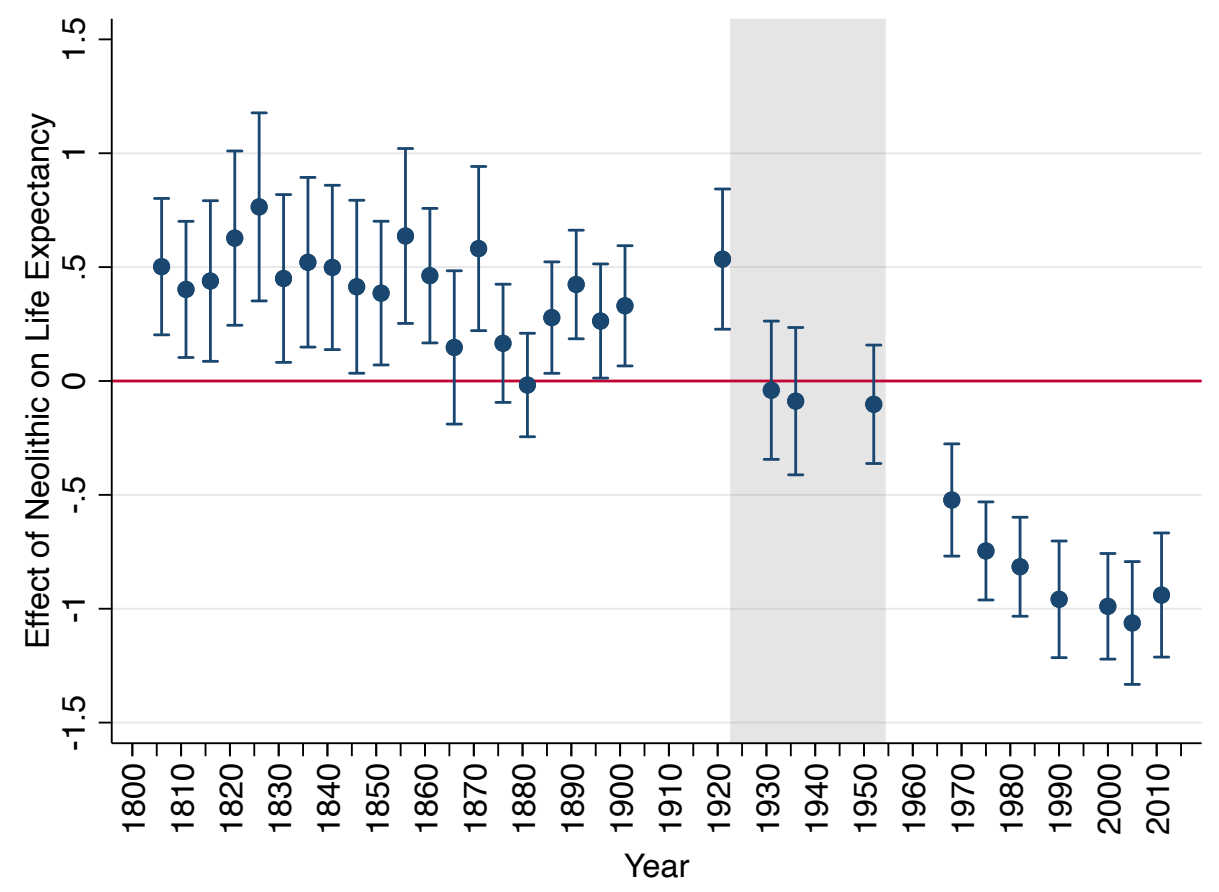

Figure 6: Effect of Neolithic Revolution on Life Expectancy (1806-2013)

Finally, Figure 6 depicts the estimated coefficient for the empirical specification in column (9) of Table 5 for all years between 1806 and 2013 for which there is data. The shaded area highlights the period between 1922 and 1955 when major medical innovations occurred, including the use of insulin to treat diabetes (1922), the discovery of penicillin (1928), development of vaccines against tetanus (1923), diphtheria (1923), whooping cough (1926), tuberculosis (1927), influenza (1945), polio (1955) among other innovations (Hajar, 2015). The figure depicts a clear break during this period: all estimated effects of the Neolithic Revolution on life expectancy before that era are positive without any clear time trend; afterwards all coefficients are negative with a clear trend in the 1952-1990 period, when the coefficient becomes ever more negative. The pattern depicted in Figure 6 provides clear support for the hypothesized double-edged sword effect of the Neolithic Revolution on life expectancy.

\subsection{Mechanisms: Neolithic Revolution and Mortality from Disease}

The previous analyses establish the double-edged sword effect of the Neolithic Revolution on life expectancy. These results suggest that this effect does not reflect the onset of the Neolithic Revolution on economic development but instead support its hypothesized evolutionary effect on the immune system. This section further explores this hypothesis by analyzing the impact of the Neolithic Revolution on mortality from diseases and other causes before and after the epidemiological transition. 


\subsubsection{Mortality from Disease Before the Second Epidemiological Transition}

This section explores the effect of the time elapsed since the Neolithic Revolution on mortality across 593 towns in France before the second epidemiological transition. In particular, it exploits cross-town variations in mortality rates from diseases and other causes in 1900 to identify this effect. Figure 7 depicts the mortality rates from all diseases and from infectious diseases across towns in 1900.

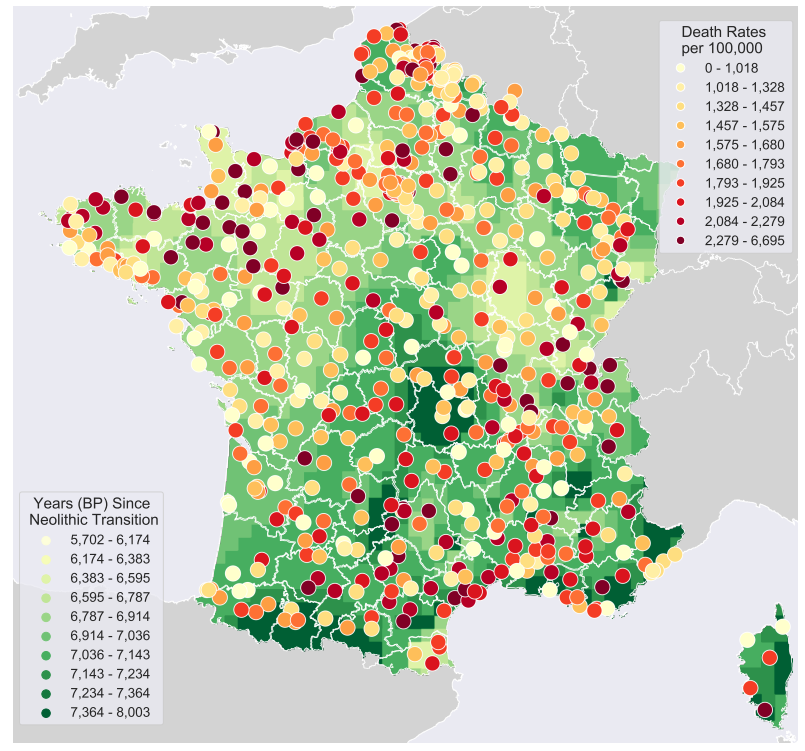

(a) All Diseases

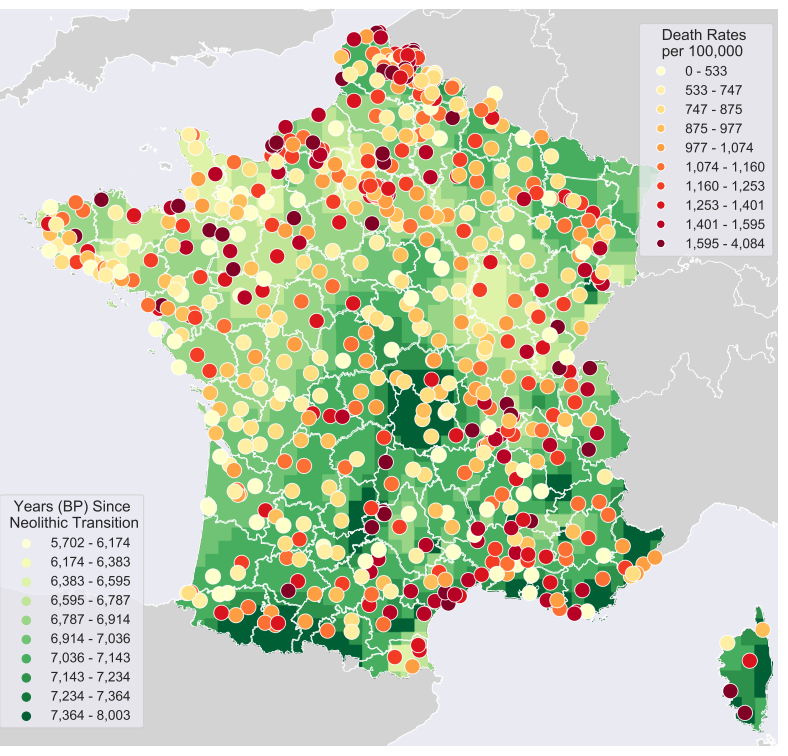

(b) Infectious Diseases

Figure 7: Town Level Mortality in 1900

Table 6 explores the effect of the time elapsed since the Neolithic Revolution on mortality rates from various causes across French towns in 1900. The analysis accounts for geographical characteristics of towns and proxies for their level of development. Moreover, it accounts for the potential correlation among cities by clustering standard errors at the département level. Columns (1)-(2) establish the negative effect of the Neolithic Revolution on mortality rates from all diseases across towns in 1900 (see Table B.13 for OLS and reduced form analyses). In particular, in Column (2) the analysis accounts for the average geographical characteristics 10kms around the town's location. Additionally, it accounts for the size of the town and its distance to Fresnes-sur-Escaut, the village in the North of France which affected the national process of industrialization as one its mines was the location of the first successful industrial use of a steam engine in the country (Franck and Galor, forthcoming). In both columns the estimated effect of the Neolithic Revolution is large, negative and statistically significant. After accounting for all these confounders, the results suggest that a one standard deviation increase in the timing of the Neolithic Revolution is accompanied by a 0.41 standard deviation decrease in mortality from diseases.

Importantly, while 1900 predates the second epidemiological transition and the various novel vaccines and medicines introduced in the first half of the $20^{\text {th }}$ century, it follows major discoveries 
Table 6: Neolithic Revolution and Town-Level Mortality (1900)

\begin{tabular}{|c|c|c|c|c|c|c|c|c|c|c|}
\hline & \multicolumn{10}{|c|}{ Mortality Rate across Towns (1900) } \\
\hline & \multirow{2}{*}{\multicolumn{2}{|c|}{ All Diseases }} & \multirow{2}{*}{\multicolumn{2}{|c|}{ Infectious (Air) }} & \multicolumn{6}{|c|}{ Placebo } \\
\hline & & & & & \multicolumn{2}{|c|}{$\begin{array}{l}\text { Infectious } \\
\text { (Water) }\end{array}$} & \multicolumn{2}{|c|}{ Suicides } & \multicolumn{2}{|l|}{$\begin{array}{l}\text { Violent } \\
\text { Deaths }\end{array}$} \\
\hline & (1) & $(2)$ & (3) & (4) & (5) & (6) & $(7)$ & (8) & (9) & (10) \\
\hline Years Since Neolithic Revolution & $\begin{array}{c}-0.36^{* * *} \\
(0.11)\end{array}$ & $\begin{array}{c}-0.41^{* * *} \\
(0.12)\end{array}$ & $\begin{array}{c}-0.16^{*} \\
(0.08)\end{array}$ & $\begin{array}{c}-0.31^{* * *} \\
(0.10)\end{array}$ & $\begin{array}{c}0.05 \\
(0.19)\end{array}$ & $\begin{array}{l}0.15 \\
(0.15)\end{array}$ & $\begin{array}{l}-0.02 \\
(0.10)\end{array}$ & $\begin{array}{c}0.10 \\
(0.12)\end{array}$ & $\begin{array}{l}-0.13 \\
(0.12)\end{array}$ & $\begin{array}{l}-0.09 \\
(0.09)\end{array}$ \\
\hline Geographical Controls & Abs. Lat. & All & Abs. Lat. & All & Abs. Lat. & All & Abs. Lat. & . All & Abs. Lat. & All \\
\hline Population & No & Yes & No & Yes & No & Yes & No & Yes & No & Yes \\
\hline Distance to Fresnes & No & Yes & No & Yes & No & Yes & No & Yes & No & Yes \\
\hline First-stage F-statistic & 35.02 & 35.70 & 35.02 & 35.70 & 35.02 & 35.70 & 35.02 & 35.70 & 35.02 & 35.70 \\
\hline Adjusted- $R^{2}$ & 0.02 & 0.02 & 0.05 & 0.09 & 0.08 & 0.15 & 0.00 & -0.01 & 0.05 & 0.10 \\
\hline Observations & 593 & 593 & 593 & 593 & 593 & 593 & 593 & 593 & 593 & 593 \\
\hline
\end{tabular}

Notes: Standardized coefficients from Instrumental Variables (IV) regression. Heteroskedasticity robust standard error estimates clustered at the département level are reported in parentheses; *** denotes statistical significance at the $1 \%$ level, ** at the $5 \%$ level, and * at the $10 \%$ level, all for two-sided hypothesis tests.

on the transmission of disease, especially of cholera, which led to major improvements in water and sewage delivery systems during the 1850-1900 period (Preston and Van de Walle, 1978). Thus, the 1900 data allows the analysis to further exploit differences between airborne and waterborne diseases to explore the effect of public health policy on the effect of the Neolithic Revolution. Specifically, the introduction of improved water-supply and sewage systems ought to have a similar effect to the introduction of vaccines and medicines during the second epidemiological transition. In particular, the theory predicts that after the introduction of improved water-supply and sewage systems, but before the second epidemiological transition, the Neolithic Revolution should have a negative effect on mortality from airborne diseases, but should have no significant effect on the mortality from waterborne diseases.

Columns (3)-(6) in Table 6 explore these predictions. In particular, Columns (3)-(4) replicate the main empirical specifications to analyze the effect of the Neolithic Revolution on town-level mortality from all airborne diseases. It establishes the robust negative effect of the Neolithic Revolution on mortality from airborne diseases. The results suggest that a one standard deviation increase in the timing of the Neolithic Revolution decreased mortality from airborne diseases by 0.31 standard deviations (see also Panel B in Table B.13). However, using these same specifications, Columns (5)-(6) show that there is no significant effect of the Neolithic Revolution on mortality from waterborne diseases: the estimated coefficients are small, about $1 / 3-1 / 2$ of the size of the coefficients and have the wrong sign (see also Panel C in Table B.13).

The analysis performs further placebo tests of the theory in Columns (7)-(10) in Table 6. In particular, it explores the effect of the Neolithic Revolution on death causes which are unlikely to be related to illness and thus to the immune system such as suicides and violent deaths. Reassuringly, 
the effect of the Neolithic Revolution on the mortality rates from suicides (Columns (7)-(8)) and violent deaths (Columns (9)-(10)) is statistically insignificant.

Additionally accounting for département-level economic development (Table B.14) or using the départements' average (town-level) mortality rates (Table B.9) does not qualitatively affect the main results. In particular, accounting for département-level economic development increases the effect of the Neolithic Revolution, suggesting that an additional standard deviation in the timing of the Neolithic Revolution decreased the mortality rate from all diseases by 0.69 standard deviations and the mortality rate from airborne diseases by 0.59 standard deviations, but has no significant impact on mortality from waterborne diseases, suicides, or violent deaths. The results provide additional support to the hypothesized positive effect of the Neolithic Revolution on the selection of a overreactive immune system, which prevented disease and mortality, and thus increased life expectancy before the second epidemiological transition.

\subsubsection{Mortality from Disease After the Second Epidemiological Transition}

This section explores the effect of the Neolithic Revolution on mortality and morbidity rates from various causes across départements in France after the second epidemiological transition. In particular, the theory predicts that the timing of the Neolithic Revolution should have a positive effect on the morbidity of and mortality from autoimmune diseases. Additionally, it predicts that the beneficial protective effects of the Neolithic Revolution may persist after the second epidemiological transition for diseases that did not benefit from effective vaccines or antibiotics. Two diseases that exemplify these conditions, and thus are of particular interest for the analysis, are diabetes and tuberculosis (TB). On the one hand, diabetes is one of the most prevalent modern diseases affecting 1 in 11 people according to the World Health Organization. Moreover, this prevalence has increased dramatically in recent decades: the number of people with diabetes has risen from 108 million in 1980 to 422 million in 2014. Importantly, both types I \& II diabetes have been shown to be generated by autoimmune response (Crook, 2004; Gale, 2001; Pickup and Crook, 1998; Syed et al., 2002; Szablewski, 2014; Tsai et al., 2015; Velloso et al., 2013; Bastard et al., 2006). On the other hand, tuberculosis is one of the top 10 causes of death worldwide and is the leading cause of deaths of HIV-positive people. In particular, vaccines against TB have low efficacy and recent strands of TB are multi-drug resistant. ${ }^{22}$

The proposed hypothesis suggests that the Neolithic Revolution should have a positive effect on the morbidity and mortality from diabetes. Panel A in Table 7 explores this prediction across départements. It establishes that the rates of morbidity and mortality from diabetes across départements is positively affected by the timing of the Neolithic Revolution. In particular, it establishes that the timing of the Neolithic Revolution has a positive effect on the number of people per 100,000 individuals with diabetes (prevalence - columns 1-2), the number of new cases of

\footnotetext{
${ }^{22}$ According to the WHO, "The currently used Bacille Calmette-Guérin (BCG) vaccine was developed in 1921 and remains the only available vaccine against TB. Unfortunately, BCG is only partially effective: it provides some protection against severe forms of pediatric TB, but is not completely protective against disease in infants and is unreliable against adult pulmonary TB."
} 
Table 7: Neolithic Revolution and Risk of Diabetes and Tuberculosis (2000-2013)

\begin{tabular}{|c|c|c|c|c|c|c|c|c|c|c|}
\hline \multirow[t]{4}{*}{ Panel A: Autoimmune: } & \multicolumn{10}{|c|}{ Diabetes } \\
\hline & \multicolumn{4}{|c|}{ Morbidity } & \multicolumn{6}{|c|}{ Death Rates per 100,000} \\
\hline & \multicolumn{2}{|c|}{ Prevalence } & \multicolumn{2}{|c|}{ Incidence } & \multicolumn{2}{|c|}{ Total } & \multicolumn{2}{|c|}{ Female } & \multicolumn{2}{|c|}{ Male } \\
\hline & (1) & $(2)$ & $(3)$ & $(4)$ & $(5)$ & (6) & $(7)$ & $(8)$ & $(9)$ & $(10)$ \\
\hline Years Since Neolithic Revolution & $\begin{array}{c}0.61^{* * *} \\
(0.13)\end{array}$ & $\begin{array}{c}0.52^{* * *} \\
(0.13)\end{array}$ & $\begin{array}{c}0.66^{* * *} \\
(0.11)\end{array}$ & $\begin{array}{c}0.60^{* * *} \\
(0.11)\end{array}$ & $\begin{array}{c}0.58 * * * \\
(0.15)\end{array}$ & $\begin{array}{c}0.40^{* * *} \\
(0.12)\end{array}$ & $\begin{array}{c}0.69 * * * \\
(0.17)\end{array}$ & $\begin{array}{c}0.52^{* * *} \\
(0.14)\end{array}$ & $\begin{array}{c}0.43^{* * *} \\
(0.13)\end{array}$ & $\begin{array}{l}0.26^{* *} \\
(0.11)\end{array}$ \\
\hline Main Geographical Controls & Yes & Yes & Yes & Yes & Yes & Yes & Yes & Yes & Yes & Yes \\
\hline Population Density (1700) & Yes & Yes & Yes & Yes & Yes & Yes & Yes & Yes & Yes & Yes \\
\hline GDP per capita & No & Yes & No & Yes & No & Yes & No & Yes & No & Yes \\
\hline First-stage F-statistic & 54.66 & 50.19 & 54.66 & 50.19 & 54.54 & 49.97 & 54.54 & 49.97 & 54.54 & 49.97 \\
\hline Adjusted- $R^{2}$ & 0.49 & 0.54 & 0.55 & 0.58 & 0.40 & 0.63 & 0.35 & 0.60 & 0.42 & 0.62 \\
\hline Observations & 89 & 89 & 89 & 89 & 88 & 88 & 88 & 88 & 88 & 88 \\
\hline \multirow[t]{4}{*}{ Panel B: Ineffective Vaccine: } & \multicolumn{10}{|c|}{ Tuberculosis } \\
\hline & \multicolumn{4}{|c|}{ Morbidity } & \multicolumn{6}{|c|}{ Death Rates per 100,000} \\
\hline & \multicolumn{2}{|c|}{ Prevalence } & \multicolumn{2}{|c|}{ Incidence } & \multicolumn{2}{|c|}{ Total } & \multicolumn{2}{|c|}{ Female } & \multicolumn{2}{|c|}{ Male } \\
\hline & $(1)$ & $(2)$ & $(3)$ & $(4)$ & $(5)$ & $(6)$ & $(7)$ & (8) & $(9)$ & $(10)$ \\
\hline Years Since Neolithic Revolution & $\begin{array}{l}-0.24^{*} \\
(0.14)\end{array}$ & $\begin{array}{c}-0.31^{* *} \\
(0.14)\end{array}$ & $\begin{array}{l}-0.07 \\
(0.14)\end{array}$ & $\begin{array}{l}-0.11 \\
(0.14)\end{array}$ & $\begin{array}{c}-0.37^{* * *} \\
(0.13)\end{array}$ & $\begin{array}{c}-0.41^{* * *} \\
(0.12)\end{array}$ & $\begin{array}{c}-0.56^{* * *} \\
(0.13)\end{array}$ & $\begin{array}{c}-0.58 * * * \\
(0.13)\end{array}$ & $\begin{array}{l}-0.14 \\
(0.16)\end{array}$ & $\begin{array}{l}-0.20 \\
(0.15)\end{array}$ \\
\hline Main Geographical Controls & Yes & Yes & Yes & Yes & Yes & Yes & Yes & Yes & Yes & Yes \\
\hline Population Density (1700) & Yes & Yes & Yes & Yes & Yes & Yes & Yes & Yes & Yes & Yes \\
\hline GDP per capita & No & Yes & No & Yes & No & Yes & No & Yes & No & Yes \\
\hline HIV Controls & Yes & Yes & Yes & Yes & Yes & Yes & Yes & Yes & Yes & Yes \\
\hline First-stage F-statistic & 42.12 & 41.36 & 42.01 & 41.18 & 42.12 & 41.36 & 42.12 & 41.36 & 42.12 & 41.36 \\
\hline Adjusted- $R^{2}$ & 0.60 & 0.61 & 0.73 & 0.73 & 0.45 & 0.44 & 0.38 & 0.36 & 0.34 & 0.35 \\
\hline Observations & 84 & 84 & 82 & 82 & 84 & 84 & 84 & 84 & 84 & 84 \\
\hline
\end{tabular}

Notes: Standardized coefficients from Instrumental Variables (IV) regression. Heteroskedasticity robust standard error estimates are reported in parentheses; $* * *$ denotes statistical significance at the $1 \%$ level, ${ }^{* *}$ at the $5 \%$ level, and $*$ at the $10 \%$ level, all for two-sided hypothesis tests.

diabetes per 100,000 individuals (incidence - columns 3-4), as well as the number of deaths in the population (as a whole or separately for mean and women - columns 5-10) per 100,000 individuals. The estimated effects are large and statistically significant and suggest that after accounting for geographical confounders, pre-industrial and contemporary development, a one standard deviation increase in the timing of the Neolithic Revolution generates a 0.52 standard deviation increase in the prevalence of diabetes, a 0.60 standard deviation increase in the incidence of diabetes, a 0.40 standard deviation increase in the mortality rate from diabetes across the population, a 0.52 standard deviation increase in the mortality rate from diabetes among females, and 0.26 standard deviations increase in the mortality rate from diabetes among males.

Table 8 further explores the predictions of the theory on other autoimmune and inflammatory diseases. In particular, in columns (1)-(7) the analysis establishes the positive effect of the tim- 
Table 8: Neolithic Revolution and Incidence of Disease (2000-2013)

\begin{tabular}{|c|c|c|c|c|c|c|c|c|}
\hline & \multicolumn{8}{|c|}{ Incidence } \\
\hline & \multicolumn{7}{|c|}{ Autoimmune/Inflammation-Mediated Diseases } & \multirow{2}{*}{$\begin{array}{l}\text { Placebo } \\
\text { Mecha- } \\
\text { nical } \\
\text { Heart } \\
\text { Disease }\end{array}$} \\
\hline & $\begin{array}{l}\text { Arterial } \\
\text { ischemic } \\
\text { events }\end{array}$ & $\begin{array}{l}\text { Liver } \\
\text { disease } \\
\& \quad \text { cir- } \\
\text { rhosis }\end{array}$ & $\begin{array}{l}\text { Respi- } \\
\text { ratory } \\
\text { failure }\end{array}$ & $\begin{array}{l}\text { Alzheimer's } \\
\text { disease \& } \\
\text { other de- } \\
\text { mentias }\end{array}$ & $\begin{array}{l}\text { Nephro- } \\
\text { pathy }\end{array}$ & $\begin{array}{l}\text { Ulcerative } \\
\text { colitis } \\
\text { Crohn's } \\
\text { disease }\end{array}$ & $\begin{array}{l}\text { Coronary } \\
\& \text { artery } \\
\text { disease }\end{array}$ & \\
\hline & $(1)$ & $(2)$ & $(3)$ & $(4)$ & $(5)$ & $(6)$ & $(7)$ & (8) \\
\hline Years Since Neolithic Revolution & $\begin{array}{c}0.45^{* * *} \\
(0.17)\end{array}$ & $\begin{array}{c}0.56^{* * *} \\
(0.13)\end{array}$ & $\begin{array}{c}0.43^{* *} \\
(0.20)\end{array}$ & $\begin{array}{c}0.38^{* *} \\
(0.15)\end{array}$ & $\begin{array}{c}0.41^{* *} \\
(0.18)\end{array}$ & $\begin{array}{c}0.98^{* * *} \\
(0.16)\end{array}$ & $\begin{array}{c}0.43^{* * *} \\
(0.16)\end{array}$ & $\begin{array}{c}0.22 \\
(0.16)\end{array}$ \\
\hline Main Geographical Controls & Yes & Yes & Yes & Yes & Yes & Yes & Yes & Yes \\
\hline Population Density (1700) & Yes & Yes & Yes & Yes & Yes & Yes & Yes & Yes \\
\hline GDP per capita (2000-2010) & Yes & Yes & Yes & Yes & Yes & Yes & Yes & Yes \\
\hline First-stage F-statistic & 50.19 & 50.19 & 50.19 & 50.19 & 50.19 & 50.19 & 50.19 & 50.19 \\
\hline Adjusted- $R^{2}$ & 0.36 & 0.52 & 0.50 & 0.28 & 0.41 & 0.39 & 0.24 & 0.40 \\
\hline Observations & 89 & 89 & 89 & 89 & 89 & 89 & 89 & 89 \\
\hline
\end{tabular}

Notes: Standardized coefficients from Instrumental Variables (IV) regression. Heteroskedasticity robust standard error estimates are reported in parentheses; *** denotes statistical significance at the $1 \%$ level, ** at the $5 \%$ level, and * at the $10 \%$ level, all for two-sided hypothesis tests.

ing of the Neolithic Revolution on arterial ischemic events, liver disease \& cirrhosis, respiratory failure, Alzheimer's disease \& other dementias, nephropathy, ulcerative colitis \& Crohn's disease, and coronary artery disease. These diseases have been associated with autoimmune responses or inflammatory conditions, which the theory predicts should increase in regions that experienced an earlier onset of the Neolithic Revolution. ${ }^{23}$ In line with this prediction, the estimated effect of the timing of the Neolithic Revolution is large, positive and statistically significant. In particular, the results suggest that a one standard deviation increase in the timing of the Neolithic Revolution increases the incidence of ulcerative colitis and Crohn's disease by 0.98 standard deviations. Additionally, in column (8) the analysis explores the effect of the Neolithic Revolution on the incidence of mechanical heart disease. This serves as a placebo test, since this type of disease is mechanical by nature and unrelated to the immune system. Reassuringly, the estimated effect is about half the size and not statistically significant, suggesting that the Neolithic Revolution is not associated with this diseases which is not mediated by the immune system.

Panel B in Table 7 explores the second prediction of the theory, namely that the beneficial effect of the Neolithic Revolution may persist after the second epidemiological transition for diseases that did not benefit from effective vaccines or antibiotics. In particular, it replicates the analysis of Panel A in order to explore the effect of the Neolithic Revolution on tuberculosis (TB), but accounts for HIV mortality and morbidity, as HIV tends to be associated with TB in the contemporary era.

\footnotetext{
${ }^{23}$ For instance, Crohn's disease (CD) risk variants have been shown to be strongly selected by interaction with pathogens (Cagliani et al., 2013). Similarly, alleles associated with increased risk of Alzheimer's disease show strong signals of selection and involvement immune cell regulation (Raj et al., 2012).
} 
Although the analysis does not find a significant effect of the timing of the Neolithic Revolution on the incidence of TB across départements, it establishes a significant negative effect of the Neolithic Revolution on the prevalence of TB and well as total and female mortality rates. ${ }^{24}$

The analysis provides further support for the hypothesis by performing various placebo tests. Table 9 thus explores the effect of the Neolithic Revolution on the mortality rate from causes which are not likely to be connected to disease (see also Tables B.11 and B.12). Reassuringly, it shows that the Neolithic Revolution does not have any significant effect on causes of deaths which are not mediated by the immune system such as suicides, alcohol abuse, accidents, and falls.

Table 9: Neolithic Revolution and Deaths from Non-Immune Mediated or External Causes (2000-2013)

\begin{tabular}{|c|c|c|c|c|c|c|c|c|c|c|c|c|}
\hline & \multicolumn{12}{|c|}{ Non-Immune Mediated or External Causes (Death Rates per 100,000) } \\
\hline & \multicolumn{3}{|c|}{ Suicides } & \multicolumn{3}{|c|}{ Alcohol Abuse } & \multicolumn{3}{|c|}{ Accidents } & \multicolumn{3}{|c|}{ Falls } \\
\hline & All & Female & Male & All & Female & Male & All & Female & Male & All & Female & Male \\
\hline & $(1)$ & $(2)$ & $(3)$ & $(4)$ & $(5)$ & $(6)$ & $(7)$ & $(8)$ & $(9)$ & $(10)$ & $(11)$ & $(12)$ \\
\hline \multirow[t]{2}{*}{ Years Since Neolithic Revolution } & -0.07 & -0.04 & -0.09 & -0.06 & 0.19 & -0.12 & -0.08 & -0.04 & -0.10 & -0.24 & -0.26 & -0.20 \\
\hline & $(0.15)$ & $(0.16)$ & $(0.14)$ & $(0.12)$ & $(0.14)$ & $(0.12)$ & $(0.15)$ & $(0.16)$ & $(0.14)$ & $(0.17)$ & $(0.19)$ & $(0.15)$ \\
\hline Main Geographical Controls & Yes & Yes & Yes & Yes & Yes & Yes & Yes & Yes & Yes & Yes & Yes & Yes \\
\hline Population Density (1700) & Yes & Yes & Yes & Yes & Yes & Yes & Yes & Yes & Yes & Yes & Yes & Yes \\
\hline GDP per capita (2000-2010) & Yes & Yes & Yes & Yes & Yes & Yes & Yes & Yes & Yes & Yes & Yes & Yes \\
\hline First-stage F-statistic & 49.97 & 49.97 & 49.97 & 50.19 & 50.19 & 50.19 & 50.19 & 50.19 & 50.19 & 49.97 & 49.97 & 49.97 \\
\hline Adjusted- $R^{2}$ & 0.58 & 0.49 & 0.61 & 0.53 & 0.46 & 0.52 & 0.58 & 0.48 & 0.61 & 0.47 & 0.32 & 0.53 \\
\hline Observations & 88 & 88 & 88 & 89 & 89 & 89 & 89 & 89 & 89 & 88 & 88 & 88 \\
\hline
\end{tabular}

Notes: Standardized coefficients from Instrumental Variables (IV) regression. Heteroskedasticity robust standard error estimates are reported in parentheses; *** denotes statistical significance at the $1 \%$ level, ** at the $5 \%$ level, and * at the $10 \%$ level, all for two-sided hypothesis tests.

Finally, we employ individual level data to explore the effect of the Neolithic on contemporary health outcomes. Table 10 provides regression results using individual data on health from the 2005 Generation and Gender Programme that account for individual level controls (i.e., age, gender, education, marital status, and number of children). In line with the proposed hypothesis, Table 10 establishes that individuals in départements that experienced the Neolithic Revolution earlier are more likely to report a negative assessment of their general health status and, specifically, more likely to report that their health is neither good nor excellent. In addition, those individuals are more likely to report that they suffer from a chronic illness and/or from a disability.

\section{Conclusion}

This research advances the hypothesis and establishes empirically that the onset of the Neolithic Revolution and the associated rise in infectious diseases triggered a process of adaptation that ex-

\footnotetext{
${ }^{24}$ Table B.10 replicates the analysis without accounting for HIV. The results are similar, although quantitively a bit smaller. These results are less robust, which may reflect the confounding effect of HIV in the contemporary era.
} 
Table 10: Neolithic Revolution and Individual Health Outcomes

\begin{tabular}{|c|c|c|c|c|c|c|c|c|}
\hline & \multicolumn{8}{|c|}{ Individual Health Outcomes } \\
\hline & \multicolumn{2}{|c|}{$\begin{array}{l}\text { Worse General } \\
\text { Health Status }\end{array}$} & \multicolumn{2}{|c|}{$\begin{array}{c}\text { Health Not } \\
\text { Good/Excellent }\end{array}$} & \multicolumn{2}{|c|}{ Chronic Illness } & \multicolumn{2}{|c|}{ Disability } \\
\hline & $(1)$ & $(2)$ & $(3)$ & $(4)$ & $(5)$ & $(6)$ & $(7)$ & $(8)$ \\
\hline Years Since Neolithic Revolution & $\begin{array}{c}0.06^{* * *} \\
(0.02)\end{array}$ & $\begin{array}{c}0.05^{* * *} \\
(0.02)\end{array}$ & $\begin{array}{c}0.07 * * * \\
(0.02)\end{array}$ & $\begin{array}{c}0.06^{* * *} \\
(0.01)\end{array}$ & $\begin{array}{c}0.05^{* * *} \\
(0.02)\end{array}$ & $\begin{array}{c}0.04^{* * *} \\
(0.02)\end{array}$ & $\begin{array}{c}0.03^{* *} \\
(0.02)\end{array}$ & $\begin{array}{c}0.03 \\
(0.02)\end{array}$ \\
\hline Geographical Controls & Yes & Yes & Yes & Yes & Yes & Yes & Yes & Yes \\
\hline Individual Controls & No & Yes & No & Yes & No & Yes & No & Yes \\
\hline First-stage F-statistic & 161.11 & 161.33 & 161.11 & 161.33 & 161.11 & 161.33 & 161.11 & 161.33 \\
\hline Adjusted- $R^{2}$ & 0.01 & 0.16 & 0.01 & 0.14 & 0.00 & 0.09 & 0.01 & 0.10 \\
\hline Observations & 7607 & 7607 & 7607 & 7607 & 7607 & 7607 & 7607 & 7607 \\
\hline
\end{tabular}

Notes: Standardized coefficients from Instrumental Variables (IV) regressions. Heteroskedasticity robust standard error estimates clustered at the département of residence are reported in parentheses; ${ }^{*} * *$ denotes statistical significance at the $1 \%$ level, ** at the $5 \%$ level, and * at the $10 \%$ level, all for two-sided hypothesis tests.

panded the prevalence of hyperactive immune systems, reducing mortality from infectious diseases while increasing the propensity for autoimmune and inflammatory diseases. Exploiting an exogenous source of variation in the onset of the Neolithic Revolution across French regions, the analysis identifies the impact of these conflicting forces and their beneficial effects on life expectancy before the second epidemiological transition and their adverse effects thereafter. The results highlight the interaction between two major technological events in human history: the Neolithic Revolution and the Second Epidemiological Transition. Although separated by millennia, their persistent effects are interdependent.

The findings also suggest that in treating patients that suffer from autoimmune diseases, inflammation, and potentially hyperactive immune response, identifying their ancestral origin, and their ancestral timing of the Neolithic Revolution, could provide a vital indicator for a hyperactive immune response that may help during medical treatments. This classification may be used to justify an earlier treatment with anti-inflammatory drugs.

\section{References}

Allen, R. C. (1997). Agriculture and the origins of the state in ancient egypt, Explorations in Economic History 34(2): 135-154.

Althabe, G. (1965). Changements sociaux chez les pygmées baka de l'est-cameroun, Cahiers d'études africaines pp. 561-592.

Anderson, R. M. and May, R. M. (1991). Infectious diseases of humans: dynamics and control, Oxford University Press, Oxford.

Armelagos, G. J. and Barnes, K. (1999). The evolution of human disease and the rise of allergy: Epidemiological transitions, Medical Anthropology 18(2): 187-213. 
Armelagos, G. J., Goodman, A. H. and Jacobs, K. H. (1991). The origins of agriculture: Population growth during a period of declining health, Population and environment 13(1): 9-22.

Ashraf, Q., Galor, O. and Özak, Ö. (2010). Isolation and development, Jourmal of the European Economic Association 8(2-3): 401-412.

Atkinson, Q. D. and Whitehouse, H. (2011). The cultural morphospace of ritual form: Examining modes of religiosity cross-culturally, Evolution and Human Behavior 32(1): 50-62.

Barreiro, L. B. and Quintana-Murci, L. (2010). From evolutionary genetics to human immunology: how selection shapes host defence genes, Nature Reviews Genetics 11(1): 17.

Bastard, J.-P., Maachi, M., Lagathu, C., Kim, M. J., Caron, M., Vidal, H., Capeau, J. and Feve, B. (2006). Recent advances in the relationship between obesity, inflammation, and insulin resistance, European cytokine network 17(1): 4-12.

Béaur, G. and Marin, B. (2011). La statistique générale de la france, Technical report.

Bellwood, P. S. (2005). First Farmers: the origins of agricultural societies, Blackwell Pub., Malden, MA.

Bocquet-Appel, J.-P. (2011). When the world's population took off: the springboard of the neolithic demographic transition, Science 333(6042): 560-561.

Bocquet-Appel, J. P. and Bar-Yosef, O. (2008). The neolithic demographic transition and its consequences, 1st ed edn, Springer, New York.

Bonneuil, N. (1997). Transformation of the French Demographic Landscape, 1806-1906, Clarendon Press, Oxford, UK.

Bray, R. S. (1996). Armies of pestilence: the effects of pandemics on history, Lutterworth, Cambridge.

Cagliani, R., Pozzoli, U., Forni, D., Cassinotti, A., Fumagalli, M., Giani, M., Fichera, M., Lombardini, M., Ardizzone, S., Asselta, R. et al. (2013). Crohn's disease loci are common targets of protozoa-driven selection, Molecular biology and evolution 30(5): 1077-1087.

Childe, V. G. (1951). Man makes himself, A Mentor book, 64, rev edn, New American Library, New York.

Claessen, H. J. M. and Skalník, P. (1978). The Early state, Mouton, The Hague.

Cochran, G. and Harpending, H. (2009). The 10,000 year explosion: how civilization accelerated human evolution, Basic Books, New York.

Cohen, M. N., Armelagos, G. J. and Larsen, C. S. (2013). Paleopathology at the origins of agriculture, Bioarchaeological interpretations of the human past: local, regional, and global perspectives, University Press of Florida, Gainesville.

Cohen, M. N. and Crane-Kramer, G. M. M. (2007). Ancient health: skeletal indicators of agricultural and economic intensification, Bioarchaeological interpretations of the human past, University Press of Florida, Gainesville.

Conley, T. (1999). Gmm estimation with cross sectional dependence, Journal of Econometrics 92(1): $1-45$. 
Corona, E., Dudley, J. T. and Butte, A. J. (2010). Extreme evolutionary disparities seen in positive selection across seven complex diseases, PLoS One 5(8): e12236.

Crook, M. (2004). Type 2 diabetes mellitus: a disease of the innate immune system? an update, Diabetic Medicine 21(3): 203-207.

Diamond, J. (2002). Evolution, consequences and future of plant and animal domestication, Nature 418(6898): 700 .

Diamond, J. M. (1997). Guns, germs, and steel: the fates of human societies, 1st ed edn, W.W. Norton \& Co., New York.

Dobson, A. P. and Carper, E. R. (1996). Infectious diseases and human population history, Bioscience 46(2): 115-126.

France (1901). Direction de l'Assistance et de l'Hygiène Publiques: Statistique Sanitaire des Villes de France et d'Algérie, Imprimerie Nationale, Paris.

France (1931). Direction de la Statistique Générale: Annuaire Statistique 1931, Imprimerie Nationale, Paris.

France (1936). Direction de la Statistique Générale: Annuaire Statistique 1936, Imprimerie Nationale, Paris.

Franck, R. and Galor, O. (forthcoming). Technology-skill complementarity in early phases of industrialization, Economic Journal -(-):-.

Gale, E. A. (2001). The discovery of type 1 diabetes, Diabetes 50(2): 217-226.

Galor, O. and Özak, Ö. (2015). Land productivity and economic development: Caloric suitability vs. agricultural suitability, SMU Working Paper Series .

Galor, O. and Özak, Ö. (2016). The agricultural origins of time preference, American Economic Review 106(10): 3064-3103.

Galor, O., Özak, Ö. and Sarid, A. (2018). Geographical roots of the coevolution of cultural and linguistic traits, Technical report, National Bureau of Economic Research.

Hajar, R. (2015). History of medicine timeline, Heart views: the official journal of the Gulf Heart Association 16(1): 43.

Hofmanová, Z., Kreutzer, S., Hellenthal, G., Sell, C., Diekmann, Y., Díez-del Molino, D., van Dorp, L., López, S., Kousathanas, A., Link, V. et al. (2016). Early farmers from across europe directly descended from neolithic aegeans, Proceedings of the National Academy of Sciences 113(25): 6886-6891.

INSEE (1964). Donnnés de démographie régionale 1954 - Etudes Démographiques 8, Imprimerie Nationale, Paris.

Karlsson, E. K., Kwiatkowski, D. P. and Sabeti, P. C. (2014). Natural selection and infectious disease in human populations, Nature Reviews Genetics 15(6): 379.

Kohler, T. A., Smith, M. E., Bogaard, A., Feinman, G. M., Peterson, C. E., Betzenhauser, A., Pailes, M., Stone, E. C., Prentiss, A. M., Dennehy, T. J. et al. (2017). Greater post-neolithic wealth disparities in eurasia than in north america and mesoamerica, Nature 551(7682): 619. 
Laland, K. N., Odling-Smee, J. and Myles, S. (2010). How culture shaped the human genome: bringing genetics and the human sciences together, Nature Reviews Genetics 11(2): 137.

Lawn, S. D. and Zumla, A. I. (2011). Tuberculosis, The Lancet 378(9785): 57-72.

Lazaridis, I., Nadel, D., Rollefson, G., Merrett, D. C., Rohland, N., Mallick, S., Fernandes, D., Novak, M., Gamarra, B., Sirak, K. et al. (2016). Genomic insights into the origin of farming in the ancient near east, Nature 536(7617): 419.

Luca, S. and Mihaescu, T. (2013). History of bcg vaccine., Maedica 8(1): 53-58.

Mathieson, I., Lazaridis, I., Rohland, N., Mallick, S., Patterson, N., Roodenberg, S. A., Harney, E., Stewardson, K., Fernandes, D., Novak, M. et al. (2015). Genome-wide patterns of selection in 230 ancient eurasians, Nature 528(7583): 499-503.

McNeill, W. H. (1989). Plagues and people, Anchor Books, New York.

Menozzi, P. and Cavalli-Sforza, L. L. (1993). Demic expansions and human evolution, Science 259(5095): 639-646.

Nielsen, R., Akey, J. M., Jakobsson, M., Pritchard, J. K., Tishkoff, S. and Willerslev, E. (2017). Tracing the peopling of the world through genomics, Nature 541(7637): 302.

Özak, Ö. (2010). The voyage of homo-economicus: Some economic measures of distance.

Özak, Ö. (2018). Distance to the pre-industrial technological frontier and economic development, Journal of Economic Growth 23(2): 175-221.

Pickup, J. and Crook, M. (1998). Is type ii diabetes mellitus a disease of the innate immune system?, Diabetologia 41(10): 1241-1248.

Pinhasi, R., Fort, J. and Ammerman, A. J. (2005). Tracing the origin and spread of agriculture in europe, PLoS biology 3(12): 2220.

Preston, S. H. and Van de Walle, E. (1978). Urban french mortality in the nineteenth century, Population studies 32(2): 275-297.

Raj, T., Shulman, J. M., Keenan, B. T., Chibnik, L. B., Evans, D. A., Bennett, D. A., Stranger, B. E. and De Jager, P. L. (2012). Alzheimer disease susceptibility loci: evidence for a protein network under natural selection, The American Journal of Human Genetics 90(4): 720-726.

Skoglund, P., Malmström, H., Raghavan, M., Storå, J., Hall, P., Willerslev, E., Gilbert, M. T. P., Götherström, A. and Jakobsson, M. (2012). Origins and genetic legacy of neolithic farmers and hunter-gatherers in europe, Science 336(6080): 466-469.

Sokal, R. R., Oden, N. L. and Wilson, C. (1991). Genetic evidence for the spread of agriculture in europe by demic diffusion, Nature 351(6322): 143.

Steckel, R. H. and Rose, J. C. (2002). The backbone of history: health and nutrition in the Western Hemisphere, Cambridge University Press, Cambridge.

Syed, M., Barinas-Mitchell, E., Pietropaolo, S., Zhang, Y., Henderson, T., Kelley, D., Korytkowski, M., Donahue, R., Tracy, R., Trucco, M. et al. (2002). Is type 2 diabetes a chronic inflammatory/autoimmune disease?, Diabetes, nutrition \& metabolism 15(2): 68-83.

Szablewski, L. (2014). Role of immune system in type 1 diabetes mellitus pathogenesis, International immunopharmacology 22(1): 182-191. 
Tsai, S., Clemente-Casares, X., Revelo, X. S., Winer, S. and Winer, D. A. (2015). Are obesityrelated insulin resistance and type 2 diabetes autoimmune diseases?, Diabetes 64(6): 1886-1897.

Turchin, P., Currie, T. E., Turner, E. A. and Gavrilets, S. (2013). War, space, and the evolution of old world complex societies, Proceedings of the National Academy of Sciences 110(41): 1638416389.

Turchin, P., Whitehouse, H., Korotayev, A., Francois, P., Hoyer, D., Peregrine, P., Feinman, G., Spencer, C., Kradin, N. and Currie, T. E. (2018). Evolutionary pathways to statehood: Old theories and new data, Technical report.

Velasquez-Manoff, M. (2012). An epidemic of absence: a new way of understanding allergies and autoimmune diseases, 1st scribner hardcover ed edn, Scribner, New York, NY.

Velloso, L. A., Eizirik, D. L. and Cnop, M. (2013). Type 2 diabetes mellitus - an autoimmune disease?, Nat Rev Endocrinol 9(12): 750-755.

Voight, B. F., Kudaravalli, S., Wen, X. and Pritchard, J. K. (2006). A map of recent positive selection in the human genome, PLoS biology 4(3): e72.

Wang, E. T., Kodama, G., Baldi, P. and Moyzis, R. K. (2006). Global landscape of recent inferred darwinian selection for homo sapiens, Proceedings of the National Academy of Sciences 103(1): 135-140.

Wolfe, N. D., Dunavan, C. P. and Diamond, J. (2007). Origins of major human infectious diseases, Nature 447(7142): 279-283. 


\section{Appendix (Online Publication Only)}

\section{A Data Sources and Summary Statistics}

\section{A.1 Data Sources}

\section{A.2 Summary Statistics}

Table A.1: Summary Statistics on Base Sample Town Level Analysis

\begin{tabular}{lccccc}
\hline \hline & Mean & Std & Min & Max & N \\
\hline Mortality All Diseases & 1763.78 & $(527.60)$ & 219.98 & 6694.56 & 593 \\
Mortality Infectious Diseases (Airborne) & 454.84 & $(218.62)$ & 34.41 & 1860.14 & 593 \\
Mortality Infectious Diseases (Waterborne) & 205.06 & $(164.96)$ & 0.00 & 1305.44 & 593 \\
Violent Deaths & 46.37 & $(37.09)$ & 0.00 & 257.03 & 593 \\
Suicides & 22.68 & $(24.54)$ & 0.00 & 283.49 & 593 \\
Cerebral Ischemia & 40.55 & $(50.53)$ & 0.00 & 531.91 & 593 \\
Tuberculosis (Pulmonary) & 210.86 & $(129.68)$ & 0.00 & 1103.71 & 593 \\
Tuberculosis (Other) & 50.92 & $(61.94)$ & 0.00 & 823.98 & 593 \\
mortalityrate_broncho & 351.29 & $(170.40)$ & 0.00 & 957.93 & 593 \\
Cancer Tumors & 93.87 & $(63.88)$ & 0.00 & 354.36 & 593 \\
Cerebral Congestion and Hemmorrages & 133.49 & $(88.61)$ & 0.00 & 666.39 & 593 \\
Heart Disease & 173.20 & $(110.25)$ & 0.00 & 816.99 & 593 \\
Years Since Neolithic Revolution & 6692.11 & $(378.57)$ & 5810.54 & 7893.53 & 593 \\
Caloric Suitability Index (pre-1500CE) & 8663.88 & $(920.45)$ & 900.42 & 10306.17 & 593 \\
Latitude & 47.23 & $(2.28)$ & 41.62 & 50.78 & 593 \\
Agricultural Suitability & 0.78 & $(0.19)$ & 0.01 & 1.00 & 593 \\
Caloric Suitability (pre-1500CE) & 8710.09 & $(720.02)$ & 4502.08 & 10306.17 & 593 \\
Elevation & 222.14 & $(255.34)$ & 6.24 & 1973.45 & 593 \\
Ruggedness & 89.96 & $(106.05)$ & 14.57 & 585.35 & 593 \\
Precipitation (Avg.) & 66.03 & $(11.98)$ & 48.94 & 128.84 & 593 \\
Precipitation Volatility & 34.58 & $(7.54)$ & 24.27 & 70.31 & 593 \\
Temperature (Avg.) & 10.86 & $(1.43)$ & 3.55 & 14.45 & 593 \\
Temperature Volatility & 1.54 & $(0.11)$ & 0.94 & 1.72 & 593 \\
Access to Sea & 0.44 & $(0.49)$ & 0.00 & 1.00 & 593 \\
Coast Length & 3.44 & $(12.25)$ & 0.00 & 82.23 & 593 \\
Potential Pre-industrial Immobility & 74.60 & $(5.84)$ & 46.34 & 104.27 & 593 \\
Population & 20350.07 & $(107960.18)$ & 1224.00 & $2.51 \mathrm{e}+06$ & 593 \\
\hline \hline
\end{tabular}


Table A.2: Summary Statistics on Base Sample Department Level Analysis

\begin{tabular}{|c|c|c|c|c|c|}
\hline & Mean & Std & Min & Max & $\mathrm{N}$ \\
\hline Life Expectancy (1806-10) & 38.55 & $(7.07)$ & 22.10 & 52.30 & 86 \\
\hline Life Expectancy (1811-15) & 39.12 & $(6.19)$ & 23.10 & 50.70 & 86 \\
\hline Life Expectancy (1821-25) & 40.17 & $(7.49)$ & 19.40 & 52.70 & 86 \\
\hline Life Expectancy (1831-35) & 37.43 & $(6.45)$ & 23.30 & 50.90 & 86 \\
\hline Life Expectancy (1841-45) & 41.32 & $(6.09)$ & 27.10 & 52.70 & 86 \\
\hline Life Expectancy (1851-55) & 38.79 & $(6.11)$ & 25.80 & 50.80 & 86 \\
\hline Life Expectancy (1861-65) & 40.16 & $(8.05)$ & 18.20 & 55.20 & 89 \\
\hline Life Expectancy (1871-75) & 38.08 & $(5.30)$ & 25.70 & 48.80 & 86 \\
\hline Life Expectancy (1881-85) & 42.85 & $(6.06)$ & 26.10 & 51.50 & 86 \\
\hline Life Expectancy (1891-95) & 44.80 & $(4.55)$ & 31.00 & 51.90 & 86 \\
\hline Life Expectancy (1901-05) & 48.13 & $(3.67)$ & 38.90 & 54.50 & 86 \\
\hline Average Life Expectancy (1800-1850) & 39.41 & $(6.44)$ & 24.77 & 50.42 & 86 \\
\hline Average Life Expectancy (1850-1905) & 42.36 & $(4.81)$ & 29.06 & 51.15 & 89 \\
\hline Life Expectancy (1952-56) & 68.13 & $(1.34)$ & 64.70 & 70.70 & 88 \\
\hline Life Expectancy (1982) & 74.83 & $(1.00)$ & 71.90 & 76.50 & 88 \\
\hline Life Expectancy (2013) & 81.66 & $(0.89)$ & 78.95 & 83.25 & 89 \\
\hline Illiterate Conscripts (share, 1874) & 0.16 & $(0.10)$ & 0.01 & 0.43 & 87 \\
\hline Literate Conscripts (share, Read Only, 1874) & 0.02 & $(0.02)$ & 0.00 & 0.07 & 87 \\
\hline Literate Conscripts (share, no HSG, 1874) & 0.82 & $(0.11)$ & 0.54 & 0.99 & 87 \\
\hline Literate Conscripts (share, HSG Only, 1874) & 0.01 & $(0.01)$ & 0.00 & 0.04 & 87 \\
\hline Literate Conscripts (share, 1874) & 0.82 & $(0.11)$ & 0.54 & 0.99 & 87 \\
\hline Children Enrolled in Primary Schools (share, 1876) & 0.75 & $(0.13)$ & 0.17 & 1.00 & 89 \\
\hline University & 0.18 & $(0.39)$ & 0.00 & 1.00 & 89 \\
\hline Population Density (1800) & 0.92 & $(1.99)$ & 0.19 & 17.74 & 89 \\
\hline Urbanization (1800) & 0.24 & $(0.03)$ & 0.18 & 0.36 & 89 \\
\hline Railroad Connection to Paris (1870) & 0.98 & $(0.15)$ & 0.00 & 1.00 & 89 \\
\hline Employment Share in Agriculture (1876) & 0.62 & $(0.15)$ & 0.02 & 0.89 & 87 \\
\hline Employment share in Industry (1876) & 0.26 & $(0.12)$ & 0.06 & 0.64 & 87 \\
\hline Employment share in Services (1876) & 0.12 & $(0.06)$ & 0.05 & 0.39 & 87 \\
\hline Railroad Connection to Paris (1850) & 0.02 & $(0.15)$ & 0.00 & 1.00 & 89 \\
\hline Non-French Speaking Adults (share, 1864) & 0.24 & $(0.31)$ & 0.04 & 0.95 & 88 \\
\hline Urbanization (1800) & 0.24 & $(0.03)$ & 0.18 & 0.36 & 89 \\
\hline Literate Conscripts (share, 1838) & 0.54 & $(0.21)$ & 0.07 & 0.97 & 86 \\
\hline Diabetes type $1 \&$ type 2 (Prevalence) & 2.69 & $(0.46)$ & 1.56 & 3.89 & 89 \\
\hline Diabetes type $1 \&$ type 2 (Incidence) & 0.25 & $(0.04)$ & 0.15 & 0.34 & 89 \\
\hline Diabetes (Mortality Rate, all) & 21.72 & $(6.02)$ & 10.19 & 40.67 & 88 \\
\hline Diabetes (Mortality Rate, female) & 22.43 & $(6.38)$ & 10.11 & 40.61 & 88 \\
\hline Diabetes (Mortality Rate, male) & 20.98 & $(5.86)$ & 10.28 & 40.70 & 88 \\
\hline Arterial ischemic events & 0.91 & $(0.18)$ & 0.22 & 1.00 & 89 \\
\hline Heart Disease & 1.07 & $(0.10)$ & 1.00 & 1.44 & 89 \\
\hline Severe arterial disease & 1.51 & $(0.53)$ & 1.00 & 3.44 & 89 \\
\hline Coronary artery disease & 0.12 & $(0.02)$ & 0.08 & 0.16 & 89 \\
\hline Alzheimer's disease \& other dementias & 0.12 & $(0.21)$ & 0.00 & 1.00 & 89 \\
\hline Arterial ischemic events & 0.09 & $(0.01)$ & 0.06 & 0.12 & 89 \\
\hline
\end{tabular}


Table A.2: Summary Statistics on Base Sample Department Level Analysis

(Cont.)

\begin{tabular}{|c|c|c|c|c|c|}
\hline & Mean & Std & Min & Max & $\mathrm{N}$ \\
\hline Heart Disease & 0.14 & $(0.02)$ & 0.09 & 0.19 & 89 \\
\hline Active chronic liver disease \& cirrhosis & 0.03 & $(0.01)$ & 0.02 & 0.05 & 89 \\
\hline Severe arterial disease & 0.14 & $(0.05)$ & 0.06 & 0.32 & 89 \\
\hline Coronary artery disease & 1.37 & $(0.28)$ & 1.00 & 2.00 & 89 \\
\hline Alzheimer's disease \& other dementias & 0.08 & $(0.01)$ & 0.06 & 0.14 & 89 \\
\hline Parkinson's disease & 0.02 & $(0.01)$ & 0.00 & 0.03 & 89 \\
\hline Ulcerative colitis \& Crohn's disease & 0.01 & $(0.01)$ & 0.00 & 0.02 & 89 \\
\hline Active tuberculosis, leprosy & 0.00 & $(0.00)$ & 0.00 & 0.02 & 84 \\
\hline Influenza (Mortality Rate, all) & 0.94 & $(0.47)$ & 0.29 & 3.33 & 88 \\
\hline Pneumonia (Mortality Rate, all) & 19.52 & $(4.20)$ & 12.42 & 33.36 & 88 \\
\hline Tuberculosis (Mortality Rate, all) & 1.37 & $(0.38)$ & 0.68 & 2.66 & 88 \\
\hline Infectious Diseases (Mortality Rate, all) & 18.12 & $(3.05)$ & 12.19 & 27.84 & 89 \\
\hline HIV (Mortality Rate, all) & 0.95 & $(0.62)$ & 0.11 & 3.70 & 89 \\
\hline Hepatitis (Mortality Rate, all) & 1.15 & $(0.46)$ & 0.33 & 2.89 & 88 \\
\hline Asthma (Mortality Rate, all) & 2.06 & $(0.55)$ & 1.03 & 4.12 & 88 \\
\hline Endocrinian Diseases (Mortality Rate, all) & 37.30 & $(9.55)$ & 20.60 & 76.71 & 88 \\
\hline Diabetes (Mortality Rate, all) & 21.72 & $(6.02)$ & 10.19 & 40.67 & 88 \\
\hline Circulatory Diseases (Mortality Rate, all) & 286.27 & $(63.85)$ & 148.73 & 494.39 & 88 \\
\hline Tumors (Mortality Rate, all) & 278.97 & $(41.75)$ & 188.54 & 407.54 & 89 \\
\hline Influenza (Mortality Rate, male) & 0.75 & $(0.39)$ & 0.26 & 2.22 & 88 \\
\hline Pneumonia (Mortality Rate, male) & 18.84 & $(4.34)$ & 10.68 & 32.12 & 88 \\
\hline Tuberculosis (Mortality Rate, male) & 1.48 & $(0.45)$ & 0.90 & 3.45 & 88 \\
\hline Infectious Diseases (Mortality Rate, male) & 18.67 & $(3.56)$ & 11.98 & 28.93 & 89 \\
\hline HIV (Mortality Rate, male) & 1.52 & $(1.01)$ & 0.22 & 6.00 & 89 \\
\hline Hepatitis (Mortality Rate, male) & 1.32 & $(0.55)$ & 0.39 & 3.15 & 88 \\
\hline Asthma (Mortality Rate, male) & 1.54 & $(0.44)$ & 0.91 & 3.19 & 88 \\
\hline Endocrinian Diseases (Mortality Rate, male) & 32.94 & $(8.65)$ & 17.87 & 69.20 & 88 \\
\hline Diabetes (Mortality Rate, male) & 20.98 & $(5.86)$ & 10.28 & 40.70 & 88 \\
\hline Circulatory Diseases (Mortality Rate, male) & 276.54 & $(64.19)$ & 141.40 & 476.83 & 88 \\
\hline Tumors (Mortality Rate, male) & 342.46 & $(54.70)$ & 222.28 & 508.12 & 89 \\
\hline Influenza (Mortality Rate, female) & 1.12 & $(0.61)$ & 0.33 & 4.46 & 88 \\
\hline Pneumonia (Mortality Rate, female) & 20.19 & $(4.24)$ & 13.18 & 34.56 & 88 \\
\hline Tuberculosis (Mortality Rate, female) & 1.27 & $(0.40)$ & 0.43 & 2.81 & 88 \\
\hline Infectious Diseases (Mortality Rate, female) & 17.61 & $(2.87)$ & 11.37 & 26.77 & 89 \\
\hline HIV (Mortality Rate, female) & 0.42 & $(0.31)$ & 0.00 & 1.64 & 89 \\
\hline Hepatitis (Mortality Rate, female) & 1.00 & $(0.45)$ & 0.00 & 2.63 & 88 \\
\hline Asthma (Mortality Rate, female) & 2.54 & $(0.76)$ & 1.11 & 5.82 & 88 \\
\hline Endocrinian Diseases (Mortality Rate, female) & 41.44 & $(10.62)$ & 23.22 & 83.84 & 88 \\
\hline Diabetes (Mortality Rate, female) & 22.43 & $(6.38)$ & 10.11 & 40.61 & 88 \\
\hline Circulatory Diseases (Mortality Rate, female) & 295.51 & $(64.04)$ & 155.76 & 511.08 & 88 \\
\hline Tumors (Mortality Rate, female) & 218.98 & $(30.45)$ & 156.24 & 312.06 & 89 \\
\hline Suicides (Mortality Rate, all) & 47.90 & $(9.67)$ & 13.73 & 72.97 & 88 \\
\hline Suicides (Mortality Rate, female) & 41.86 & $(8.67)$ & 7.96 & 66.47 & 88 \\
\hline Suicides (Mortality Rate, male) & 54.28 & $(11.17)$ & 19.62 & 79.85 & 88 \\
\hline
\end{tabular}


Table A.2: Summary Statistics on Base Sample Department Level Analysis (Cont.)

\begin{tabular}{|c|c|c|c|c|c|}
\hline & Mean & Std & Min & Max & $\mathrm{N}$ \\
\hline Accidents (Mortality Rate, all) & 19.97 & $(4.80)$ & 5.78 & 33.58 & 89 \\
\hline Accidents (Mortality Rate, female) & 9.87 & $(2.35)$ & 3.97 & 18.02 & 89 \\
\hline Accidents (Mortality Rate, male) & 30.65 & $(7.71)$ & 7.79 & 50.22 & 89 \\
\hline Falls (Mortality Rate, all) & 10.28 & $(2.11)$ & 5.35 & 16.72 & 88 \\
\hline Falls (Mortality Rate, female) & 10.19 & $(2.02)$ & 5.34 & 16.55 & 88 \\
\hline Falls (Mortality Rate, male) & 10.38 & $(2.39)$ & 5.16 & 16.89 & 88 \\
\hline Population with Postgraduate Degree (share, 2010) & 0.23 & $(0.05)$ & 0.15 & 0.44 & 89 \\
\hline Men with Postgraduate Degree (share, 2010) & 0.21 & $(0.05)$ & 0.13 & 0.43 & 89 \\
\hline Male Life Expectancy 1982 & 70.76 & $(1.32)$ & 67.30 & 73.20 & 88 \\
\hline Women with Postgraduate Degree (share, 2010) & 0.24 & $(0.05)$ & 0.17 & 0.45 & 89 \\
\hline Female Life Expectancy 1982 & 78.91 & $(0.76)$ & 76.40 & 80.20 & 88 \\
\hline Women with High School Degree (share, 2010) & 0.17 & $(0.02)$ & 0.14 & 0.24 & 89 \\
\hline Women without Degree (share, 2010) & 0.20 & $(0.03)$ & 0.13 & 0.27 & 89 \\
\hline GDP per capita $(1860)$ & 498.18 & $(144.20)$ & 273.00 & 1105.00 & 87 \\
\hline GDP per capita $(1872)$ & 655.24 & $(198.13)$ & 235.60 & 1197.00 & 85 \\
\hline GDP per capita (1901) & 862.91 & $(270.96)$ & 255.30 & 1816.40 & 85 \\
\hline GDP per capita $(2010)$ & 24.65 & $(5.56)$ & 18.36 & 63.22 & 89 \\
\hline GDP per capita $(2000-2010)$ & 23.11 & $(4.64)$ & 17.66 & 55.25 & 89 \\
\hline Years Since Neolithic Revolution & 6859.48 & $(348.35)$ & 6060.85 & 7667.63 & 89 \\
\hline Years Since Neolithic Revolution (IV) & 6733.32 & $(613.77)$ & 5626.26 & 7609.07 & 89 \\
\hline Latitude & 46.48 & $(2.14)$ & 42.15 & 50.49 & 89 \\
\hline Agricultural Suitability & 0.74 & $(0.16)$ & 0.28 & 0.98 & 89 \\
\hline Caloric Suitability (pre-1500CE) & 8629.33 & $(600.30)$ & 7155.60 & 9695.06 & 89 \\
\hline Elevation & 360.73 & $(347.11)$ & 35.28 & 1672.49 & 89 \\
\hline Ruggedness & 114.90 & $(126.00)$ & 14.57 & 585.35 & 89 \\
\hline Precipitation (Avg.) & 69.64 & $(13.03)$ & 50.52 & 116.78 & 89 \\
\hline Precipitation Volatility & 36.82 & $(8.29)$ & 24.97 & 62.74 & 89 \\
\hline Temperature (Avg.) & 10.66 & $(1.52)$ & 5.25 & 13.97 & 89 \\
\hline Temperature Volatility & 1.52 & $(0.11)$ & 1.17 & 1.73 & 89 \\
\hline Access to Sea & 0.39 & $(0.44)$ & 0.00 & 1.00 & 89 \\
\hline Coast Length & 34.18 & $(83.09)$ & 0.00 & 384.14 & 89 \\
\hline Potential Pre-industrial Immobility & 1412.51 & $(333.93)$ & 144.57 & 2517.36 & 89 \\
\hline Population Density (1700) & 0.73 & $(1.54)$ & 0.15 & 13.58 & 89 \\
\hline
\end{tabular}




\section{B Additional Results}

\section{B.1 Changes in the Contribution of Mortality from Infectious Disease to Life Expectancy}

Panel A in Figure B.1 depicts the evolution of the distribution of deaths from all diseases by age and gender in France during the last 150 years. ${ }^{25}$ These figures clearly show the large decrease in mortality at young ages associated with the second epidemiological transition. Importantly, the changes in mortality during the post-epidemiological transition era have been accompanied by a compositional change in the causes of mortality, especially from infectious and parasitic diseases to autoimmune related diseases, as documented in Panels B-C. Moreover, Figure B.2 shows that mortality from autoimmune related diseases has increased relative to infectious diseases for all age groups for both genders as time passed. ${ }^{26}$

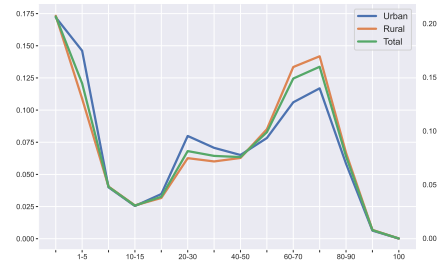

(a) Females (1856)

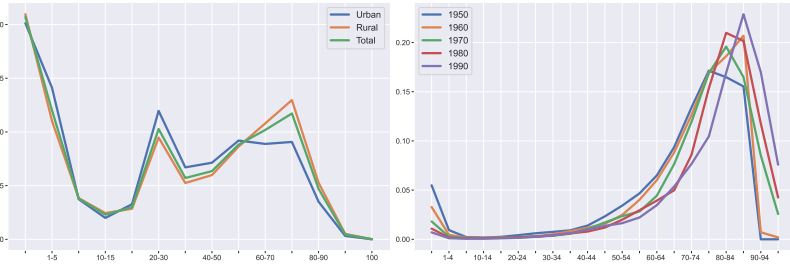

(b) Males (1856) (c) Females (1950-1999)

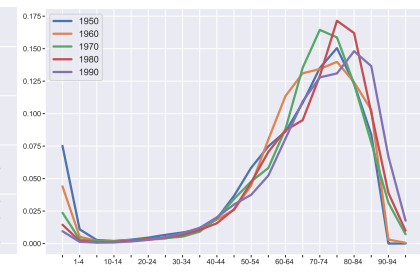

(d) Males (1950-1999)

Panel A: Distribution of Deaths from All Diseases by Age and Gender in France (1856, 1950-1999)

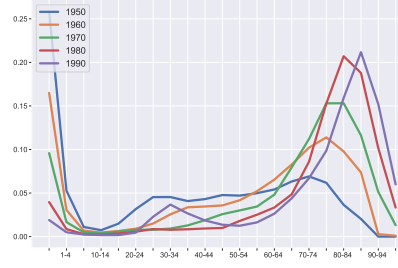

(e) Infectious - Females

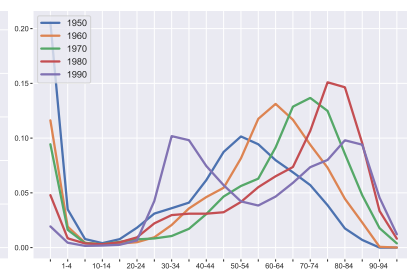

(f) Infectious - Males

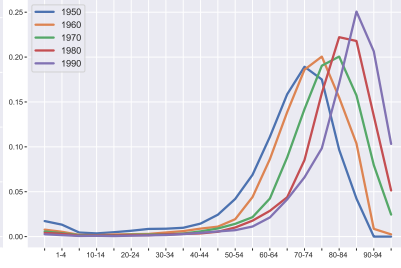

(g) Autoimmune - Females

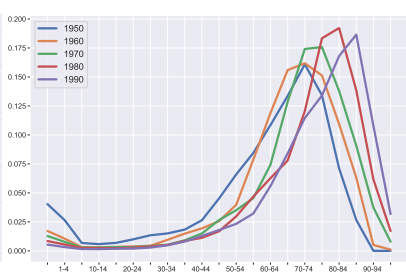

(h) Autoimmune - Males

Panel B: Distribution of Deaths from Infectious and Autoimmune Related Diseases by Age and Gender (1950-1999)

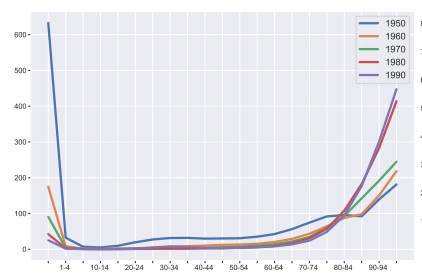

(i) Infectious - Females

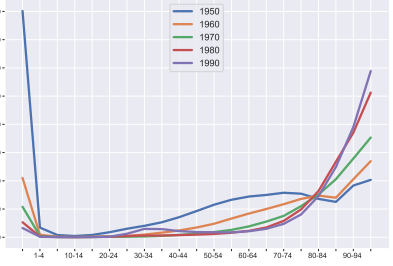

(j) Infectious - Males

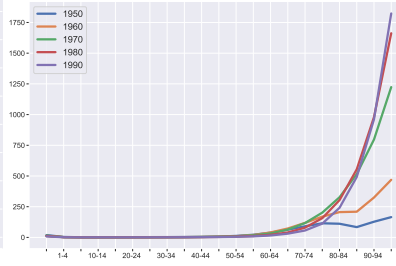

(k) Autoimmune - Females

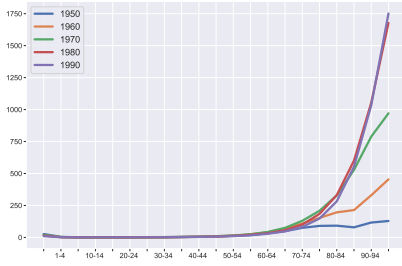

(1) Autoimmune - Males

Panel C: Death Rates from Infectious and Autoimmune Diseases by Age and Gender in France (1950-1999)

Figure B.1: Evolution of Deaths and Death Rates in France

\footnotetext{
${ }^{25}$ See Figures in Appendix E for the evolution of all major disease categories.

${ }^{26}$ The observable reversal in this tendency for the post-1980 period for individuals in the ages $20-44$ seems to be mainly driven by the emergence of HIV.
} 


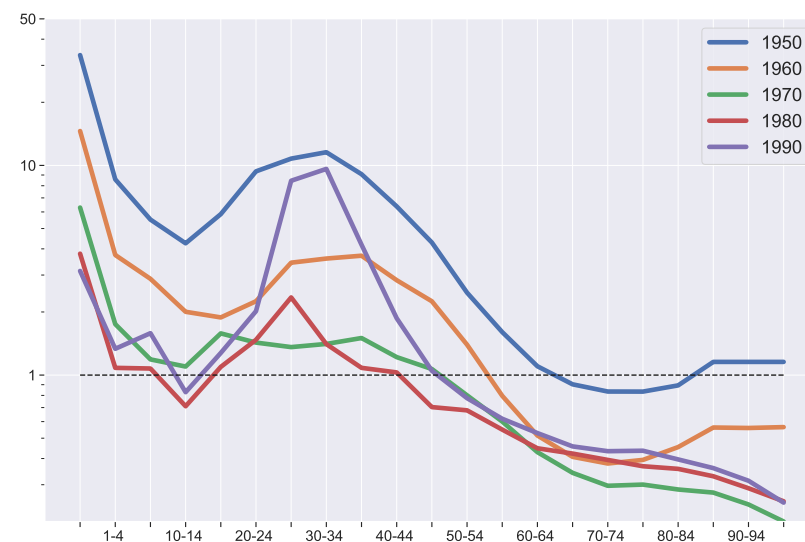

(a) Females

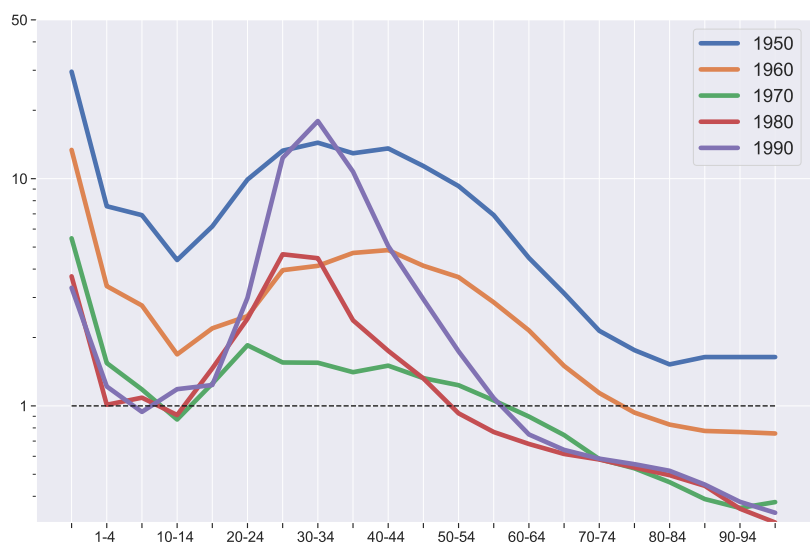

(b) Males

Figure B.2: Evolution of Mortality Ratio of Infectious vs. Autoimmune Diseases by Age and Gender in France (1950-1999) 


\section{B.2 Département-Level Results}

Table B.1: Neolithic Revolution and Life Expectancy (1871-1875, Pinhasi Subsample)

\begin{tabular}{|c|c|c|c|c|c|c|}
\hline & \multicolumn{6}{|c|}{ Log Life Expectancy (1871-1875) } \\
\hline & \multicolumn{3}{|c|}{ OLS } & \multicolumn{3}{|c|}{ IV } \\
\hline & (1) & $(2)$ & $(3)$ & $(4)$ & $(5)$ & (6) \\
\hline Years Since Neolithic Revolution & $\begin{array}{c}0.20 \\
(0.15)\end{array}$ & $\begin{array}{l}0.21^{*} \\
(0.11)\end{array}$ & $\begin{array}{l}0.22^{*} \\
(0.12)\end{array}$ & $\begin{array}{c}0.27^{* *} \\
(0.12)\end{array}$ & $\begin{array}{c}0.61^{* *} \\
(0.31)\end{array}$ & $\begin{array}{c}0.54^{* *} \\
(0.25)\end{array}$ \\
\hline Geographical Controls & Abs. Lat. & All & All & Abs. Lat. & All & All \\
\hline Population Density (1700) & No & No & Yes & No & No & Yes \\
\hline First-stage F-statistic & & & & 183.55 & 8.14 & 15.23 \\
\hline Adjusted- $R^{2}$ & 0.12 & 0.55 & 0.57 & 0.57 & 0.41 & 0.51 \\
\hline Observations & 42 & 42 & 42 & 42 & 42 & 42 \\
\hline
\end{tabular}

Notes: Standardized coefficients from Ordinary Least Squares (OLS) and Instrumental Variables (IV) regressions. Heteroskedasticity robust standard error estimates are reported in parentheses; *** denotes statistical significance at the $1 \%$ level, ${ }^{* *}$ at the $5 \%$ level, and $*$ at the $10 \%$ level, all for two-sided hypothesis tests. 
Table B.2: Neolithic Revolution, Human Capital and Life Expectancy (1901-1905)

\begin{tabular}{|c|c|c|c|c|c|c|c|}
\hline & \multicolumn{7}{|c|}{ Log Life Expectancy (1901-1905) } \\
\hline & $(1)$ & $(2)$ & (3) & (4) & (5) & (6) & (7) \\
\hline Years Since Neolithic Revolution & $\begin{array}{l}0.32^{* * *} \\
(0.10)\end{array}$ & $\begin{array}{l}0.29^{* * *} \\
(0.10)\end{array}$ & $\begin{array}{l}0.32^{* * *} \\
(0.10)\end{array}$ & $\begin{array}{l}0.32^{* * *} \\
(0.10)\end{array}$ & $\begin{array}{l}0.32^{\text {*** }} \\
(0.10)\end{array}$ & $\begin{array}{l}0.31^{* * *} \\
(0.10)\end{array}$ & $\begin{array}{l}0.30^{* * *} \\
(0.10)\end{array}$ \\
\hline Illiterate Conscripts (share, 1874) & $\begin{array}{l}-0.08 \\
(0.09)\end{array}$ & & & & & & \\
\hline Literate Conscripts (share, Read Only, 1874) & & $\begin{array}{l}-0.19^{* *} \\
(0.08)\end{array}$ & & & & & \\
\hline Literate Conscripts (share, no HSG, 1874) & & & $\begin{array}{l}0.10 \\
(0.09)\end{array}$ & & & & \\
\hline Literate Conscripts (share, HSG Only, 1874) & & & & $\begin{array}{l}0.08 \\
(0.09)\end{array}$ & & & \\
\hline Literate Conscripts (share, 1874) & & & & & $\begin{array}{l}0.11 \\
(0.09)\end{array}$ & & \\
\hline Children Enrolled in Primary Schools (share, 1876) & & & & & & $\begin{array}{l}0.10 \\
(0.10)\end{array}$ & \\
\hline University & & & & & & & $\begin{array}{l}-0.04 \\
(0.06)\end{array}$ \\
\hline Main Geographical Controls & Yes & Yes & Yes & Yes & Yes & Yes & Yes \\
\hline Adjusted- $R^{2}$ & 0.58 & 0.60 & 0.58 & 0.58 & 0.58 & 0.58 & 0.58 \\
\hline Observations & 86 & 86 & 86 & 86 & 86 & 86 & 86 \\
\hline
\end{tabular}

Notes: Standardized coefficients from Ordinary Least Squares (OLS) regression. Heteroskedasticity robust standard error estimates are reported in parentheses; ${ }^{* * *}$ denotes statistical significance at the $1 \%$ level, ** at the $5 \%$ level, and $*$ at the $10 \%$ level, all for two-sided hypothesis tests. 
Table B.3: Neolithic Revolution, Development and Life Expectancy (1901-1905)

\begin{tabular}{|c|c|c|c|c|c|c|c|}
\hline & \multicolumn{7}{|c|}{ Log Life Expectancy (1901-1905) } \\
\hline & \multicolumn{4}{|c|}{ Development } & \multicolumn{3}{|c|}{ Composition } \\
\hline & (1) & $(2)$ & $(3)$ & $(4)$ & $(5)$ & (6) & $(7)$ \\
\hline Years Since Neolithic Revolution & $\begin{array}{l}0.29 * * * \\
(0.10)\end{array}$ & $\begin{array}{l}0.30 * * * \\
(0.10)\end{array}$ & $\begin{array}{l}0.30 * * * \\
(0.10)\end{array}$ & $\begin{array}{l}0.32^{* * *} \\
(0.10)\end{array}$ & $\begin{array}{l}0.33^{* * *} \\
(0.10)\end{array}$ & $\begin{array}{l}0.33^{* * *} \\
(0.10)\end{array}$ & $\begin{array}{l}0.27^{* * *} \\
(0.10)\end{array}$ \\
\hline Population Density (1800) & $\begin{array}{l}-0.11^{*} \\
(0.06)\end{array}$ & & & & & & \\
\hline Urbanization (1800) & & $\begin{array}{l}-0.17^{* *} \\
(0.08)\end{array}$ & & & & & \\
\hline GDP per capita $(1872)$ & & & $\begin{array}{l}0.07 \\
(0.09)\end{array}$ & & & & \\
\hline Railroad Connection to Paris (1870) & & & & $\begin{array}{l}0.05 \\
(0.04)\end{array}$ & & & \\
\hline Employment Share in Agriculture (1876) & & & & & $\begin{array}{l}0.27 * * * \\
(0.09)\end{array}$ & & \\
\hline Employment share in Industry (1876) & & & & & & $\begin{array}{c}-0.18^{*} \\
(0.09)\end{array}$ & \\
\hline Employment share in Services (1876) & & & & & & & $\begin{array}{l}-0.31^{* * *} \\
(0.09)\end{array}$ \\
\hline Main Geographical Controls & Yes & Yes & Yes & Yes & Yes & Yes & Yes \\
\hline Adjusted- $R^{2}$ & 0.59 & 0.60 & 0.58 & 0.58 & 0.61 & 0.59 & 0.63 \\
\hline Observations & 85 & 85 & 85 & 85 & 85 & 85 & 85 \\
\hline
\end{tabular}

Notes: Standardized coefficients from Ordinary Least Squares (OLS) regression. Heteroskedasticity robust standard error estimates are reported in parentheses; *** denotes statistical significance at the $1 \%$ level, ** at the $5 \%$ level, and * at the $10 \%$ level, all for two-sided hypothesis tests. 
Table B.4: Neolithic Revolution and Life Expectancy (1901-1906)

\begin{tabular}{|c|c|c|c|c|c|c|c|c|c|}
\hline & \multicolumn{9}{|c|}{ Log Life Expectancy (1901-1906) } \\
\hline & \multicolumn{3}{|c|}{ OLS } & \multicolumn{3}{|c|}{ Reduced Form } & \multicolumn{3}{|c|}{ IV } \\
\hline & $(1)$ & $(2)$ & $(3)$ & $(4)$ & $(5)$ & $(6)$ & $(7)$ & (8) & $(9)$ \\
\hline Years Since Neolithic Revolution & $\begin{array}{l}0.42^{* * *} \\
(0.11)\end{array}$ & $\begin{array}{l}0.30 * * * \\
(0.10)\end{array}$ & $\begin{array}{l}0.29^{* * *} \\
(0.10)\end{array}$ & $\begin{array}{l}0.31^{* *} \\
(0.13)\end{array}$ & $\begin{array}{l}0.26^{* *} \\
(0.12)\end{array}$ & $\begin{array}{l}0.27^{* *} \\
(0.12)\end{array}$ & $\begin{array}{l}0.59^{* *} \\
(0.24)\end{array}$ & $\begin{array}{l}0.32^{* *} \\
(0.14)\end{array}$ & $\begin{array}{l}0.33^{* *} \\
(0.13)\end{array}$ \\
\hline Latitude & $\begin{array}{l}0.27^{* *} \\
(0.11)\end{array}$ & $\begin{array}{l}0.10 \\
(0.36)\end{array}$ & $\begin{array}{l}0.17 \\
(0.36)\end{array}$ & $\begin{array}{l}0.21^{*} \\
(0.11)\end{array}$ & $\begin{array}{l}-0.18 \\
(0.39)\end{array}$ & $\begin{array}{l}-0.07 \\
(0.38)\end{array}$ & $\begin{array}{l}0.38^{* *} \\
(0.17)\end{array}$ & $\begin{array}{l}0.11 \\
(0.33)\end{array}$ & $\begin{array}{l}0.20 \\
(0.32)\end{array}$ \\
\hline Agricultural Suitability & & $\begin{array}{l}0.08 \\
(0.13)\end{array}$ & $\begin{array}{l}0.06 \\
(0.13)\end{array}$ & & $\begin{array}{l}-0.01 \\
(0.15)\end{array}$ & $\begin{array}{l}-0.04 \\
(0.15)\end{array}$ & & $\begin{array}{l}0.09 \\
(0.12)\end{array}$ & $\begin{array}{l}0.06 \\
(0.12)\end{array}$ \\
\hline Caloric Suitability (pre-1500CE) & & $\begin{array}{l}-0.24^{* *} \\
(0.12)\end{array}$ & $\begin{array}{l}-0.23^{*} \\
(0.12)\end{array}$ & & $\begin{array}{l}-0.28^{* *} \\
(0.12)\end{array}$ & $\begin{array}{l}-0.27^{* *} \\
(0.12)\end{array}$ & & $\begin{array}{l}-0.24^{* *} \\
(0.11)\end{array}$ & $\begin{array}{c}-0.23^{* *} \\
(0.11)\end{array}$ \\
\hline Elevation & & $\begin{array}{l}0.51 \\
(0.54)\end{array}$ & $\begin{array}{l}0.58 \\
(0.53)\end{array}$ & & $\begin{array}{l}0.04 \\
(0.61)\end{array}$ & $\begin{array}{l}0.12 \\
(0.61)\end{array}$ & & $\begin{array}{l}0.51 \\
(0.50)\end{array}$ & $\begin{array}{l}0.58 \\
(0.49)\end{array}$ \\
\hline Ruggedness & & $\begin{array}{l}-0.46^{*} \\
(0.23)\end{array}$ & $\begin{array}{c}-0.41^{*} \\
(0.24)\end{array}$ & & $\begin{array}{l}-0.51^{* *} \\
(0.23)\end{array}$ & $\begin{array}{l}-0.44^{*} \\
(0.24)\end{array}$ & & $\begin{array}{l}-0.46^{* *} \\
(0.21)\end{array}$ & $\begin{array}{c}-0.41^{*} \\
(0.22)\end{array}$ \\
\hline Precipitation (Avg.) & & $\begin{array}{l}-0.41 \\
(0.29)\end{array}$ & $\begin{array}{l}-0.36 \\
(0.28)\end{array}$ & & $\begin{array}{l}-0.74^{* *} \\
(0.35)\end{array}$ & $\begin{array}{l}-0.69^{* *} \\
(0.34)\end{array}$ & & $\begin{array}{l}-0.41 \\
(0.26)\end{array}$ & $\begin{array}{l}-0.37 \\
(0.26)\end{array}$ \\
\hline Precipitation Volatility & & $\begin{array}{l}-0.04 \\
(0.35)\end{array}$ & $\begin{array}{l}-0.10 \\
(0.34)\end{array}$ & & $\begin{array}{l}0.20 \\
(0.42)\end{array}$ & $\begin{array}{l}0.14 \\
(0.40)\end{array}$ & & $\begin{array}{l}-0.03 \\
(0.32)\end{array}$ & $\begin{array}{l}-0.09 \\
(0.31)\end{array}$ \\
\hline Temperature (Avg.) & & $\begin{array}{l}0.18 \\
(0.46)\end{array}$ & $\begin{array}{l}0.31 \\
(0.46)\end{array}$ & & $\begin{array}{l}-0.32 \\
(0.55)\end{array}$ & $\begin{array}{l}-0.16 \\
(0.54)\end{array}$ & & $\begin{array}{l}0.18 \\
(0.42)\end{array}$ & $\begin{array}{l}0.30 \\
(0.41)\end{array}$ \\
\hline Temperature Volatility & & $\begin{array}{l}0.15 \\
(0.22)\end{array}$ & $\begin{array}{l}0.17 \\
(0.23)\end{array}$ & & $\begin{array}{l}0.07 \\
(0.23)\end{array}$ & $\begin{array}{l}0.09 \\
(0.23)\end{array}$ & & $\begin{array}{l}0.15 \\
(0.20)\end{array}$ & $\begin{array}{l}0.17 \\
(0.21)\end{array}$ \\
\hline Access to Sea & & $\begin{array}{l}-0.17 \\
(0.14)\end{array}$ & $\begin{array}{l}-0.17 \\
(0.14)\end{array}$ & & $\begin{array}{l}-0.20 \\
(0.15)\end{array}$ & $\begin{array}{l}-0.20 \\
(0.15)\end{array}$ & & $\begin{array}{l}-0.17 \\
(0.13)\end{array}$ & $\begin{array}{l}-0.17 \\
(0.13)\end{array}$ \\
\hline Coast Length & & $\begin{array}{l}-0.35^{* *} \\
(0.17)\end{array}$ & $\begin{array}{l}-0.35^{* *} \\
(0.17)\end{array}$ & & $\begin{array}{l}-0.34^{* *} \\
(0.16)\end{array}$ & $\begin{array}{l}-0.34^{* *} \\
(0.16)\end{array}$ & & $\begin{array}{l}-0.35^{* *} \\
(0.16)\end{array}$ & $\begin{array}{l}-0.35^{* *} \\
(0.16)\end{array}$ \\
\hline Potential Pre-industrial Immobility & & $\begin{array}{l}0.35^{* * *} \\
(0.08)\end{array}$ & $\begin{array}{l}0.31^{* * *} \\
(0.09)\end{array}$ & & $\begin{array}{l}0.34^{* * *} \\
(0.09)\end{array}$ & $\begin{array}{l}0.29 * * * \\
(0.09)\end{array}$ & & $\begin{array}{l}0.35^{* * *} \\
(0.07)\end{array}$ & $\begin{array}{l}0.31^{* * *} \\
(0.08)\end{array}$ \\
\hline Population Density (1700) & & & $\begin{array}{l}-0.10 \\
(0.07)\end{array}$ & & & $\begin{array}{c}-0.13^{*} \\
(0.07)\end{array}$ & & & $\begin{array}{l}-0.10 \\
(0.06)\end{array}$ \\
\hline First-stage F-statistic & & & & & & & 58.72 & 55.77 & 55.12 \\
\hline Adjusted- $R^{2}$ & 0.09 & 0.58 & 0.58 & 0.03 & 0.55 & 0.56 & 0.07 & 0.58 & 0.58 \\
\hline Observations & 86 & 86 & 86 & 86 & 86 & 86 & 86 & 86 & 86 \\
\hline
\end{tabular}

Notes: Standardized coefficients from Ordinary Least Squares (OLS) and Instrumental Variables (IV) regressions. Heteroskedasticity robust standard error estimates are reported in parentheses; *** denotes statistical significance at the $1 \%$ level, ${ }^{* *}$ at the $5 \%$ level, and * at the $10 \%$ level, all for two-sided hypothesis tests. 
Table B.5: Neolithic Revolution, Development and Life Expectancy (1901-1905)

\begin{tabular}{|c|c|c|c|c|c|c|c|}
\hline & \multicolumn{7}{|c|}{ Log Life Expectancy (1901-1905) } \\
\hline & \multicolumn{4}{|c|}{ Development } & \multicolumn{3}{|c|}{ Composition } \\
\hline & $(1)$ & $(2)$ & $(3)$ & $(4)$ & $(5)$ & $(6)$ & $(7)$ \\
\hline Years Since Neolithic Revolution & $\begin{array}{l}0.35^{* *} \\
(0.14)\end{array}$ & $\begin{array}{l}0.34^{* * *} \\
(0.13)\end{array}$ & $\begin{array}{l}0.34^{* *} \\
(0.14)\end{array}$ & $\begin{array}{l}0.36^{* *} \\
(0.14)\end{array}$ & $\begin{array}{l}0.46^{* * *} \\
(0.13)\end{array}$ & $\begin{array}{l}0.43^{* * *} \\
(0.13)\end{array}$ & $\begin{array}{l}0.39 * * * \\
(0.13)\end{array}$ \\
\hline Population Density (1800) & $\begin{array}{l}-0.10^{*} \\
(0.05)\end{array}$ & & & & & & \\
\hline Urbanization (1800) & & $\begin{array}{l}-0.17^{* *} \\
(0.08)\end{array}$ & & & & & \\
\hline GDP per capita (1872) & & & $\begin{array}{l}0.07 \\
(0.09)\end{array}$ & & & & \\
\hline Railroad Connection to Paris (1870) & & & & $\begin{array}{l}0.06 \\
(0.04)\end{array}$ & & & \\
\hline Employment Share in Agriculture (1876) & & & & & $\begin{array}{l}0.29 * * * \\
(0.08)\end{array}$ & & \\
\hline Employment share in Industry (1876) & & & & & & $\begin{array}{l}-0.20 * * \\
(0.08)\end{array}$ & \\
\hline Employment share in Services (1876) & & & & & & & $\begin{array}{l}-0.30^{* * *} \\
(0.09)\end{array}$ \\
\hline Main Geographical Controls & Yes & Yes & Yes & Yes & Yes & Yes & Yes \\
\hline First-stage F-statistic & 54.75 & 54.76 & 56.02 & 57.80 & 45.10 & 44.99 & 60.81 \\
\hline Adjusted- $R^{2}$ & 0.58 & 0.60 & 0.58 & 0.58 & 0.60 & 0.59 & 0.62 \\
\hline Observations & 85 & 85 & 85 & 85 & 85 & 85 & 85 \\
\hline
\end{tabular}

Notes: Standardized coefficients from Instrumental Variables (IV) regression. Heteroskedasticity robust standard error estimates are reported in parentheses; *** denotes statistical significance at the $1 \%$ level, ** at the $5 \%$ level, and * at the $10 \%$ level, all for two-sided hypothesis tests. 
Table B.6: Neolithic Revolution, Human Capital and Life Expectancy (1901-1905)

\begin{tabular}{|c|c|c|c|c|c|c|c|}
\hline & \multicolumn{7}{|c|}{ Log Life Expectancy (1901-1905) } \\
\hline & $(1)$ & $(2)$ & $(3)$ & $(4)$ & $(5)$ & $(6)$ & $(7)$ \\
\hline Years Since Neolithic Revolution & $\begin{array}{l}0.31^{* *} \\
(0.13)\end{array}$ & $\begin{array}{l}0.29 * * \\
(0.14)\end{array}$ & $\begin{array}{l}0.31^{* *} \\
(0.13)\end{array}$ & $\begin{array}{l}0.31^{* *} \\
(0.13)\end{array}$ & $\begin{array}{l}0.30^{* *} \\
(0.13)\end{array}$ & $\begin{array}{l}0.29 * * \\
(0.12)\end{array}$ & $\begin{array}{l}0.33^{* *} \\
(0.13)\end{array}$ \\
\hline Illiterate Conscripts (share, 1874) & $\begin{array}{l}-0.07 \\
(0.08)\end{array}$ & & & & & & \\
\hline Literate Conscripts (share, Read Only, 1874) & & $\begin{array}{l}-0.19^{* *} \\
(0.07)\end{array}$ & & & & & \\
\hline Literate Conscripts (share, no HSG, 1874) & & & $\begin{array}{l}0.10 \\
(0.09)\end{array}$ & & & & \\
\hline Literate Conscripts (share, HSG Only, 1874) & & & & $\begin{array}{l}0.07 \\
(0.09)\end{array}$ & & & \\
\hline Literate Conscripts (share, 1874) & & & & & $\begin{array}{l}0.10 \\
(0.09)\end{array}$ & & \\
\hline Children Enrolled in Primary Schools (share, 1876) & & & & & & $\begin{array}{l}0.10 \\
(0.09)\end{array}$ & \\
\hline University & & & & & & & $\begin{array}{l}-0.04 \\
(0.06)\end{array}$ \\
\hline Main Geographical Controls & Yes & Yes & Yes & Yes & Yes & Yes & Yes \\
\hline First-stage F-statistic & 69.14 & 55.10 & 69.29 & 63.09 & 70.56 & 67.91 & 51.61 \\
\hline Adjusted- $R^{2}$ & 0.58 & 0.60 & 0.58 & 0.58 & 0.58 & 0.58 & 0.58 \\
\hline Observations & 86 & 86 & 86 & 86 & 86 & 86 & 86 \\
\hline
\end{tabular}

Notes: Standardized coefficients from Instrumental Variables (IV) regression. Heteroskedasticity robust standard error estimates are reported in parentheses; $* * *$ denotes statistical significance at the $1 \%$ level, ** at the $5 \%$ level, and * at the $10 \%$ level, all for two-sided hypothesis tests. 


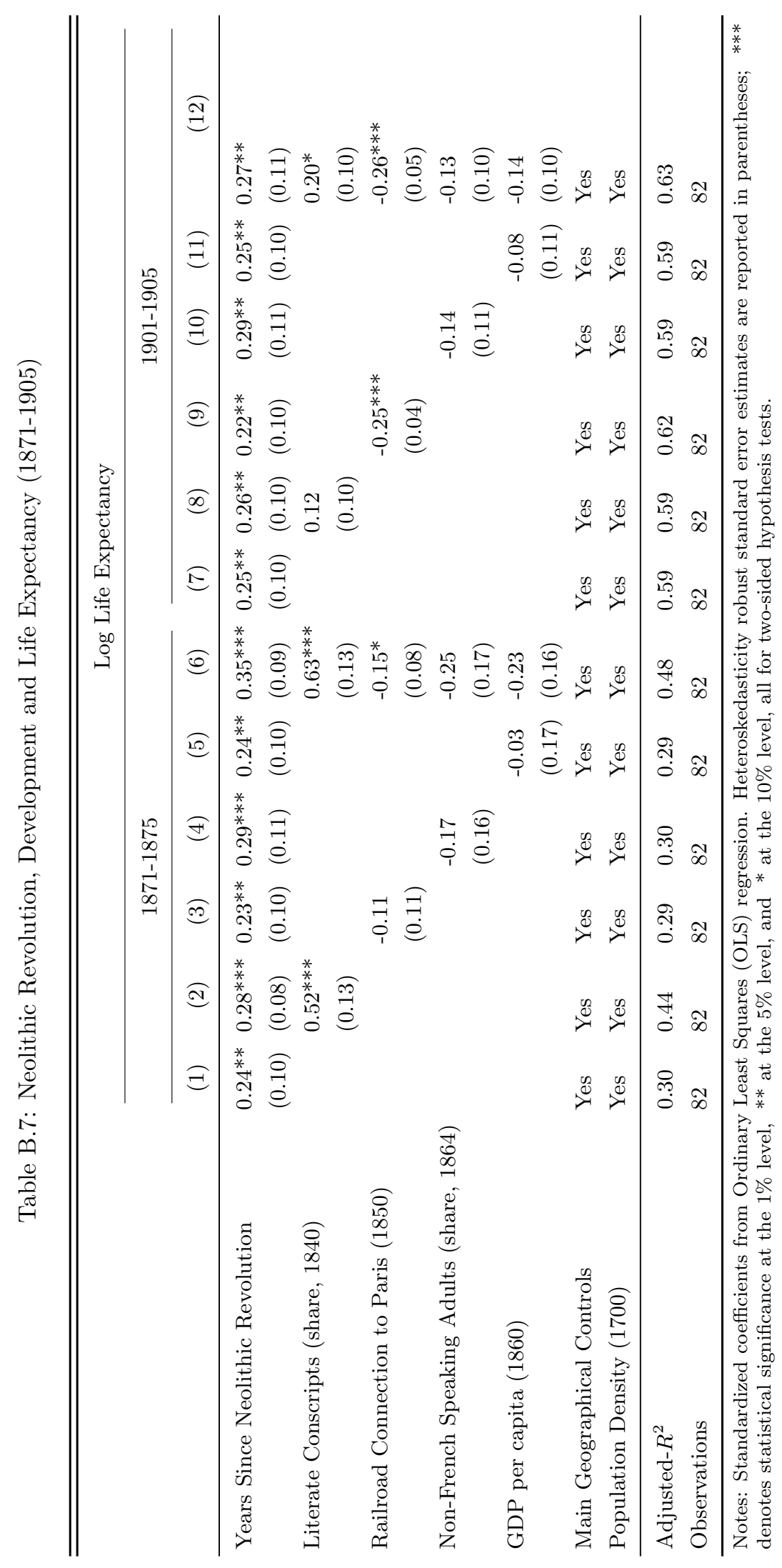




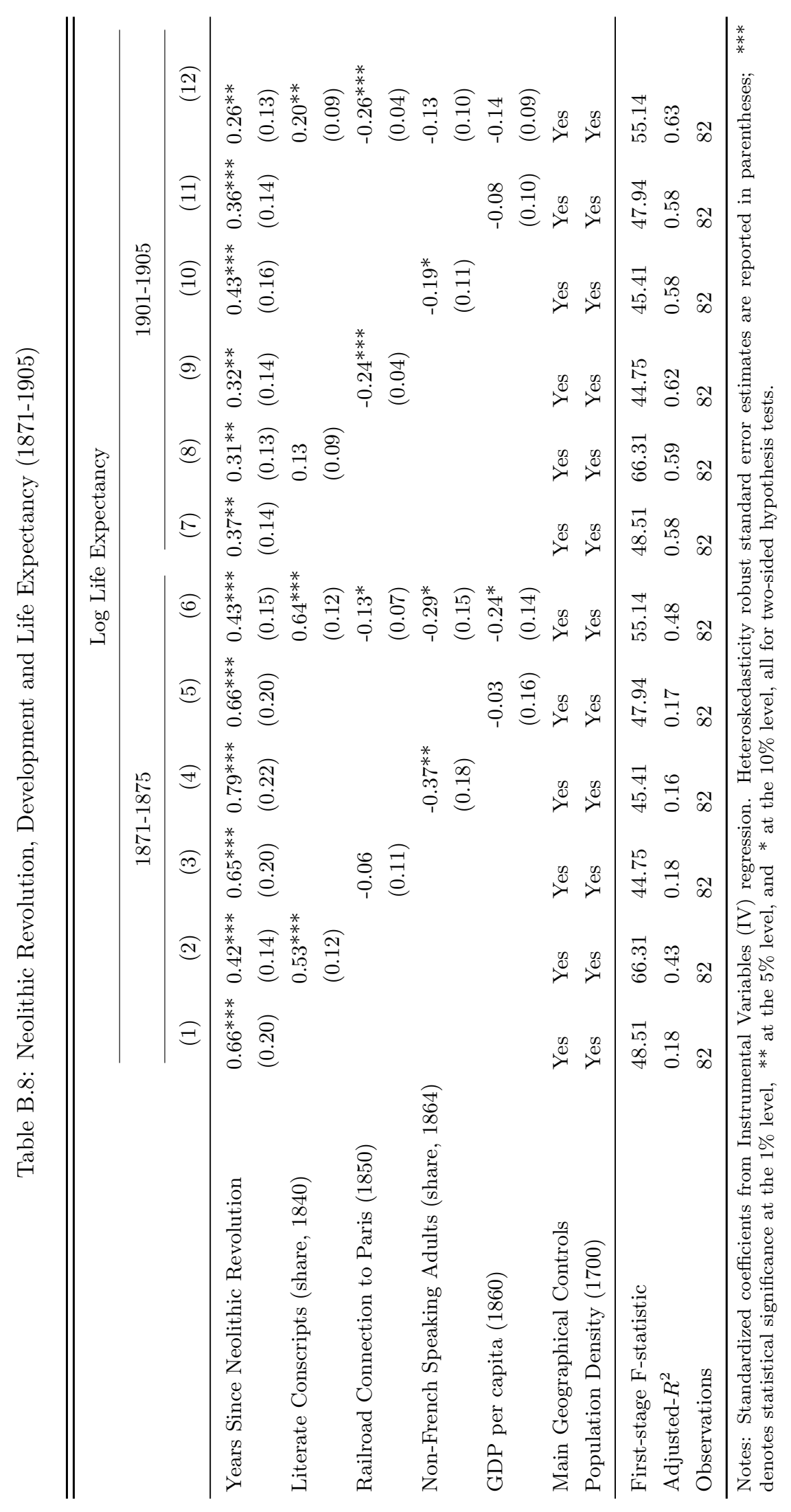


Table B.9: Neolithic Revolution and Département-Level Mortality (1900)

\begin{tabular}{|c|c|c|c|c|c|}
\hline & \multicolumn{5}{|c|}{ Mortality Rate across Départements (1900) } \\
\hline & All Diseases & $\begin{array}{c}\text { Infectious } \\
\text { (Air) }\end{array}$ & $\begin{array}{c}\text { Infectious } \\
\text { (Water) }\end{array}$ & Suicides & $\begin{array}{l}\text { Violent } \\
\text { Deaths }\end{array}$ \\
\hline & $(1)$ & $(2)$ & $(3)$ & $(4)$ & $(5)$ \\
\hline Years Since Neolithic Revolution & $\begin{array}{c}-0.71^{* * *} \\
(0.19)\end{array}$ & $\begin{array}{c}-0.46^{* * *} \\
(0.16)\end{array}$ & $\begin{array}{c}0.24 \\
(0.24)\end{array}$ & $\begin{array}{l}-0.29 \\
(0.22)\end{array}$ & $\begin{array}{l}-0.27 \\
(0.22)\end{array}$ \\
\hline Main Geographical Controls & Yes & Yes & Yes & Yes & Yes \\
\hline Population Density (1700) & Yes & Yes & Yes & Yes & Yes \\
\hline Distance to Fresnes & Yes & Yes & Yes & Yes & Yes \\
\hline First-stage F-statistic & 33.90 & 33.90 & 33.90 & 33.90 & 33.90 \\
\hline Adjusted- $R^{2}$ & 0.05 & 0.22 & 0.12 & 0.06 & 0.24 \\
\hline Observations & 86 & 86 & 86 & 86 & 86 \\
\hline
\end{tabular}

Notes: Standardized coefficients from Instrumental Variables (IV) regression. Heteroskedasticity robust standard error estimates are reported in parentheses; *** denotes statistical significance at the $1 \%$ level, ** at the $5 \%$ level, and * at the $10 \%$ level, all for two-sided hypothesis tests.

Table B.10: Neolithic Revolution and Risk of Tuberculosis (2000-2013)

\begin{tabular}{|c|c|c|c|c|c|c|c|c|c|c|}
\hline & \multicolumn{10}{|c|}{ Tuberculosis } \\
\hline & \multicolumn{4}{|c|}{ Morbidity } & \multicolumn{6}{|c|}{ Death Rates per 100,000} \\
\hline & \multicolumn{2}{|c|}{ Prevalence } & \multicolumn{2}{|c|}{ Incidence } & \multicolumn{2}{|c|}{ Total } & \multicolumn{2}{|c|}{ Female } & \multicolumn{2}{|c|}{ Male } \\
\hline & (1) & $(2)$ & $(3)$ & $(4)$ & $(5)$ & (6) & $(7)$ & (8) & (9) & $(10)$ \\
\hline Years Since Neolithic Revolution & $\begin{array}{l}-0.22 \\
(0.14)\end{array}$ & $\begin{array}{l}-0.22 \\
(0.15)\end{array}$ & $\begin{array}{c}0.06 \\
(0.17)\end{array}$ & $\begin{array}{c}0.10 \\
(0.17)\end{array}$ & $\begin{array}{c}-0.33^{* *} \\
(0.13)\end{array}$ & $\begin{array}{c}-0.46^{* * *} \\
(0.13)\end{array}$ & $\begin{array}{c}-0.50^{* * *} \\
(0.13)\end{array}$ & $\begin{array}{c}-0.62^{* * *} \\
(0.14)\end{array}$ & $\begin{array}{l}-0.11 \\
(0.15)\end{array}$ & $\begin{array}{l}-0.23 \\
(0.14)\end{array}$ \\
\hline GDP per capita & & $\begin{array}{l}-0.02 \\
(0.15)\end{array}$ & & $\begin{array}{l}0.17^{*} \\
(0.09)\end{array}$ & & $\begin{array}{c}-0.49 * * * \\
(0.11)\end{array}$ & & $\begin{array}{c}-0.44^{* * *} \\
(0.12)\end{array}$ & & $\begin{array}{c}-0.45^{* * *} \\
(0.11)\end{array}$ \\
\hline Main Geographical Controls & Yes & Yes & Yes & Yes & Yes & Yes & Yes & Yes & Yes & Yes \\
\hline Population Density (1700) & Yes & Yes & Yes & Yes & Yes & Yes & Yes & Yes & Yes & Yes \\
\hline First-stage F-statistic & 55.24 & 50.20 & 53.34 & 48.30 & 54.54 & 49.97 & 54.54 & 49.97 & 54.54 & 49.97 \\
\hline Adjusted- $R^{2}$ & 0.59 & 0.58 & 0.47 & 0.47 & 0.21 & 0.27 & 0.10 & 0.11 & 0.24 & 0.30 \\
\hline Observations & 87 & 87 & 83 & 83 & 88 & 88 & 88 & 88 & 88 & 88 \\
\hline
\end{tabular}

Notes: Standardized coefficients from Instrumental Variables (IV) regression. Heteroskedasticity robust standard error estimates are reported in parentheses; *** denotes statistical significance at the $1 \%$ level, ** at the $5 \%$ level, and * at the $10 \%$ level, all for two-sided hypothesis tests. 
Table B.11: Placebo - Neolithic Revolution and Suicides (2000-2013)

\begin{tabular}{|c|c|c|c|c|c|c|}
\hline & \multicolumn{6}{|c|}{ Suicide Death Rates per 100,000} \\
\hline & \multicolumn{3}{|c|}{ OLS } & \multicolumn{3}{|c|}{ IV } \\
\hline & All & Female & Male & All & Female & Male \\
\hline & (1) & $(2)$ & $(3)$ & $(4)$ & (5) & (6) \\
\hline \multirow[t]{2}{*}{ Years Since Neolithic Revolution } & 0.07 & 0.12 & 0.03 & -0.07 & -0.04 & -0.09 \\
\hline & $(0.10)$ & $(0.12)$ & $(0.09)$ & $(0.15)$ & $(0.16)$ & $(0.14)$ \\
\hline Main Geographical Controls & Yes & Yes & Yes & Yes & Yes & Yes \\
\hline Population Density (1700) & Yes & Yes & Yes & Yes & Yes & Yes \\
\hline GDP per capita (2000-2010) & Yes & Yes & Yes & Yes & Yes & Yes \\
\hline First-stage F-statistic & & & & 49.97 & 49.97 & 49.97 \\
\hline Adjusted- $R^{2}$ & 0.59 & 0.51 & 0.62 & 0.58 & 0.49 & 0.61 \\
\hline Observations & 88 & 88 & 88 & 88 & 88 & 88 \\
\hline
\end{tabular}

Notes: Standardized coefficients from Ordinary Least Squares (OLS) and Instrumental Variables (IV) regressions. Heteroskedasticity robust standard error estimates are reported in parentheses; *** denotes statistical significance at the $1 \%$ level, ${ }^{* *}$ at the $5 \%$ level, and $*$ at the $10 \%$ level, all for two-sided hypothesis tests.

Table B.12: Placebo - Neolithic Revolution and Non-Immune Mediated Deaths (2000-2013)

\begin{tabular}{|c|c|c|c|c|c|c|c|c|c|}
\hline & \multicolumn{9}{|c|}{ Non-Immune Mediated (Death Rates per 100,000) } \\
\hline & \multicolumn{3}{|c|}{ Alcohol Abuse } & \multicolumn{3}{|c|}{ Accidents } & \multicolumn{3}{|c|}{ Falls } \\
\hline & All & Female & Male & All & Female & Male & All & Female & Male \\
\hline & $(1)$ & $(2)$ & $(3)$ & $(4)$ & $(5)$ & (6) & $(7)$ & $(8)$ & $(9)$ \\
\hline \multirow[t]{2}{*}{ Years Since Neolithic Revolution } & -0.06 & 0.19 & -0.12 & -0.08 & -0.04 & -0.10 & -0.24 & -0.26 & -0.20 \\
\hline & $(0.12)$ & $(0.14)$ & $(0.12)$ & $(0.15)$ & $(0.16)$ & $(0.14)$ & $(0.17)$ & $(0.19)$ & $(0.15)$ \\
\hline Main Geographical Controls & Yes & Yes & Yes & Yes & Yes & Yes & Yes & Yes & Yes \\
\hline Population Density (1700) & Yes & Yes & Yes & Yes & Yes & Yes & Yes & Yes & Yes \\
\hline GDP per capita (2000-2010) & Yes & Yes & Yes & Yes & Yes & Yes & Yes & Yes & Yes \\
\hline First-stage F-statistic & 50.19 & 50.19 & 50.19 & 50.19 & 50.19 & 50.19 & 49.97 & 49.97 & 49.97 \\
\hline Adjusted- $R^{2}$ & 0.53 & 0.46 & 0.52 & 0.58 & 0.48 & 0.61 & 0.47 & 0.32 & 0.53 \\
\hline Observations & 89 & 89 & 89 & 89 & 89 & 89 & 88 & 88 & 88 \\
\hline
\end{tabular}

Notes: Standardized coefficients from Instrumental Variables (IV) regression. Heteroskedasticity robust standard error estimates are reported in parentheses; $* * *$ denotes statistical significance at the $1 \%$ level, ** at the $5 \%$ level, and * at the $10 \%$ level, all for two-sided hypothesis tests. 


\section{B.3 Town-Level Results}

Table B.13: Neolithic Revolution and Town-Level Mortality from All, Infectious, and Waterborne Diseases (1900)

\begin{tabular}{|c|c|c|c|c|c|c|}
\hline \multirow[t]{3}{*}{ Panel A: All } & \multicolumn{6}{|c|}{$\begin{array}{c}\text { Mortality Rate across Towns (1900) } \\
\text { All Diseases }\end{array}$} \\
\hline & \multicolumn{2}{|c|}{ OLS } & \multicolumn{2}{|c|}{ Reduced Form } & \multicolumn{2}{|c|}{ IV } \\
\hline & (1) & $(2)$ & $(3)$ & $(4)$ & $(5)$ & $(6)$ \\
\hline Years Since Neolithic Revolution & $\begin{array}{c}-0.20 * * \\
(0.08)\end{array}$ & $\begin{array}{c}-0.20 * * * \\
(0.07)\end{array}$ & $\begin{array}{c}-0.18^{* * *} \\
(0.06)\end{array}$ & $\begin{array}{c}-0.28 * * * \\
(0.07)\end{array}$ & $\begin{array}{c}-0.30 * * * \\
(0.10)\end{array}$ & $\begin{array}{c}-0.41^{* * *} \\
(0.12)\end{array}$ \\
\hline Main Geographical Controls & No & Yes & No & Yes & No & Yes \\
\hline Population & No & Yes & No & Yes & No & Yes \\
\hline Distance Fresnes & No & Yes & No & Yes & No & Yes \\
\hline First-stage F-statistic & & & & & 65.57 & 35.70 \\
\hline Adjusted- $R^{2}$ & 0.04 & 0.06 & 0.03 & 0.06 & 0.03 & 0.02 \\
\hline Observations & 593 & 593 & 593 & 593 & 593 & 593 \\
\hline \multirow[t]{3}{*}{ Panel B: Airborne } & \multicolumn{6}{|c|}{$\begin{array}{l}\text { Mortality Rate across Towns (1900) } \\
\text { Infectious Diseases (Airborne) }\end{array}$} \\
\hline & \multicolumn{2}{|c|}{ OLS } & \multicolumn{2}{|c|}{ Reduced Form } & \multicolumn{2}{|c|}{ IV } \\
\hline & (1) & $(2)$ & $(3)$ & $(4)$ & $(5)$ & (6) \\
\hline Years Since Neolithic Revolution & $\begin{array}{r}-0.20^{*} \\
(0.11)\end{array}$ & $\begin{array}{c}-0.15^{* *} \\
(0.07)\end{array}$ & $\begin{array}{c}-0.14^{* *} \\
(0.06)\end{array}$ & $\begin{array}{c}-0.21^{* * *} \\
(0.07)\end{array}$ & $\begin{array}{c}-0.23^{* *} \\
(0.09)\end{array}$ & $\begin{array}{c}-0.31^{* * *} \\
(0.10)\end{array}$ \\
\hline Main Geographical Controls & No & Yes & No & Yes & No & Yes \\
\hline Population & No & Yes & No & Yes & No & Yes \\
\hline Distance Fresnes & No & Yes & No & Yes & No & Yes \\
\hline First-stage F-statistic & & & & & 65.57 & 35.70 \\
\hline Adjusted- $R^{2}$ & 0.04 & 0.11 & 0.02 & 0.11 & 0.04 & 0.09 \\
\hline Observations & 593 & 593 & 593 & 593 & 593 & 593 \\
\hline \multirow[t]{3}{*}{ Panel C: Waterborne - Placebo } & \multicolumn{6}{|c|}{$\begin{array}{l}\text { Mortality Rate across Towns (1900) } \\
\text { Infectious Diseases (Waterborne) }\end{array}$} \\
\hline & \multicolumn{2}{|c|}{ OLS } & \multicolumn{2}{|c|}{ Reduced Form } & \multicolumn{2}{|c|}{ IV } \\
\hline & (1) & $(2)$ & $(3)$ & $(4)$ & $(5)$ & $(6)$ \\
\hline Years Since Neolithic Revolution & $\begin{array}{l}-0.05 \\
(0.08)\end{array}$ & $\begin{array}{c}0.09 \\
(0.06)\end{array}$ & $\begin{array}{l}-0.09 \\
(0.13)\end{array}$ & $\begin{array}{c}0.10 \\
(0.11)\end{array}$ & $\begin{array}{l}-0.14 \\
(0.22)\end{array}$ & $\begin{array}{c}0.15 \\
(0.15)\end{array}$ \\
\hline Main Geographical Controls & No & Yes & No & Yes & No & Yes \\
\hline Population & No & Yes & No & Yes & No & Yes \\
\hline Distance Fresnes & No & Yes & No & Yes & No & Yes \\
\hline First-stage F-statistic & & & & & 65.57 & 35.70 \\
\hline Adjusted- $R^{2}$ & 0.00 & 0.16 & 0.01 & 0.15 & -0.01 & 0.15 \\
\hline Observations & 593 & 593 & 593 & 593 & 593 & 593 \\
\hline
\end{tabular}

Notes: Standardized coefficients from Ordinary Least Squares (OLS) and Instrumental Variables (IV) regressions. Heteroskedasticity robust standard error estimates clustered at the département level are reported in parentheses; $* * *$ denotes statistical significance at the $1 \%$ level, $* *$ at the $5 \%$ level, and * at the $10 \%$ level, all for two-sided hypothesis tests. 
Table B.14: Neolithic Revolution and Town-Level Mortality (1900)

\begin{tabular}{|c|c|c|c|c|c|c|c|c|c|c|}
\hline & \multicolumn{10}{|c|}{ Mortality Rate across Towns (1900) } \\
\hline & & & & & & & Place & ebo & & \\
\hline & \multicolumn{2}{|c|}{ All Diseases } & \multicolumn{2}{|c|}{ Infectious (Air) } & \multicolumn{2}{|c|}{$\begin{array}{c}\text { Infectious } \\
\text { (Water) }\end{array}$} & \multicolumn{2}{|c|}{ Suicides } & \multicolumn{2}{|c|}{$\begin{array}{l}\text { Violent } \\
\text { Deaths }\end{array}$} \\
\hline & (1) & $(2)$ & $(3)$ & $(4)$ & $(5)$ & $(6)$ & $(7)$ & (8) & (9) & $(10)$ \\
\hline Years Since Neolithic Revolution & $\begin{array}{c}-0.40^{* * *} \\
(0.12)\end{array}$ & $\begin{array}{c}-0.69 * * * \\
(0.23)\end{array}$ & $\begin{array}{c}-0.34^{* * *} \\
(0.10)\end{array}$ & $\begin{array}{c}-0.59^{* * *} \\
(0.18)\end{array}$ & $\begin{array}{c}0.14 \\
(0.16)\end{array}$ & $\begin{array}{c}0.07 \\
(0.30)\end{array}$ & $\begin{array}{c}0.10 \\
(0.12)\end{array}$ & $\begin{array}{c}0.12 \\
(0.19)\end{array}$ & $\begin{array}{l}-0.07 \\
(0.09)\end{array}$ & $\begin{array}{c}0.04 \\
(0.17)\end{array}$ \\
\hline Main Geographical Controls & Yes & Yes & Yes & Yes & Yes & Yes & Yes & Yes & Yes & Yes \\
\hline Population & Yes & Yes & Yes & Yes & Yes & Yes & Yes & Yes & Yes & Yes \\
\hline Distance to Fresnes & Yes & Yes & Yes & Yes & Yes & Yes & Yes & Yes & Yes & Yes \\
\hline département Level Development Controls & No & Yes & No & Yes & No & Yes & No & Yes & No & Yes \\
\hline First-stage F-statistic & 33.44 & 13.05 & 33.44 & 13.05 & 33.44 & 13.05 & 33.44 & 13.05 & 33.44 & 13.05 \\
\hline Observations & 588 & 588 & 588 & 588 & 588 & 588 & 588 & 588 & 588 & 588 \\
\hline
\end{tabular}




\section{B.4 Individual-Level Results}

Table B.15: Neolithic Revolution and General Health Status

\begin{tabular}{|c|c|c|c|c|c|c|}
\hline & \multicolumn{6}{|c|}{ General Health Status } \\
\hline & \multicolumn{2}{|c|}{ All } & \multicolumn{2}{|c|}{ Non-Migrants } & \multicolumn{2}{|r|}{ French Non-Migrants } \\
\hline & (1) & $(2)$ & $(3)$ & $(4)$ & $(5)$ & (6) \\
\hline Years Since Neolithic Revolution & $\begin{array}{l}0.06 * * * \\
(0.02)\end{array}$ & $\begin{array}{l}0.05^{* * *} \\
(0.02)\end{array}$ & $\begin{array}{l}0.05^{* * *} \\
(0.02)\end{array}$ & $\begin{array}{l}0.04^{* * *} \\
(0.02)\end{array}$ & $\begin{array}{l}0.06 * * * \\
(0.02)\end{array}$ & $\begin{array}{l}0.05^{* * *} \\
(0.02)\end{array}$ \\
\hline Geographical Controls & Yes & Yes & Yes & Yes & Yes & Yes \\
\hline Individual Controls & No & Yes & No & Yes & No & Yes \\
\hline First-stage F-statistic & 160.86 & 161.27 & 148.09 & 148.40 & 150.07 & 150.45 \\
\hline Adjusted- $R^{2}$ & 0.01 & 0.16 & 0.01 & 0.16 & 0.01 & 0.16 \\
\hline Observations & 8926 & 8926 & 5049 & 5049 & 4381 & 4381 \\
\hline
\end{tabular}

Notes: Standardized coefficients from Instrumental Variables (IV) regressions. Heteroskedasticity robust standard error estimates clustered at the Départment of residence are reported in parentheses; ${ }^{* * *}$ denotes statistical significance at the $1 \%$ level, ${ }^{* *}$ at the $5 \%$ level, and * at the $10 \%$ level, all for two-sided hypothesis tests.

Table B.16: Neolithic Revolution and General Health Status (Good or Very Good)

\begin{tabular}{|c|c|c|c|c|c|c|}
\hline & \multicolumn{6}{|c|}{ General Health Status (Good or Very Good) } \\
\hline & \multicolumn{2}{|c|}{ All } & \multicolumn{2}{|c|}{ Non-Migrants } & \multicolumn{2}{|r|}{ French Non-Migrants } \\
\hline & $(1)$ & $(2)$ & $(3)$ & $(4)$ & $(5)$ & $(6)$ \\
\hline \multirow[t]{2}{*}{ Years Since Neolithic Revolution } & $0.06 * * *$ & $0.06 * * *$ & $0.06^{* * *}$ & $0.06 * * *$ & $0.07 * * *$ & $0.06 * * *$ \\
\hline & $(0.02)$ & $(0.01)$ & $(0.02)$ & $(0.02)$ & $(0.02)$ & $(0.02)$ \\
\hline Geographical Controls & Yes & Yes & Yes & Yes & Yes & Yes \\
\hline Individual Controls & No & Yes & No & Yes & No & Yes \\
\hline First-stage F-statistic & 160.86 & 161.27 & 148.09 & 148.40 & 150.07 & 150.45 \\
\hline Adjusted- $R^{2}$ & 0.01 & 0.14 & 0.00 & 0.14 & 0.01 & 0.14 \\
\hline Observations & 8926 & 8926 & 5049 & 5049 & 4381 & 4381 \\
\hline
\end{tabular}

Notes: Standardized coefficients from Instrumental Variables (IV) regressions. Heteroskedasticity robust standard error estimates clustered at the Départment of residence are reported in parentheses; ${ }^{* * *}$ denotes statistical significance at the $1 \%$ level, $* *$ at the $5 \%$ level, and $*$ at the $10 \%$ level, all for two-sided hypothesis tests. 
Table B.17: Neolithic Revolution and Chronic Health Condition

\begin{tabular}{|c|c|c|c|c|c|c|}
\hline & \multicolumn{6}{|c|}{ Individual Suffers Long-Standing Illness or Chronic Condition } \\
\hline & \multicolumn{2}{|c|}{ All } & \multicolumn{2}{|c|}{ Non-Migrants } & \multicolumn{2}{|r|}{ French Non-Migrants } \\
\hline & (1) & $(2)$ & $(3)$ & $(4)$ & $(5)$ & (6) \\
\hline \multirow[t]{2}{*}{ Years Since Neolithic Revolution } & $0.04^{* * *}$ & $0.04^{* * *}$ & $0.04^{* *}$ & $0.03^{*}$ & $0.05^{* * *}$ & $0.04^{*}$ \\
\hline & $(0.02)$ & $(0.01)$ & $(0.02)$ & $(0.02)$ & $(0.02)$ & $(0.02)$ \\
\hline Geographical Controls & Yes & Yes & Yes & Yes & Yes & Yes \\
\hline Individual Controls & No & Yes & No & Yes & No & Yes \\
\hline First-stage F-statistic & 160.86 & 161.27 & 148.09 & 148.40 & 150.07 & 150.45 \\
\hline Adjusted- $R^{2}$ & 0.00 & 0.10 & 0.00 & 0.11 & 0.00 & 0.10 \\
\hline Observations & 8926 & 8926 & 5049 & 5049 & 4381 & 4381 \\
\hline
\end{tabular}

Notes: Standardized coefficients from Instrumental Variables (IV) regressions. Heteroskedasticity robust standard error estimates clustered at the Départment of residence are reported in parentheses; ${ }^{* * *}$ denotes statistical significance at the $1 \%$ level, ${ }^{* *}$ at the $5 \%$ level, and * at the $10 \%$ level, all for two-sided hypothesis tests.

Table B.18: Neolithic Revolution and Health Related Disability

\begin{tabular}{|c|c|c|c|c|c|c|}
\hline & \multicolumn{6}{|c|}{ Individual Has Health Related Limitation or Disability } \\
\hline & \multicolumn{2}{|c|}{ All } & \multicolumn{2}{|c|}{ Non-Migrants } & \multicolumn{2}{|r|}{ French Non-Migrants } \\
\hline & (1) & $(2)$ & $(3)$ & $(4)$ & $(5)$ & $(6)$ \\
\hline \multirow[t]{2}{*}{ Years Since Neolithic Revolution } & $0.03^{*}$ & $0.03^{*}$ & $0.05^{* *}$ & $0.04^{* *}$ & $0.05^{* * *}$ & $0.05^{* *}$ \\
\hline & $(0.02)$ & $(0.02)$ & $(0.02)$ & $(0.02)$ & $(0.02)$ & $(0.02)$ \\
\hline Geographical Controls & Yes & Yes & Yes & Yes & Yes & Yes \\
\hline Individual Controls & No & Yes & No & Yes & No & Yes \\
\hline First-stage F-statistic & 160.86 & 161.27 & 148.09 & 148.40 & 150.07 & 150.45 \\
\hline Adjusted- $R^{2}$ & 0.01 & 0.10 & 0.01 & 0.10 & 0.01 & 0.10 \\
\hline Observations & 8926 & 8926 & 5049 & 5049 & 4381 & 4381 \\
\hline
\end{tabular}

Notes: Standardized coefficients from Instrumental Variables (IV) regressions. Heteroskedasticity robust standard error estimates clustered at the Départment of residence are reported in parentheses; *** denotes statistical significance at the $1 \%$ level, ** at the $5 \%$ level, and * at the $10 \%$ level, all for two-sided hypothesis tests. 
Table B.19: Neolithic Revolution and General Health Status

\begin{tabular}{|c|c|c|c|c|c|c|}
\hline & \multicolumn{6}{|c|}{ General Health Status } \\
\hline & \multicolumn{2}{|c|}{ All } & \multicolumn{2}{|c|}{ Non-Migrants } & \multicolumn{2}{|r|}{ French Non-Migrants } \\
\hline & (1) & $(2)$ & $(3)$ & $(4)$ & $(5)$ & $(6)$ \\
\hline Years Since Neolithic Revolution & $\begin{array}{l}0.06 * * * \\
(0.02)\end{array}$ & $\begin{array}{l}0.05^{* * *} \\
(0.02)\end{array}$ & $\begin{array}{l}0.04^{* *} \\
(0.02)\end{array}$ & $\begin{array}{l}0.03^{*} \\
(0.02)\end{array}$ & $\begin{array}{l}0.06^{* * *} \\
(0.02)\end{array}$ & $\begin{array}{l}0.04^{* *} \\
(0.02)\end{array}$ \\
\hline Geographical Controls & Yes & Yes & Yes & Yes & Yes & Yes \\
\hline Individual Controls & No & Yes & No & Yes & No & Yes \\
\hline First-stage F-statistic & 164.40 & 165.38 & 146.85 & 147.70 & 150.10 & 151.81 \\
\hline Adjusted- $R^{2}$ & 0.01 & 0.16 & 0.01 & 0.17 & 0.01 & 0.17 \\
\hline Observations & 8926 & 8926 & 5049 & 5049 & 4381 & 4381 \\
\hline
\end{tabular}

Notes: Standardized coefficients from Instrumental Variables (IV) regressions. Heteroskedasticity robust standard error estimates clustered at the Départment of residence are reported in parentheses; ${ }^{* * *}$ denotes statistical significance at the $1 \%$ level, ${ }^{* *}$ at the $5 \%$ level, and * at the $10 \%$ level, all for two-sided hypothesis tests.

Table B.20: Neolithic Revolution and General Health Status (Good or Very Good)

\begin{tabular}{|c|c|c|c|c|c|c|}
\hline & \multicolumn{6}{|c|}{ General Health Status (Good or Very Good) } \\
\hline & \multicolumn{2}{|c|}{ All } & \multicolumn{2}{|c|}{ Non-Migrants } & \multicolumn{2}{|r|}{ French Non-Migrants } \\
\hline & $(1)$ & $(2)$ & $(3)$ & $(4)$ & $(5)$ & $(6)$ \\
\hline Years Since Neolithic Revolution & $\begin{array}{l}0.06 * * * \\
(0.02)\end{array}$ & $\begin{array}{l}0.06 \text { *** } \\
(0.02)\end{array}$ & $\begin{array}{l}0.06 * * * \\
(0.02)\end{array}$ & $\begin{array}{l}0.05^{* * *} \\
(0.02)\end{array}$ & $\begin{array}{l}0.07 * * * \\
(0.02)\end{array}$ & $\begin{array}{l}0.06^{* * *} \\
(0.02)\end{array}$ \\
\hline Geographical Controls & Yes & Yes & Yes & Yes & Yes & Yes \\
\hline Individual Controls & No & Yes & No & Yes & No & Yes \\
\hline First-stage F-statistic & 164.40 & 165.38 & 146.85 & 147.70 & 150.10 & 151.81 \\
\hline Adjusted- $R^{2}$ & 0.01 & 0.14 & 0.01 & 0.15 & 0.01 & 0.15 \\
\hline Observations & 8926 & 8926 & 5049 & 5049 & 4381 & 4381 \\
\hline
\end{tabular}

Notes: Standardized coefficients from Instrumental Variables (IV) regressions. Heteroskedasticity robust standard error estimates clustered at the Départment of residence are reported in parentheses; *** denotes statistical significance at the $1 \%$ level, ** at the $5 \%$ level, and * at the $10 \%$ level, all for two-sided hypothesis tests. 
Table B.21: Neolithic Revolution and Chronic Health Condition

\begin{tabular}{|c|c|c|c|c|c|c|}
\hline & \multicolumn{6}{|c|}{ Individual Suffers Long-Standing Illness or Chronic Condition } \\
\hline & \multicolumn{2}{|c|}{ All } & \multicolumn{2}{|c|}{ Non-Migrants } & \multicolumn{2}{|r|}{ French Non-Migrants } \\
\hline & (1) & $(2)$ & $(3)$ & $(4)$ & $(5)$ & $(6)$ \\
\hline \multirow[t]{2}{*}{ Years Since Neolithic Revolution } & $0.04^{* *}$ & $0.03^{* * *}$ & 0.03 & 0.02 & $0.03^{*}$ & 0.02 \\
\hline & $(0.01)$ & $(0.01)$ & $(0.02)$ & $(0.02)$ & $(0.02)$ & $(0.02)$ \\
\hline Geographical Controls & Yes & Yes & Yes & Yes & Yes & Yes \\
\hline Individual Controls & No & Yes & No & Yes & No & Yes \\
\hline First-stage F-statistic & 164.40 & 165.38 & 146.85 & 147.70 & 150.10 & 151.81 \\
\hline Adjusted- $R^{2}$ & 0.00 & 0.10 & 0.00 & 0.11 & 0.00 & 0.11 \\
\hline Observations & 8926 & 8926 & 5049 & 5049 & 4381 & 4381 \\
\hline
\end{tabular}

Notes: Standardized coefficients from Instrumental Variables (IV) regressions. Heteroskedasticity robust standard error estimates clustered at the Départment of residence are reported in parentheses; ${ }^{* * *}$ denotes statistical significance at the $1 \%$ level, ${ }^{* *}$ at the $5 \%$ level, and * at the $10 \%$ level, all for two-sided hypothesis tests.

Table B.22: Neolithic Revolution and Health Related Disability

\begin{tabular}{|c|c|c|c|c|c|c|}
\hline & \multicolumn{6}{|c|}{ Individual Has Health Related Limitation or Disability } \\
\hline & \multicolumn{2}{|c|}{ All } & \multicolumn{2}{|c|}{ Non-Migrants } & \multicolumn{2}{|r|}{ French Non-Migrants } \\
\hline & (1) & $(2)$ & $(3)$ & (4) & $(5)$ & (6) \\
\hline \multirow[t]{2}{*}{ Years Since Neolithic Revolution } & $0.04^{* *}$ & $0.04^{* *}$ & $0.05^{* * *}$ & $0.05^{* *}$ & $0.06^{* * *}$ & $0.05^{* *}$ \\
\hline & $(0.02)$ & $(0.02)$ & $(0.02)$ & $(0.02)$ & $(0.02)$ & $(0.02)$ \\
\hline Geographical Controls & Yes & Yes & Yes & Yes & Yes & Yes \\
\hline Individual Controls & No & Yes & No & Yes & No & Yes \\
\hline First-stage F-statistic & 164.40 & 165.38 & 146.85 & 147.70 & 150.10 & 151.81 \\
\hline Adjusted- $R^{2}$ & 0.01 & 0.10 & 0.01 & 0.10 & 0.01 & 0.10 \\
\hline Observations & 8926 & 8926 & 5049 & 5049 & 4381 & 4381 \\
\hline
\end{tabular}

Notes: Standardized coefficients from Instrumental Variables (IV) regressions. Heteroskedasticity robust standard error estimates clustered at the Départment of residence are reported in parentheses; *** denotes statistical significance at the $1 \%$ level, ** at the $5 \%$ level, and * at the $10 \%$ level, all for two-sided hypothesis tests. 


\section{Robustness}

\section{C.1 Robustness to Migration}

Table C.1: Neolithic Revolution and Life Expectancy

Robustness: Share of Native Population

\begin{tabular}{|c|c|c|c|c|c|c|c|c|}
\hline & \multicolumn{8}{|c|}{ Log Life Expectancy } \\
\hline & \multicolumn{2}{|c|}{1871} & \multicolumn{2}{|c|}{1901} & \multicolumn{2}{|c|}{1952} & \multicolumn{2}{|r|}{2013} \\
\hline & $(1)$ & $(2)$ & $(3)$ & (4) & $(5)$ & (6) & $(7)$ & (8) \\
\hline \multirow[t]{2}{*}{ Years Since Neolithic Revolution } & $0.60 * * *$ & $0.59 * * *$ & $0.27^{* *}$ & $0.32^{* *}$ & -0.03 & -0.04 & $-0.91^{* * *}$ & $-0.94^{* * *}$ \\
\hline & $(0.20)$ & $(0.17)$ & $(0.13)$ & $(0.13)$ & $(0.14)$ & $(0.13)$ & $(0.19)$ & $(0.19)$ \\
\hline \multirow[t]{2}{*}{ Share born in dept. (1872) } & -0.09 & & $0.32^{* *}$ & & -0.08 & & $-0.28^{* * *}$ & \\
\hline & $(0.20)$ & & $(0.12)$ & & $(0.13)$ & & $(0.11)$ & \\
\hline \multirow[t]{2}{*}{ Share born in dept. (1901) } & & -0.21 & & $0.19^{*}$ & & -0.10 & & $-0.34^{* * *}$ \\
\hline & & $(0.14)$ & & $(0.11)$ & & $(0.10)$ & & $(0.12)$ \\
\hline Main Geographical Controls & Yes & Yes & Yes & Yes & Yes & Yes & Yes & Yes \\
\hline Population Density (1700) & Yes & Yes & Yes & Yes & Yes & Yes & Yes & Yes \\
\hline First-stage F-statistic & 57.43 & 58.31 & 57.43 & 58.31 & 57.88 & 59.03 & 57.43 & 58.31 \\
\hline Adjusted- $R^{2}$ & 0.22 & 0.24 & 0.62 & 0.60 & 0.56 & 0.56 & 0.40 & 0.41 \\
\hline Observations & 86 & 86 & 86 & 86 & 85 & 85 & 86 & 86 \\
\hline
\end{tabular}

Notes: Standardized coefficients from Ordinary Least Squares (OLS) and Instrumental Variables (IV) regressions. Heteroskedasticity robust standard error estimates are reported in parentheses; *** denotes statistical significance at the $1 \%$ level, ${ }^{* *}$ at the $5 \%$ level, and * at the $10 \%$ level, all for two-sided hypothesis tests. 
Table C.2: Neolithic Revolution and Life Expectancy

Robustness: Share of Native Population

\begin{tabular}{|c|c|c|c|c|c|c|c|}
\hline & \multicolumn{7}{|c|}{ Log Life Expectancy } \\
\hline & 1968 & 1975 & 1982 & 1990 & 1999 & & 2013 \\
\hline & $(1)$ & $(2)$ & $(3)$ & $(4)$ & $(5)$ & & $(6)$ \\
\hline Years Since Neolithic Revolution & $\begin{array}{l}-0.50^{* * *} \\
(0.13)\end{array}$ & $\begin{array}{l}-0.71^{* * *} \\
(0.12)\end{array}$ & $\begin{array}{l}-0.77^{* * *} \\
(0.11)\end{array}$ & $\begin{array}{l}-0.94^{* * *} \\
(0.14)\end{array}$ & $\begin{array}{l}-0.98^{* * *} \\
(0.15)\end{array}$ & $\begin{array}{l}-0.87^{* * *} \\
(0.17)\end{array}$ & \\
\hline Share born in dept. (1968) & $\begin{array}{l}-0.09 \\
(0.08)\end{array}$ & & & & & & \\
\hline Share born in dept. (1975) & & $\begin{array}{l}-0.10 \\
(0.07)\end{array}$ & & & & & \\
\hline Share born in dept. (1982) & & & $\begin{array}{l}-0.16^{*} \\
(0.10)\end{array}$ & & & & \\
\hline Share born in dept. (1990) & & & & $\begin{array}{l}-0.05 \\
(0.11)\end{array}$ & & & \\
\hline Share born in dept. (1999) & & & & & $\begin{array}{l}-0.03 \\
(0.11)\end{array}$ & & \\
\hline Share born in dept. (2013) & & & & & & $\begin{array}{l}-0.12 \\
(0.10)\end{array}$ & \\
\hline Main Geographical Controls & Yes & Yes & Yes & Yes & Yes & Yes & \\
\hline Population Density (1700) & Yes & Yes & Yes & Yes & Yes & Yes & \\
\hline First-stage F-statistic & 49.62 & 48.74 & 46.54 & 45.77 & 44.49 & 42.72 & \\
\hline Adjusted- $R^{2}$ & 0.49 & 0.55 & 0.58 & 0.46 & 0.31 & 0.40 & \\
\hline Observations & 88 & 88 & 88 & 89 & 89 & 89 & \\
\hline
\end{tabular}

Notes: Standardized coefficients from Ordinary Least Squares (OLS) and Instrumental Variables (IV) regressions. Heteroskedasticity robust standard error estimates are reported in parentheses; *** denotes statistical significance at the $1 \%$ level, $* *$ at the $5 \%$ level, and * at the $10 \%$ level, all for two-sided hypothesis tests. 


\section{C.2 Robustness to Lagged Life Expectancy}

Table C.3: Neolithic Revolution and Life Expectancy

\begin{tabular}{|c|c|c|c|c|c|c|c|c|}
\hline & \multicolumn{8}{|c|}{ Log Life Expectancy } \\
\hline & \multicolumn{2}{|c|}{1952} & \multicolumn{2}{|c|}{1982} & \multicolumn{2}{|c|}{1995} & \multicolumn{2}{|r|}{2013} \\
\hline & (1) & $(2)$ & $(3)$ & (4) & (5) & (6) & (7) & (8) \\
\hline Years Since Neolithic Revolution & $\begin{array}{l}0.02 \\
(0.13)\end{array}$ & $\begin{array}{l}-0.15 \\
(0.14)\end{array}$ & $\begin{array}{l}-0.76^{* * *} \\
(0.11)\end{array}$ & $\begin{array}{l}-0.88^{* * *} \\
(0.12)\end{array}$ & $\begin{array}{l}-0.93^{* * *} \\
(0.14)\end{array}$ & $\begin{array}{l}-1.01^{* * *} \\
(0.16)\end{array}$ & $\begin{array}{l}-0.95^{* * *} \\
(0.18)\end{array}$ & $\begin{array}{l}-0.93^{* * *} \\
(0.19)\end{array}$ \\
\hline Log Life Expectancy (1871-75) & $\begin{array}{l}-0.11 \\
(0.09)\end{array}$ & & $\begin{array}{l}-0.06 \\
(0.09)\end{array}$ & & $\begin{array}{l}-0.04 \\
(0.07)\end{array}$ & & $\begin{array}{l}-0.03 \\
(0.09)\end{array}$ & \\
\hline Log Life Expectancy (1901-05) & & $\begin{array}{l}0.31^{* *} \\
(0.12)\end{array}$ & & $\begin{array}{l}0.26^{* *} \\
(0.13)\end{array}$ & & $\begin{array}{l}0.15 \\
(0.13)\end{array}$ & & $\begin{array}{l}-0.10 \\
(0.15)\end{array}$ \\
\hline Main Geographical Controls & Yes & Yes & Yes & Yes & Yes & Yes & Yes & Yes \\
\hline Population Density (1700) & Yes & Yes & Yes & Yes & Yes & Yes & Yes & Yes \\
\hline First-stage F-statistic & 49.57 & 47.13 & 49.57 & 47.13 & 49.92 & 47.95 & 49.92 & 47.95 \\
\hline Adjusted- $R^{2}$ & 0.57 & 0.59 & 0.56 & 0.52 & 0.51 & 0.47 & 0.35 & 0.37 \\
\hline Observations & 85 & 85 & 85 & 85 & 86 & 86 & 86 & 86 \\
\hline
\end{tabular}

Notes: Standardized coefficients from Ordinary Least Squares (OLS) and Instrumental Variables (IV) regressions. Heteroskedasticity robust standard error estimates are reported in parentheses; *** denotes statistical significance at the $1 \%$ level, ${ }^{* *}$ at the $5 \%$ level, and * at the $10 \%$ level, all for two-sided hypothesis tests. 


\section{C.3 Robustness to Population Age and Gender Structure}

Table C.4: Neolithic Revolution and Life Expectancy

Robustness: Share of Old People

\begin{tabular}{|c|c|c|c|c|c|c|c|}
\hline & \multicolumn{7}{|c|}{ Log Life Expectancy } \\
\hline & 1968 & 1975 & 1982 & 1990 & 1999 & & 2013 \\
\hline & $(1)$ & $(2)$ & $(3)$ & $(4)$ & $(5)$ & & (6) \\
\hline Years Since Neolithic Revolution & $\begin{array}{l}-0.60^{* * *} \\
(0.13)\end{array}$ & $\begin{array}{l}-0.79 * * * \\
(0.11)\end{array}$ & $\begin{array}{l}-0.83^{* * *} \\
(0.12)\end{array}$ & $\begin{array}{l}-0.96^{* * *} \\
(0.14)\end{array}$ & $\begin{array}{l}-0.98^{* * *} \\
(0.13)\end{array}$ & $\begin{array}{l}-0.93^{* * *} \\
(0.15)\end{array}$ & \\
\hline Share of population over 60 (1968) & $\begin{array}{l}0.33^{* * *} \\
(0.10)\end{array}$ & & & & & & \\
\hline Share of population over $60(1975)$ & & $\begin{array}{l}0.19^{*} \\
(0.10)\end{array}$ & & & & & \\
\hline Share of population over 60 (1982) & & & $\begin{array}{l}0.11 \\
(0.11)\end{array}$ & & & & \\
\hline Share of population over 60 (1990) & & & & $\begin{array}{l}-0.00 \\
(0.12)\end{array}$ & & & \\
\hline Share of population over 60 (1999) & & & & & $\begin{array}{l}-0.11 \\
(0.13)\end{array}$ & & \\
\hline Share of population over 60 (2010) & & & & & & $\begin{array}{l}-0.35^{* * *} \\
(0.10)\end{array}$ & \\
\hline Main Geographical Controls & Yes & Yes & Yes & Yes & Yes & Yes & \\
\hline Population Density (1700) & Yes & Yes & Yes & Yes & Yes & Yes & \\
\hline First-stage F-statistic & 45.00 & 44.98 & 45.95 & 47.45 & 50.76 & 53.16 & \\
\hline Adjusted- $R^{2}$ & 0.50 & 0.52 & 0.54 & 0.44 & 0.31 & 0.43 & \\
\hline Observations & 88 & 88 & 88 & 89 & 89 & 89 & \\
\hline
\end{tabular}

Notes: Standardized coefficients from Ordinary Least Squares (OLS) and Instrumental Variables (IV) regressions. Heteroskedasticity robust standard error estimates are reported in parentheses; *** denotes statistical significance at the $1 \%$ level, $* *$ at the $5 \%$ level, and * at the $10 \%$ level, all for two-sided hypothesis tests. 
Table C.5: Neolithic Revolution and Life Expectancy Robustness to Population Structure

\begin{tabular}{|c|c|c|c|c|c|c|c|}
\hline & \multicolumn{7}{|c|}{ Log Life Expectancy } \\
\hline & \multicolumn{2}{|c|}{1982} & \multicolumn{2}{|c|}{1999} & \multicolumn{3}{|c|}{2013} \\
\hline & $(1)$ & $(2)$ & $(3)$ & $(4)$ & $(5)$ & & $(6)$ \\
\hline Years Since Neolithic Revolution & $\begin{array}{l}-0.79^{* * *} \\
(0.11)\end{array}$ & $\begin{array}{l}-0.82^{* * *} \\
(0.11)\end{array}$ & $\begin{array}{l}-0.98^{* * *} \\
(0.15)\end{array}$ & $\begin{array}{l}-0.98^{* * *} \\
(0.14)\end{array}$ & $\begin{array}{l}-0.91^{* * *} \\
(0.17)\end{array}$ & $\begin{array}{l}-0.91^{* * *} \\
(0.16)\end{array}$ & \\
\hline Sex Ratio & $\begin{array}{l}-0.08 \\
(0.08)\end{array}$ & & $\begin{array}{l}-0.03 \\
(0.09)\end{array}$ & & $\begin{array}{l}-0.02 \\
(0.09)\end{array}$ & & \\
\hline Age Dependency & & $\begin{array}{l}-0.03 \\
(0.02)\end{array}$ & & $\begin{array}{l}0.03 \\
(0.02)\end{array}$ & & $\begin{array}{l}0.03 \\
(0.02)\end{array}$ & \\
\hline Main Geographical Controls & Yes & Yes & Yes & Yes & Yes & Yes & \\
\hline Population Density (1700) & Yes & Yes & Yes & Yes & Yes & Yes & \\
\hline First-stage F-statistic & 48.39 & 50.53 & 44.50 & 50.62 & 44.64 & 50.61 & \\
\hline Adjusted- $R^{2}$ & 0.56 & 0.54 & 0.31 & 0.30 & 0.37 & 0.37 & \\
\hline Observations & 88 & 88 & 89 & 89 & 89 & 89 & \\
\hline
\end{tabular}

Notes: Standardized coefficients from Ordinary Least Squares (OLS) and Instrumental Variables (IV) regressions. Heteroskedasticity robust standard error estimates are reported in parentheses; *** denotes statistical significance at the $1 \%$ level, $* *$ at the $5 \%$ level, and * at the $10 \%$ level, all for two-sided hypothesis tests. 


\section{C.4 Robustness to Clustering of Standard Errors and Spatial-Auto-correlation}

Table C.6: Neolithic Revolution and Life Expectancy (1871-1875)

\begin{tabular}{|c|c|c|c|c|c|c|}
\hline & \multicolumn{6}{|c|}{ Log Life Expectancy (1871-1875) } \\
\hline & \multicolumn{3}{|c|}{ OLS } & \multicolumn{3}{|c|}{ Reduced Form } \\
\hline & (1) & $(2)$ & $(3)$ & (4) & $(5)$ & (6) \\
\hline \multirow[t]{4}{*}{ Years Since Neolithic Revolution } & $0.54^{* * *}$ & $0.43^{* *}$ & $0.40^{* *}$ & $0.42^{* * *}$ & $0.46^{* * *}$ & $0.47^{* * *}$ \\
\hline & $(0.19)$ & $(0.17)$ & $(0.16)$ & $(0.13)$ & $(0.15)$ & $(0.15)$ \\
\hline & {$[0.11]$} & {$[0.08]$} & {$[0.07]$} & {$[0.16]$} & {$[0.14]$} & {$[0.14]$} \\
\hline & $\{0.13\}$ & $\{0.11\}$ & $\{0.11\}$ & $\{0.13\}$ & $\{0.14\}$ & $\{0.14\}$ \\
\hline Latitude & Yes & Yes & Yes & Yes & Yes & Yes \\
\hline Other Geographic Controls & No & Yes & Yes & No & Yes & Yes \\
\hline Population Density 1700 & No & No & Yes & No & No & Yes \\
\hline Adjusted- $R^{2}$ & 0.07 & 0.31 & 0.31 & 0.12 & 0.35 & 0.36 \\
\hline Observations & 86.00 & 86.00 & 86.00 & 86.00 & 86.00 & 86.00 \\
\hline
\end{tabular}

Notes: Standardized coefficients from Ordinary Least Squares (OLS). Heteroskedasticity robust standard error estimates in parenthesis, spatial auto-correlation corrected standard error estimates following Conley (1999) in squared brackets and Cliff-Ord ML in curly brackets.; *** denotes statistical significance at the $1 \%$ level, ${ }^{* *}$ at the $5 \%$ level, and ${ }^{*}$ at the $10 \%$ level, all for two-sided hypothesis tests.

Table C.7: Neolithic Revolution and Life Expectancy (2013)

\begin{tabular}{|c|c|c|c|c|c|c|}
\hline & \multicolumn{6}{|c|}{ Log Life Expectancy (2013) } \\
\hline & \multicolumn{3}{|c|}{ OLS } & \multicolumn{3}{|c|}{ Reduced Form } \\
\hline & (1) & $(2)$ & $(3)$ & $(4)$ & $(5)$ & (6) \\
\hline \multirow[t]{4}{*}{ Years Since Neolithic Revolution } & $-0.76^{* * *}$ & $-0.88 * * *$ & $-0.86^{* * *}$ & $-0.36^{* * *}$ & $-0.73^{* * *}$ & $-0.73^{* * *}$ \\
\hline & $(0.20)$ & $(0.20)$ & $(0.21)$ & $(0.10)$ & $(0.12)$ & $(0.12)$ \\
\hline & {$[0.13]$} & {$[0.11]$} & {$[0.11]$} & {$[0.11]$} & {$[0.10]$} & {$[0.10]$} \\
\hline & $\{0.10\}$ & $\{0.09\}$ & $\{0.09\}$ & $\{0.11\}$ & $\{0.12\}$ & $\{0.11\}$ \\
\hline Latitude & Yes & Yes & Yes & Yes & Yes & Yes \\
\hline Other Geographic Controls & No & Yes & Yes & No & Yes & Yes \\
\hline Population Density 1700 & No & No & Yes & No & No & Yes \\
\hline Adjusted- $R^{2}$ & 0.38 & 0.50 & 0.50 & 0.35 & 0.54 & 0.54 \\
\hline Observations & 89.00 & 89.00 & 89.00 & 89.00 & 89.00 & 89.00 \\
\hline
\end{tabular}

Notes: Standardized coefficients from Ordinary Least Squares (OLS). Heteroskedasticity robust standard error estimates in parenthesis, spatial auto-correlation corrected standard error estimates following Conley (1999) in squared brackets and Cliff-Ord ML in curly brackets.; *** denotes statistical significance at the $1 \%$ level, $* *$ at the $5 \%$ level, and $*$ at the $10 \%$ level, all for two-sided hypothesis tests. 
Table C.8: Neolithic Revolution and Life Expectancy (1871-1875)

\begin{tabular}{|c|c|c|c|c|c|c|c|c|c|}
\hline & \multicolumn{9}{|c|}{ Log Life Expectancy (1871-1875) } \\
\hline & \multicolumn{3}{|c|}{ OLS } & \multicolumn{3}{|c|}{ Reduced Form } & \multicolumn{3}{|c|}{ IV } \\
\hline & (1) & (2) & (3) & $(4)$ & (5) & (6) & (7) & (8) & $(9)$ \\
\hline Years Since Neolithic Revolution & $\begin{array}{l}0.30^{* *} \\
(0.14)\end{array}$ & $\begin{array}{l}0.24^{* *} \\
(0.09)\end{array}$ & $\begin{array}{l}0.23^{* *} \\
(0.09)\end{array}$ & $\begin{array}{l}0.42^{* *} \\
(0.18)\end{array}$ & $\begin{array}{l}0.46^{\text {*** }} \\
(0.14)\end{array}$ & $\begin{array}{l}0.47^{* * *} \\
(0.14)\end{array}$ & $\begin{array}{l}0.79^{* *} \\
(0.34)\end{array}$ & $\begin{array}{l}0.57^{* * *} \\
(0.19)\end{array}$ & $\begin{array}{l}0.58^{* * *} \\
(0.18)\end{array}$ \\
\hline Latitude & $\begin{array}{l}0.38^{* * *} \\
(0.12)\end{array}$ & $\begin{array}{l}0.09 \\
(0.36)\end{array}$ & $\begin{array}{l}0.18 \\
(0.35)\end{array}$ & $\begin{array}{l}0.46^{* * *} \\
(0.12)\end{array}$ & $\begin{array}{l}-0.20 \\
(0.33)\end{array}$ & $\begin{array}{l}-0.07 \\
(0.30)\end{array}$ & $\begin{array}{l}0.68^{* * *} \\
(0.23)\end{array}$ & $\begin{array}{l}0.32 \\
(0.29)\end{array}$ & $\begin{array}{l}0.40 \\
(0.30)\end{array}$ \\
\hline Agricultural Suitability & & $\begin{array}{l}0.18 \\
(0.13)\end{array}$ & $\begin{array}{l}0.14 \\
(0.12)\end{array}$ & & $\begin{array}{l}0.02 \\
(0.15)\end{array}$ & $\begin{array}{l}-0.02 \\
(0.14)\end{array}$ & & $\begin{array}{l}0.19 \\
(0.12)\end{array}$ & $\begin{array}{l}0.16 \\
(0.12)\end{array}$ \\
\hline Caloric Suitability (pre-1500CE) & & $\begin{array}{l}0.02 \\
(0.15)\end{array}$ & $\begin{array}{l}0.02 \\
(0.15)\end{array}$ & & $\begin{array}{l}-0.05 \\
(0.14)\end{array}$ & $\begin{array}{l}-0.05 \\
(0.14)\end{array}$ & & $\begin{array}{l}0.02 \\
(0.13)\end{array}$ & $\begin{array}{l}0.02 \\
(0.13)\end{array}$ \\
\hline Elevation & & $\begin{array}{l}-0.13 \\
(0.63)\end{array}$ & $\begin{array}{l}-0.04 \\
(0.62)\end{array}$ & & $\begin{array}{l}-0.99 \\
(0.68)\end{array}$ & $\begin{array}{l}-0.90 \\
(0.67)\end{array}$ & & $\begin{array}{l}-0.15 \\
(0.63)\end{array}$ & $\begin{array}{l}-0.08 \\
(0.64)\end{array}$ \\
\hline Ruggedness & & $\begin{array}{l}0.09 \\
(0.28)\end{array}$ & $\begin{array}{l}0.16 \\
(0.29)\end{array}$ & & $\begin{array}{l}-0.01 \\
(0.24)\end{array}$ & $\begin{array}{l}0.08 \\
(0.25)\end{array}$ & & $\begin{array}{l}0.08 \\
(0.22)\end{array}$ & $\begin{array}{l}0.13 \\
(0.23)\end{array}$ \\
\hline Precipitation (Avg.) & & $\begin{array}{l}-0.51 \\
(0.32)\end{array}$ & $\begin{array}{l}-0.46 \\
(0.33)\end{array}$ & & $\begin{array}{l}-1.12^{* * *} \\
(0.39)\end{array}$ & $\begin{array}{l}-1.07^{* *} \\
(0.40)\end{array}$ & & $\begin{array}{l}-0.54 \\
(0.35)\end{array}$ & $\begin{array}{l}-0.50 \\
(0.36)\end{array}$ \\
\hline Precipitation Volatility & & $\begin{array}{l}0.13 \\
(0.40)\end{array}$ & $\begin{array}{l}0.05 \\
(0.41)\end{array}$ & & $\begin{array}{l}0.62 \\
(0.45)\end{array}$ & $\begin{array}{l}0.54 \\
(0.45)\end{array}$ & & $\begin{array}{l}0.20 \\
(0.40)\end{array}$ & $\begin{array}{l}0.15 \\
(0.43)\end{array}$ \\
\hline Temperature (Avg.) & & $\begin{array}{l}-0.09 \\
(0.38)\end{array}$ & $\begin{array}{l}0.09 \\
(0.36)\end{array}$ & & $\begin{array}{l}-0.96^{*} \\
(0.50)\end{array}$ & $\begin{array}{l}-0.77 \\
(0.48)\end{array}$ & & $\begin{array}{l}-0.08 \\
(0.39)\end{array}$ & $\begin{array}{l}0.06 \\
(0.43)\end{array}$ \\
\hline Temperature Volatility & & $\begin{array}{l}0.10 \\
(0.17)\end{array}$ & $\begin{array}{l}0.13 \\
(0.17)\end{array}$ & & $\begin{array}{l}-0.07 \\
(0.15)\end{array}$ & $\begin{array}{l}-0.04 \\
(0.15)\end{array}$ & & $\begin{array}{l}0.09 \\
(0.15)\end{array}$ & $\begin{array}{l}0.11 \\
(0.15)\end{array}$ \\
\hline Access to Sea & & $\begin{array}{l}-0.12 \\
(0.13)\end{array}$ & $\begin{array}{l}-0.12 \\
(0.13)\end{array}$ & & $\begin{array}{l}-0.14 \\
(0.14)\end{array}$ & $\begin{array}{l}-0.13 \\
(0.14)\end{array}$ & & $\begin{array}{l}-0.08 \\
(0.14)\end{array}$ & $\begin{array}{l}-0.08 \\
(0.14)\end{array}$ \\
\hline Coast Length & & $\begin{array}{l}-0.16^{*} \\
(0.08)\end{array}$ & $\begin{array}{l}-0.16^{*} \\
(0.08)\end{array}$ & & $\begin{array}{l}-0.16^{*} \\
(0.08)\end{array}$ & $\begin{array}{l}-0.16^{*} \\
(0.08)\end{array}$ & & $\begin{array}{l}-0.17^{*} \\
(0.09)\end{array}$ & $\begin{array}{l}-0.17^{*} \\
(0.09)\end{array}$ \\
\hline Potential Pre-industrial Immobility & & $\begin{array}{l}0.10 \\
(0.12)\end{array}$ & $\begin{array}{l}0.05 \\
(0.13)\end{array}$ & & $\begin{array}{l}0.07 \\
(0.13)\end{array}$ & $\begin{array}{l}0.00 \\
(0.13)\end{array}$ & & $\begin{array}{l}0.09 \\
(0.11)\end{array}$ & $\begin{array}{l}0.05 \\
(0.13)\end{array}$ \\
\hline Population Density (1700) & & & $\begin{array}{l}-0.13 \\
(0.13)\end{array}$ & & & $\begin{array}{l}-0.17 \\
(0.13)\end{array}$ & & & $\begin{array}{l}-0.10 \\
(0.12)\end{array}$ \\
\hline First-stage F-statistic & & & & & & & 49.27 & 51.20 & 51.21 \\
\hline Adjusted- $R^{2}$ & 0.07 & 0.31 & 0.31 & 0.12 & 0.35 & 0.36 & -0.08 & 0.24 & 0.23 \\
\hline Observations & 86 & 86 & 86 & 86 & 86 & 86 & 86 & 86 & 86 \\
\hline
\end{tabular}

Notes: Standardized coefficients from Ordinary Least Squares (OLS) and Instrumental Variables (IV) regressions. Heteroskedasticity robust standard error estimates clustered at the region level are reported in parentheses; *** denotes statistical significance at the $1 \%$ level, ${ }^{* *}$ at the $5 \%$ level, and $*$ at the $10 \%$ level, all for two-sided hypothesis tests. 
Table C.9: Neolithic Revolution and Life Expectancy (2013)

\begin{tabular}{|c|c|c|c|c|c|c|c|c|c|}
\hline & \multicolumn{9}{|c|}{ Log Life Expectancy (2013) } \\
\hline & \multicolumn{3}{|c|}{ OLS } & \multicolumn{3}{|c|}{ Reduced Form } & \multicolumn{3}{|c|}{ IV } \\
\hline & (1) & (2) & (3) & $(4)$ & (5) & (6) & (7) & (8) & (9) \\
\hline Years Since Neolithic Revolution & $\begin{array}{l}-0.43^{* * *} \\
(0.14)\end{array}$ & $\begin{array}{l}-0.50^{* * *} \\
(0.12)\end{array}$ & $\begin{array}{l}-0.49^{* * *} \\
(0.12)\end{array}$ & $\begin{array}{l}-0.36^{* * *} \\
(0.12)\end{array}$ & $\begin{array}{l}-0.73^{* * *} \\
(0.10)\end{array}$ & $\begin{array}{l}-0.73^{* * *} \\
(0.10)\end{array}$ & $\begin{array}{l}-0.68^{* * *} \\
(0.24)\end{array}$ & $\begin{array}{l}-0.92^{* * *} \\
(0.16)\end{array}$ & $\begin{array}{l}-0.92^{* * *} \\
(0.16)\end{array}$ \\
\hline Latitude & $\begin{array}{l}-0.79^{* * *} \\
(0.17)\end{array}$ & $\begin{array}{l}-0.74^{*} \\
(0.37)\end{array}$ & $\begin{array}{l}-0.79^{* *} \\
(0.36)\end{array}$ & $\begin{array}{l}-0.75^{* * *} \\
(0.16)\end{array}$ & $\begin{array}{l}-0.24 \\
(0.39)\end{array}$ & $\begin{array}{l}-0.34 \\
(0.35)\end{array}$ & $\begin{array}{l}-0.95^{* * *} \\
(0.20)\end{array}$ & $\begin{array}{l}-1.00^{* *} \\
(0.39)\end{array}$ & $\begin{array}{l}-1.03^{* * *} \\
(0.40)\end{array}$ \\
\hline Agricultural Suitability & & $\begin{array}{l}-0.30^{* *} \\
(0.14)\end{array}$ & $\begin{array}{l}-0.28^{*} \\
(0.14)\end{array}$ & & $\begin{array}{l}-0.06 \\
(0.13)\end{array}$ & $\begin{array}{l}-0.03 \\
(0.13)\end{array}$ & & $\begin{array}{l}-0.32^{* *} \\
(0.14)\end{array}$ & $\begin{array}{l}-0.31^{* *} \\
(0.14)\end{array}$ \\
\hline Caloric Suitability (pre-1500CE) & & $\begin{array}{l}-0.13 \\
(0.14)\end{array}$ & $\begin{array}{l}-0.14 \\
(0.14)\end{array}$ & & $\begin{array}{l}-0.04 \\
(0.12)\end{array}$ & $\begin{array}{l}-0.05 \\
(0.11)\end{array}$ & & $\begin{array}{l}-0.15 \\
(0.16)\end{array}$ & $\begin{array}{l}-0.15 \\
(0.16)\end{array}$ \\
\hline Elevation & & $\begin{array}{l}-1.01 \\
(0.86)\end{array}$ & $\begin{array}{l}-1.06 \\
(0.84)\end{array}$ & & $\begin{array}{l}0.26 \\
(0.78)\end{array}$ & $\begin{array}{l}0.18 \\
(0.74)\end{array}$ & & $\begin{array}{l}-0.92 \\
(0.92)\end{array}$ & $\begin{array}{l}-0.94 \\
(0.92)\end{array}$ \\
\hline Ruggedness & & $\begin{array}{l}0.69^{*} \\
(0.34)\end{array}$ & $\begin{array}{l}0.65^{*} \\
(0.34)\end{array}$ & & $\begin{array}{l}0.87^{* * *} \\
(0.24)\end{array}$ & $\begin{array}{l}0.80^{* * *} \\
(0.22)\end{array}$ & & $\begin{array}{l}0.69^{*} \\
(0.37)\end{array}$ & $\begin{array}{l}0.67^{*} \\
(0.37)\end{array}$ \\
\hline Precipitation (Avg.) & & $\begin{array}{l}-0.54 \\
(0.45)\end{array}$ & $\begin{array}{l}-0.57 \\
(0.44)\end{array}$ & & $\begin{array}{l}0.39 \\
(0.38)\end{array}$ & $\begin{array}{l}0.34 \\
(0.37)\end{array}$ & & $\begin{array}{l}-0.52 \\
(0.49)\end{array}$ & $\begin{array}{l}-0.53 \\
(0.49)\end{array}$ \\
\hline Precipitation Volatility & & $\begin{array}{l}0.63 \\
(0.40)\end{array}$ & $\begin{array}{l}0.68^{*} \\
(0.39)\end{array}$ & & $\begin{array}{l}-0.12 \\
(0.38)\end{array}$ & $\begin{array}{l}-0.05 \\
(0.36)\end{array}$ & & $\begin{array}{l}0.53 \\
(0.48)\end{array}$ & $\begin{array}{l}0.55 \\
(0.48)\end{array}$ \\
\hline Temperature (Avg.) & & $\begin{array}{l}-0.08 \\
(0.64)\end{array}$ & $\begin{array}{l}-0.19 \\
(0.62)\end{array}$ & & $\begin{array}{l}1.24^{*} \\
(0.69)\end{array}$ & $\begin{array}{l}1.08^{*} \\
(0.62)\end{array}$ & & $\begin{array}{l}-0.06 \\
(0.60)\end{array}$ & $\begin{array}{l}-0.10 \\
(0.61)\end{array}$ \\
\hline Temperature Volatility & & $\begin{array}{l}0.03 \\
(0.13)\end{array}$ & $\begin{array}{l}0.02 \\
(0.13)\end{array}$ & & $\begin{array}{l}0.37^{* *} \\
(0.15)\end{array}$ & $\begin{array}{l}0.35^{* *} \\
(0.15)\end{array}$ & & $\begin{array}{l}0.08 \\
(0.13)\end{array}$ & $\begin{array}{l}0.08 \\
(0.13)\end{array}$ \\
\hline Access to Sea & & $\begin{array}{l}-0.32^{* *} \\
(0.12)\end{array}$ & $\begin{array}{l}-0.32^{* *} \\
(0.13)\end{array}$ & & $\begin{array}{l}-0.27^{* *} \\
(0.11)\end{array}$ & $\begin{array}{l}-0.27^{* *} \\
(0.10)\end{array}$ & & $\begin{array}{l}-0.37^{* * *} \\
(0.13)\end{array}$ & $\begin{array}{l}-0.37^{* * *} \\
(0.13)\end{array}$ \\
\hline Coast Length & & $\begin{array}{c}-0.26^{*} \\
(0.13)\end{array}$ & $\begin{array}{l}-0.26^{*} \\
(0.13)\end{array}$ & & $\begin{array}{l}-0.25^{* *} \\
(0.10)\end{array}$ & $\begin{array}{l}-0.25^{* *} \\
(0.09)\end{array}$ & & $\begin{array}{l}-0.24^{*} \\
(0.14)\end{array}$ & $\begin{array}{l}-0.24^{*} \\
(0.14)\end{array}$ \\
\hline Potential Pre-industrial Immobility & & $\begin{array}{l}-0.10 \\
(0.08)\end{array}$ & $\begin{array}{l}-0.06 \\
(0.09)\end{array}$ & & $\begin{array}{l}-0.07 \\
(0.08)\end{array}$ & $\begin{array}{l}-0.02 \\
(0.07)\end{array}$ & & $\begin{array}{l}-0.08 \\
(0.10)\end{array}$ & $\begin{array}{l}-0.06 \\
(0.11)\end{array}$ \\
\hline Population Density (1700) & & & $\begin{array}{l}0.08 \\
(0.06)\end{array}$ & & & $\begin{array}{l}0.13^{* *} \\
(0.06)\end{array}$ & & & $\begin{array}{l}0.03 \\
(0.06)\end{array}$ \\
\hline First-stage F-statistic & & & & & & & 35.91 & 41.09 & 41.11 \\
\hline Adjusted- $R^{2}$ & 0.38 & 0.50 & 0.50 & 0.35 & 0.54 & 0.54 & 0.34 & 0.38 & 0.37 \\
\hline Observations & 89 & 89 & 89 & 89 & 89 & 89 & 89 & 89 & 89 \\
\hline
\end{tabular}

Notes: Standardized coefficients from Ordinary Least Squares (OLS) and Instrumental Variables (IV) regressions. Heteroskedasticity robust standard error estimates clustered at the region level are reported in parentheses; *** denotes statistical significance at the $1 \%$ level, ${ }^{* *}$ at the $5 \%$ level, and ${ }^{*}$ at the $10 \%$ level, all for two-sided hypothesis tests. 


\section{C.5 Robustness to Geographical Conditions}

Table C.10: Neolithic Revolution and Life Expectancy (1871-1875).

Excluding Sites Geographically Similar to French Neolithic Sites

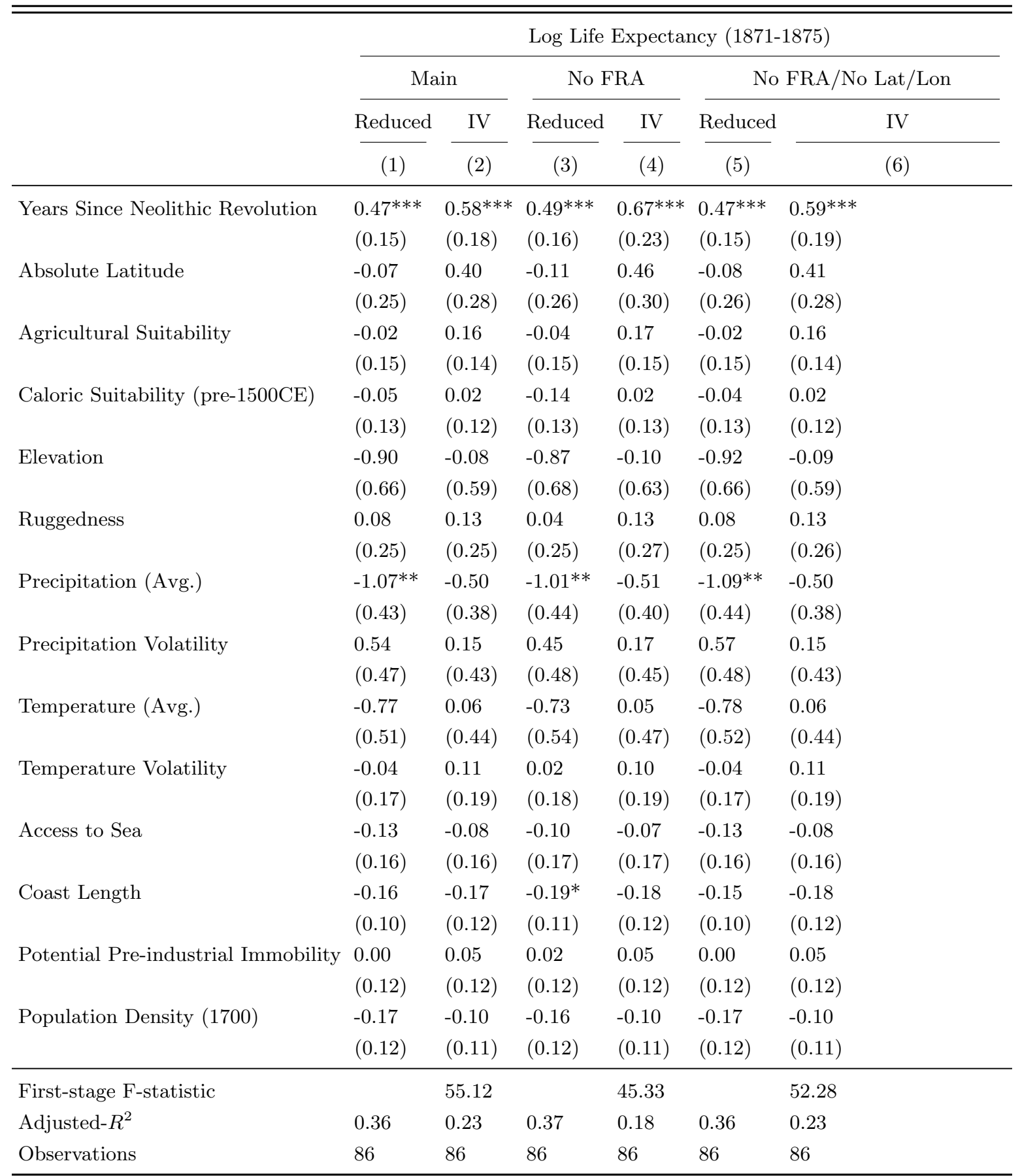

Notes: Standardized coefficients from Ordinary Least Squares (OLS) and Instrumental Variables (IV) regressions. Heteroskedasticity robust standard error estimates are reported in parentheses; ${ }^{* * *}$ denotes statistical significance at the $1 \%$ level, ** at the $5 \%$ level, and * at the $10 \%$ level, all for two-sided hypothesis tests. 
Table C.11: Neolithic Revolution and Life Expectancy (2013). Excluding Sites Geographically Similar to French Neolithic Sites

\begin{tabular}{|c|c|c|c|c|c|c|c|}
\hline & \multicolumn{7}{|c|}{ Log Life Expectancy (2013) } \\
\hline & \multicolumn{2}{|c|}{ Main } & \multicolumn{2}{|c|}{ No FRA } & \multicolumn{3}{|c|}{ No FRA/No Lat/Lon } \\
\hline & Reduced & IV & Reduced & IV & Reduced & & IV \\
\hline & $(1)$ & $(2)$ & $(3)$ & $(4)$ & $(5)$ & & (6) \\
\hline Years Since Neolithic Revolution & $\begin{array}{l}-0.73^{* * *} \\
(0.12)\end{array}$ & $\begin{array}{l}-0.92^{* * *} \\
(0.16)\end{array}$ & $\begin{array}{l}-0.66^{* * *} \\
(0.12)\end{array}$ & $\begin{array}{l}-0.93^{* * *} \\
(0.17)\end{array}$ & $\begin{array}{l}-0.73^{* * *} \\
(0.12)\end{array}$ & $\begin{array}{l}-0.94^{* * *} \\
(0.16)\end{array}$ & \\
\hline Absolute Latitude & $\begin{array}{l}-0.34 \\
(0.32)\end{array}$ & $\begin{array}{l}-1.03^{* *} \\
(0.45)\end{array}$ & $\begin{array}{l}-0.31 \\
(0.32)\end{array}$ & $\begin{array}{l}-1.03^{* *} \\
(0.45)\end{array}$ & $\begin{array}{l}-0.33 \\
(0.31)\end{array}$ & $\begin{array}{l}-1.03^{* *} \\
(0.45)\end{array}$ & \\
\hline Agricultural Suitability & $\begin{array}{l}-0.03 \\
(0.13)\end{array}$ & $\begin{array}{l}-0.31^{* *} \\
(0.13)\end{array}$ & $\begin{array}{l}-0.03 \\
(0.13)\end{array}$ & $\begin{array}{l}-0.31^{* *} \\
(0.13)\end{array}$ & $\begin{array}{l}-0.03 \\
(0.13)\end{array}$ & $\begin{array}{l}-0.31^{* *} \\
(0.13)\end{array}$ & \\
\hline Caloric Suitability (pre-1500CE) & $\begin{array}{l}-0.05 \\
(0.11)\end{array}$ & $\begin{array}{l}-0.15 \\
(0.16)\end{array}$ & $\begin{array}{l}0.06 \\
(0.12)\end{array}$ & $\begin{array}{l}-0.15 \\
(0.16)\end{array}$ & $\begin{array}{l}-0.06 \\
(0.11)\end{array}$ & $\begin{array}{l}-0.15 \\
(0.16)\end{array}$ & \\
\hline Elevation & $\begin{array}{l}0.18 \\
(0.65)\end{array}$ & $\begin{array}{l}-0.94 \\
(0.92)\end{array}$ & $\begin{array}{l}-0.05 \\
(0.64)\end{array}$ & $\begin{array}{l}-0.94 \\
(0.92)\end{array}$ & $\begin{array}{l}0.20 \\
(0.65)\end{array}$ & $\begin{array}{l}-0.94 \\
(0.93)\end{array}$ & \\
\hline Ruggedness & $\begin{array}{l}0.80^{* * *} \\
(0.20)\end{array}$ & $\begin{array}{l}0.67^{* *} \\
(0.33)\end{array}$ & $\begin{array}{l}0.84^{* * *} \\
(0.20)\end{array}$ & $\begin{array}{l}0.67^{* *} \\
(0.33)\end{array}$ & $\begin{array}{l}0.81^{* * *} \\
(0.20)\end{array}$ & $\begin{array}{l}0.67^{* *} \\
(0.33)\end{array}$ & \\
\hline Precipitation (Avg.) & $\begin{array}{l}0.34 \\
(0.32)\end{array}$ & $\begin{array}{l}-0.53 \\
(0.40)\end{array}$ & $\begin{array}{l}0.13 \\
(0.33)\end{array}$ & $\begin{array}{l}-0.53 \\
(0.40)\end{array}$ & $\begin{array}{l}0.36 \\
(0.32)\end{array}$ & $\begin{array}{l}-0.53 \\
(0.40)\end{array}$ & \\
\hline Precipitation Volatility & $\begin{array}{l}-0.05 \\
(0.35)\end{array}$ & $\begin{array}{l}0.55 \\
(0.44)\end{array}$ & $\begin{array}{l}0.19 \\
(0.36)\end{array}$ & $\begin{array}{l}0.55 \\
(0.45)\end{array}$ & $\begin{array}{l}-0.08 \\
(0.35)\end{array}$ & $\begin{array}{l}0.55 \\
(0.45)\end{array}$ & \\
\hline Temperature (Avg.) & $\begin{array}{l}1.08^{* *} \\
(0.54)\end{array}$ & $\begin{array}{l}-0.10 \\
(0.66)\end{array}$ & $\begin{array}{l}0.85 \\
(0.52)\end{array}$ & $\begin{array}{l}-0.10 \\
(0.66)\end{array}$ & $\begin{array}{l}1.09^{* *} \\
(0.53)\end{array}$ & $\begin{array}{l}-0.10 \\
(0.66)\end{array}$ & \\
\hline Temperature Volatility & $\begin{array}{l}0.35^{* *} \\
(0.17)\end{array}$ & $\begin{array}{l}0.08 \\
(0.16)\end{array}$ & $\begin{array}{l}0.24 \\
(0.17)\end{array}$ & $\begin{array}{l}0.08 \\
(0.16)\end{array}$ & $\begin{array}{l}0.36^{* *} \\
(0.17)\end{array}$ & $\begin{array}{l}0.08 \\
(0.16)\end{array}$ & \\
\hline Access to Sea & $\begin{array}{l}-0.27^{* *} \\
(0.13)\end{array}$ & $\begin{array}{l}-0.37^{* * *} \\
(0.12)\end{array}$ & $\begin{array}{l}-0.32^{* *} \\
(0.13)\end{array}$ & $\begin{array}{l}-0.37^{* * *} \\
(0.12)\end{array}$ & $\begin{array}{l}-0.28^{* *} \\
(0.13)\end{array}$ & $\begin{array}{l}-0.37^{* * *} \\
(0.13)\end{array}$ & \\
\hline Coast Length & $\begin{array}{l}-0.25^{* * *} \\
(0.09)\end{array}$ & $\begin{array}{c}-0.24^{*} \\
(0.13)\end{array}$ & $\begin{array}{l}-0.20^{* *} \\
(0.10)\end{array}$ & $\begin{array}{c}-0.24^{*} \\
(0.13)\end{array}$ & $\begin{array}{l}-0.25^{* * *} \\
(0.09)\end{array}$ & $\begin{array}{c}-0.24^{*} \\
(0.13)\end{array}$ & \\
\hline Potential Pre-industrial Immobility & $\begin{array}{l}-0.02 \\
(0.10)\end{array}$ & $\begin{array}{l}-0.06 \\
(0.09)\end{array}$ & $\begin{array}{l}-0.05 \\
(0.10)\end{array}$ & $\begin{array}{l}-0.06 \\
(0.09)\end{array}$ & $\begin{array}{l}-0.01 \\
(0.10)\end{array}$ & $\begin{array}{l}-0.06 \\
(0.09)\end{array}$ & \\
\hline Population Density (1700) & $\begin{array}{l}0.13 \\
(0.08)\end{array}$ & $\begin{array}{l}0.03 \\
(0.07)\end{array}$ & $\begin{array}{l}0.13 \\
(0.08)\end{array}$ & $\begin{array}{l}0.03 \\
(0.07)\end{array}$ & $\begin{array}{l}0.13 \\
(0.08)\end{array}$ & $\begin{array}{l}0.03 \\
(0.07)\end{array}$ & \\
\hline First-stage F-statistic & & 54.66 & & 44.54 & & 51.81 & \\
\hline Adjusted- $R^{2}$ & 0.54 & 0.37 & 0.52 & 0.37 & 0.54 & 0.36 & \\
\hline Observations & 89 & 89 & 89 & 89 & 89 & 89 & \\
\hline
\end{tabular}

Notes: Standardized coefficients from Ordinary Least Squares (OLS) and Instrumental Variables (IV) regressions. Heteroskedasticity robust standard error estimates are reported in parentheses; ${ }^{* * *}$ denotes statistical significance at the $1 \%$ level, ** at the $5 \%$ level, and * at the $10 \%$ level, all for two-sided hypothesis tests. 
C.6 Robustness to Interpolation Method 


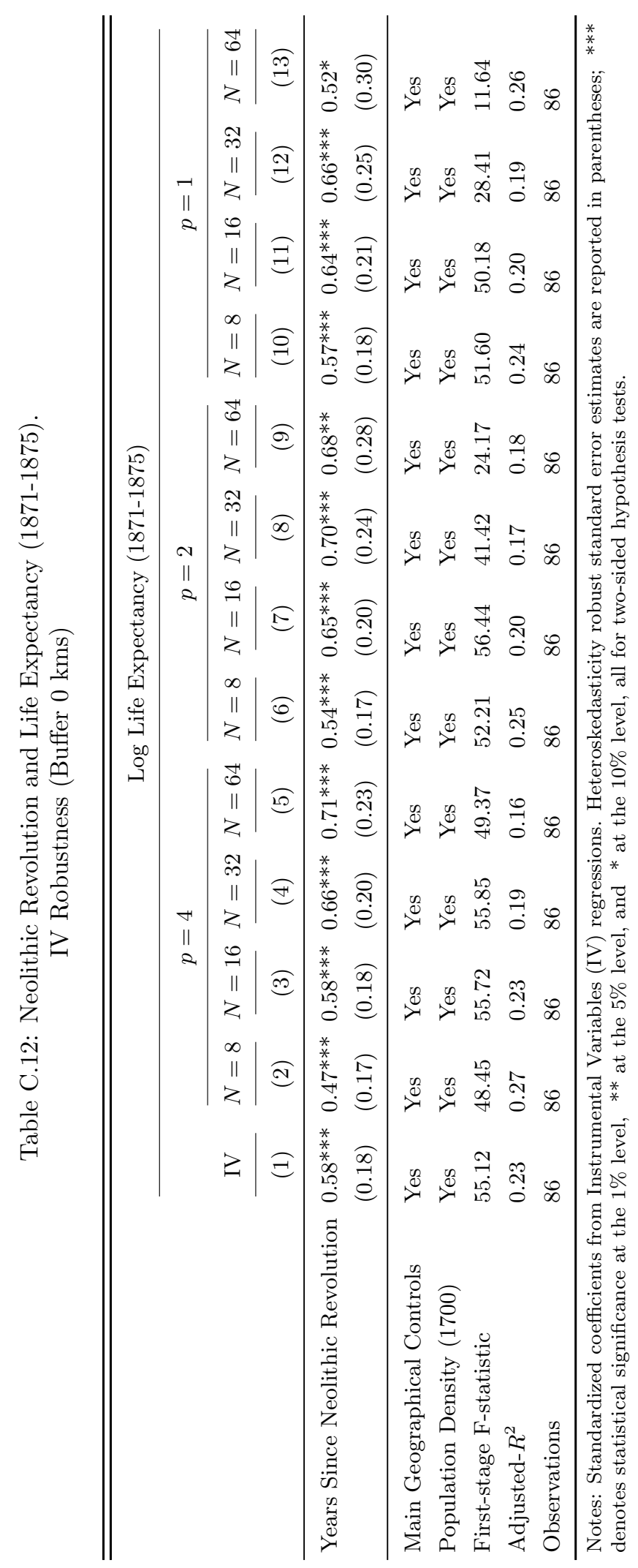




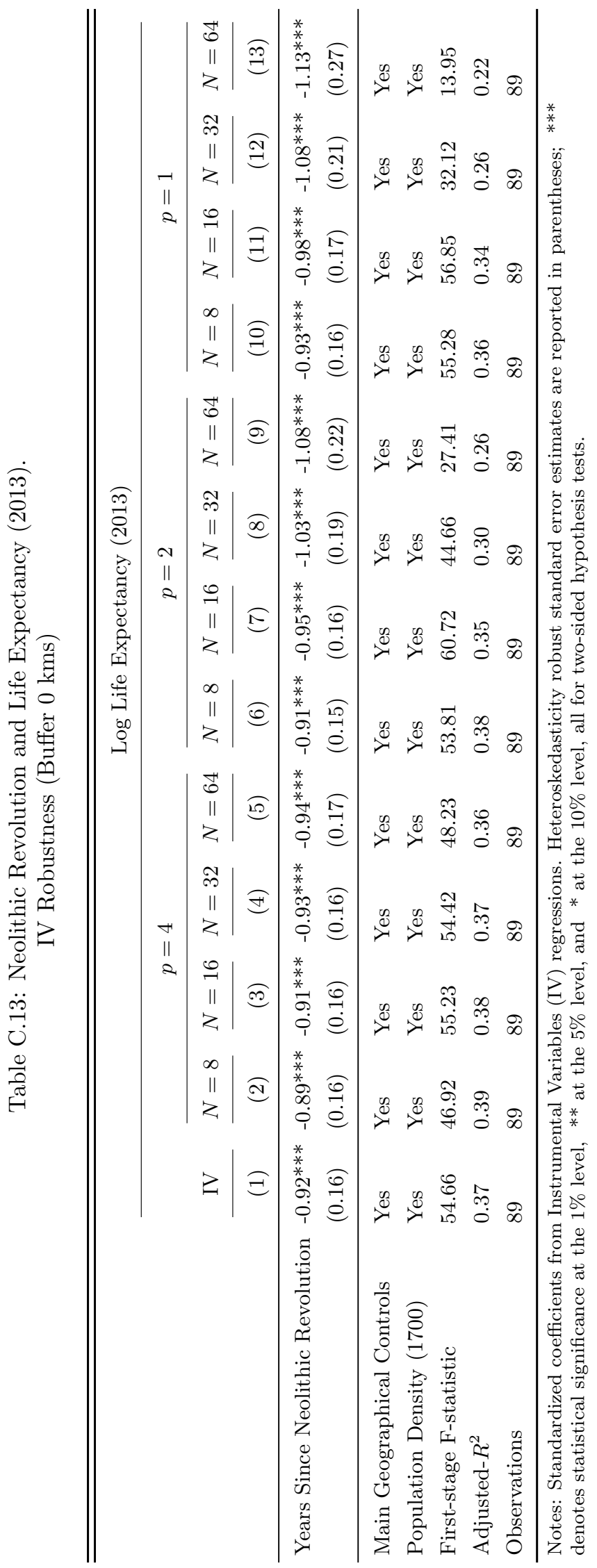




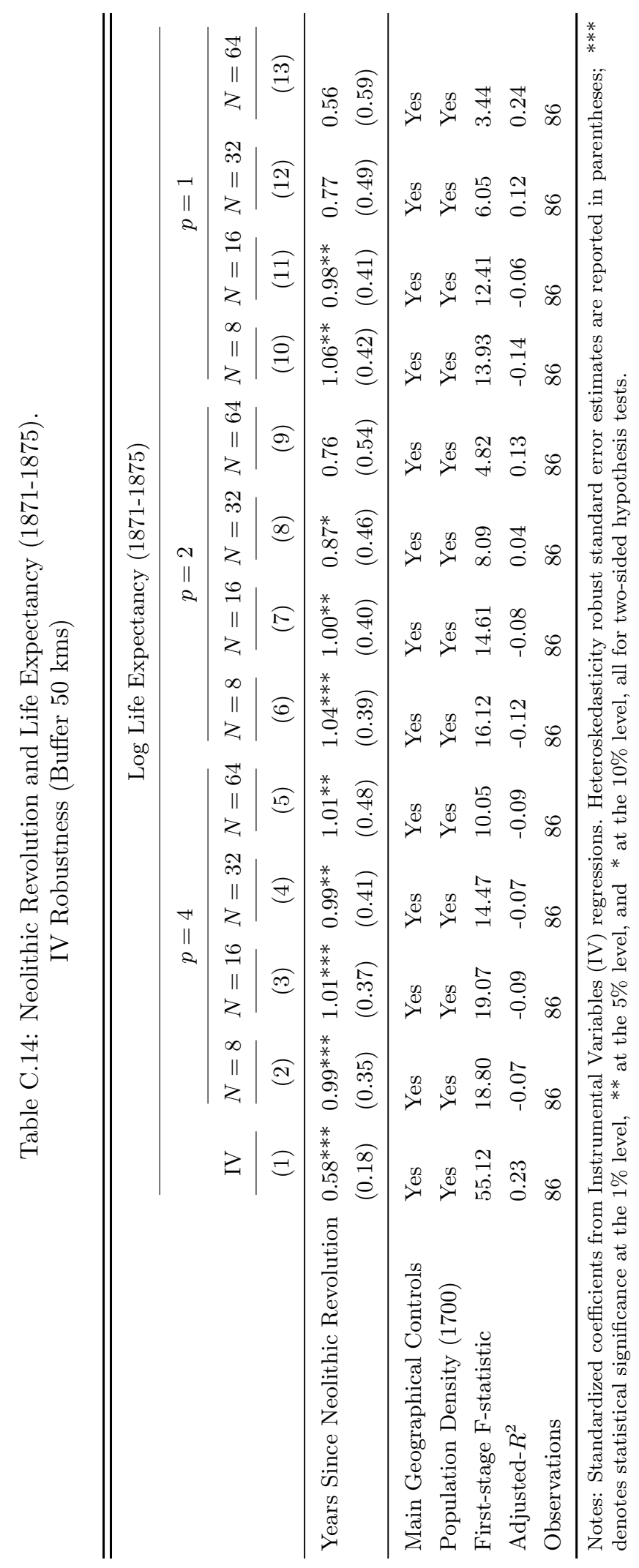




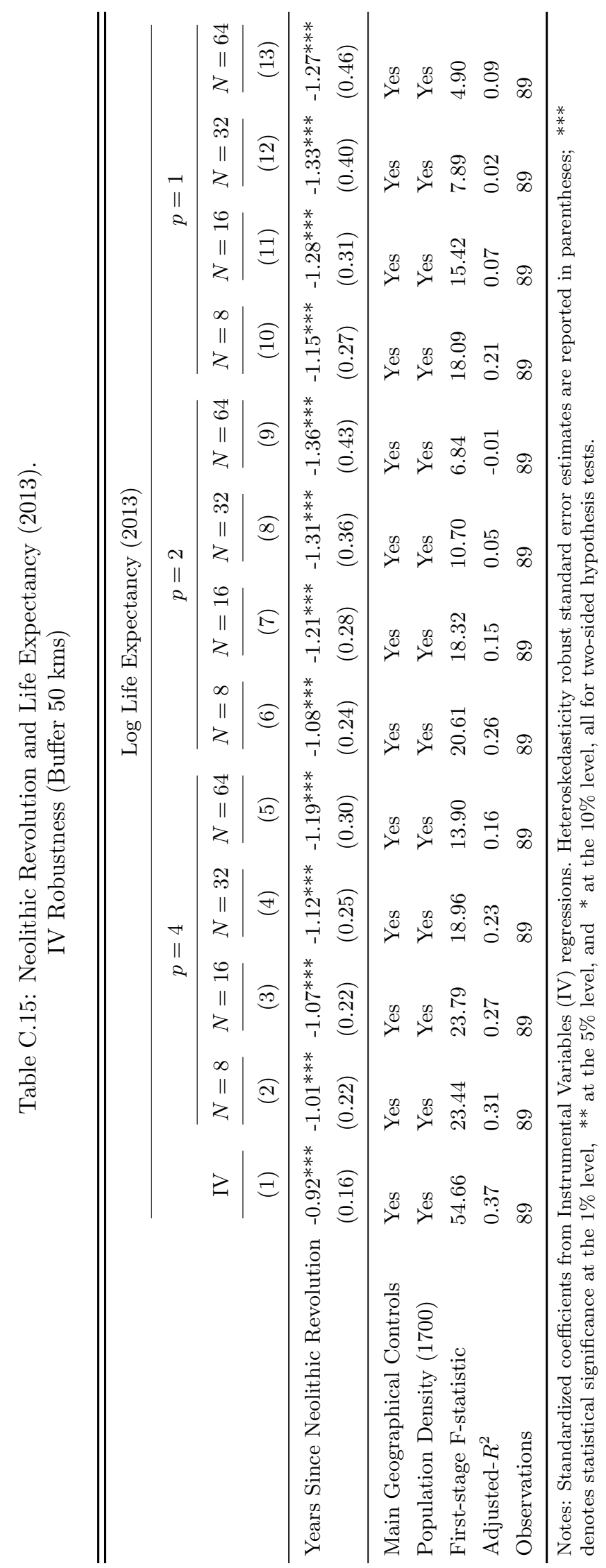




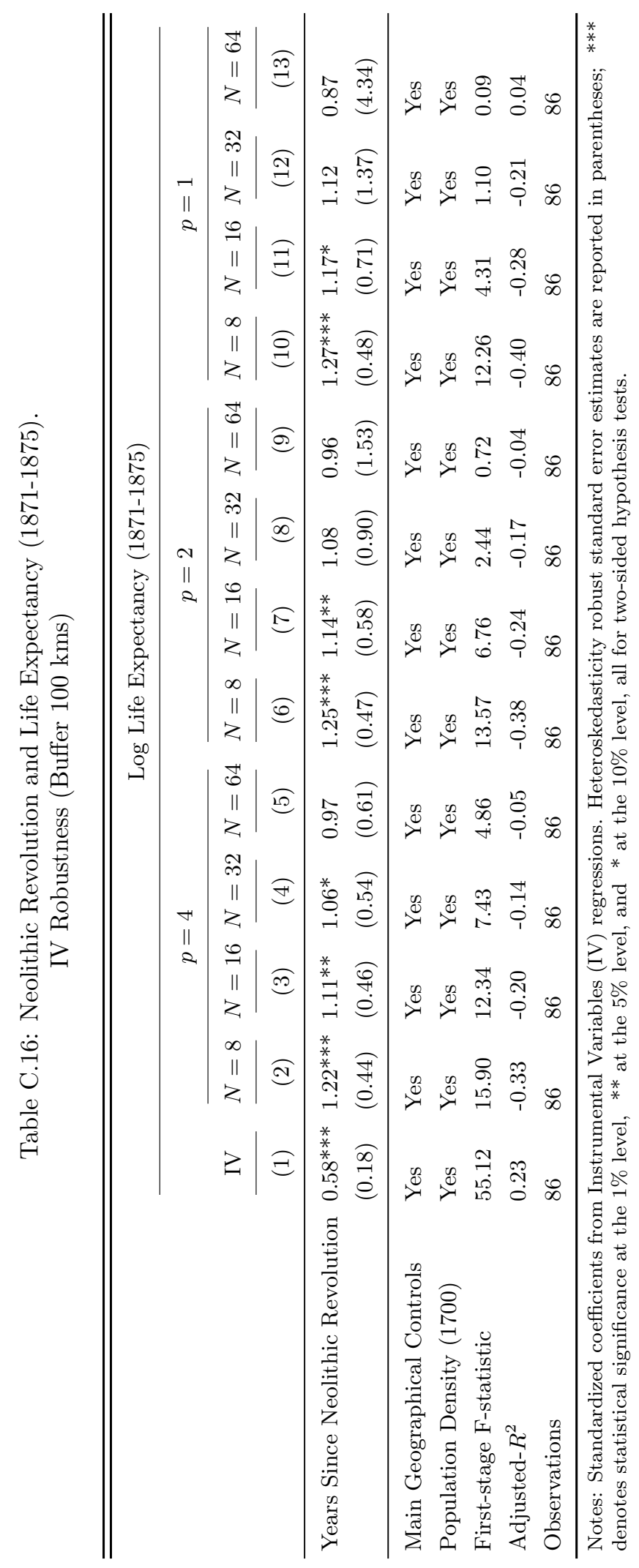




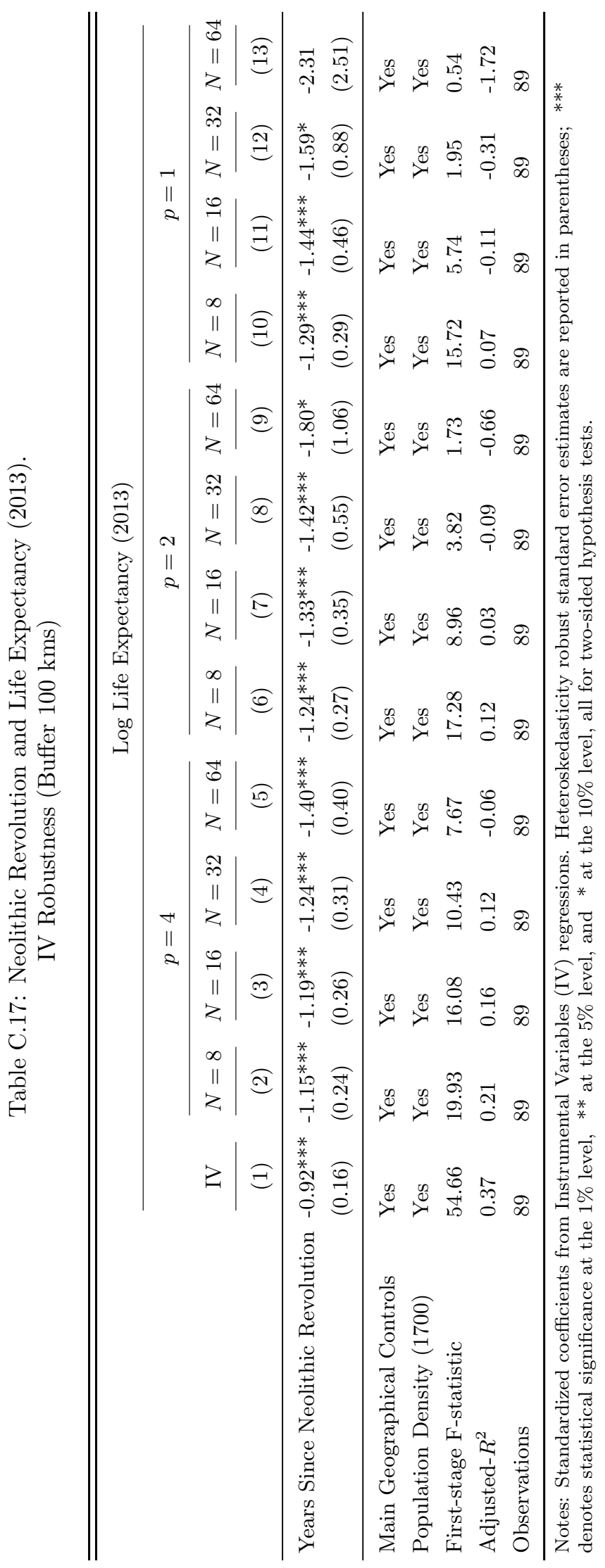




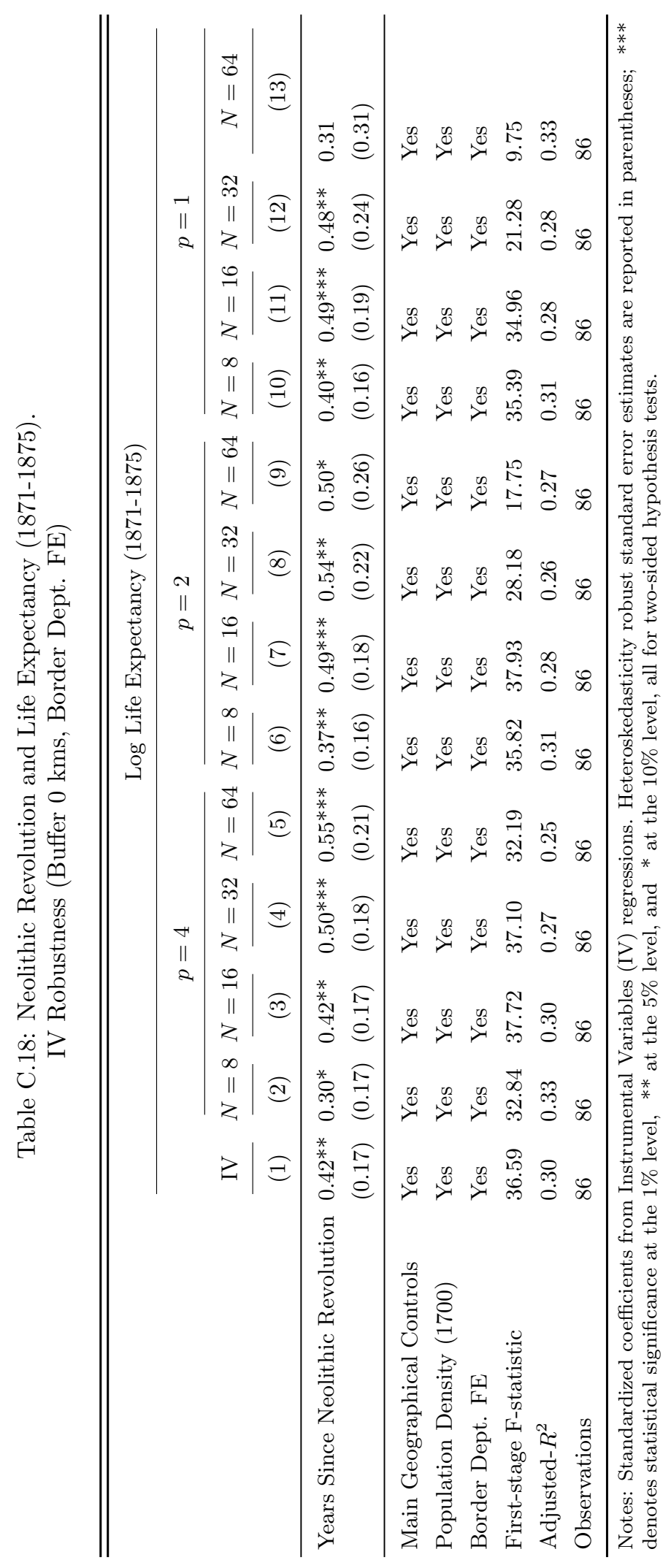




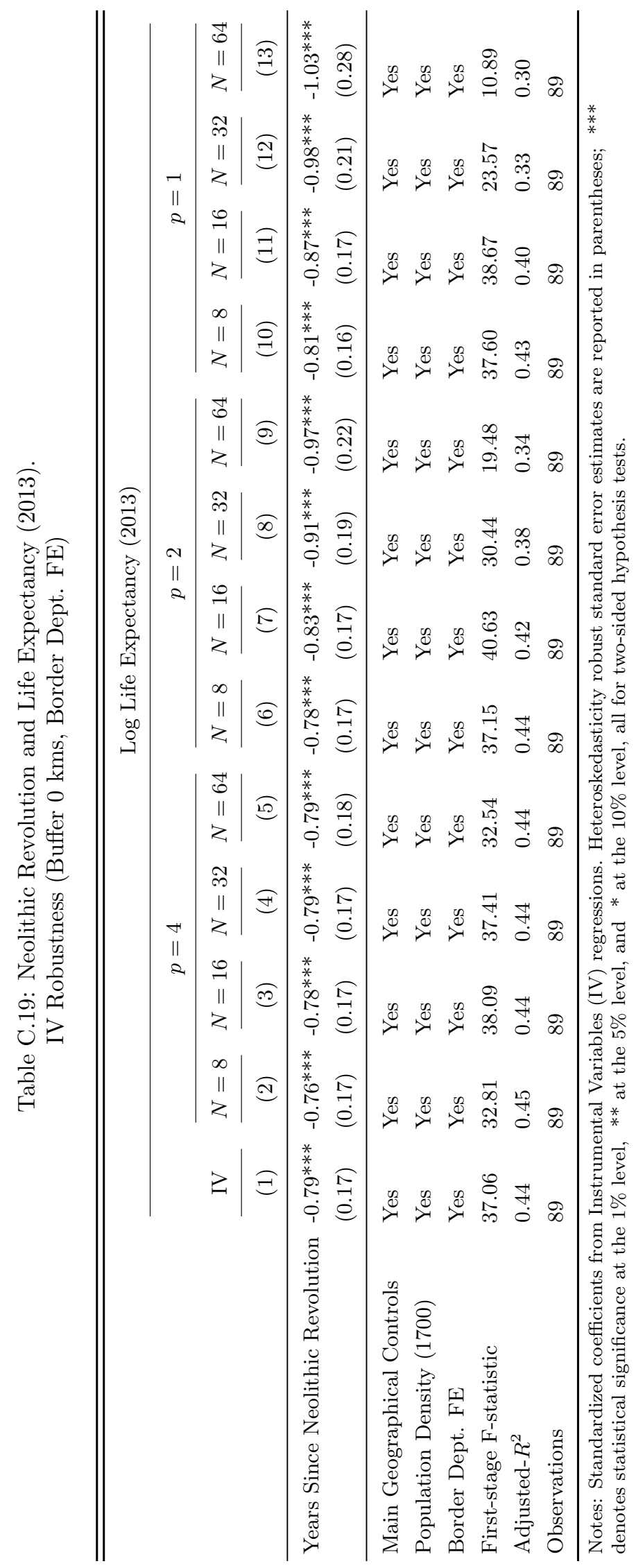




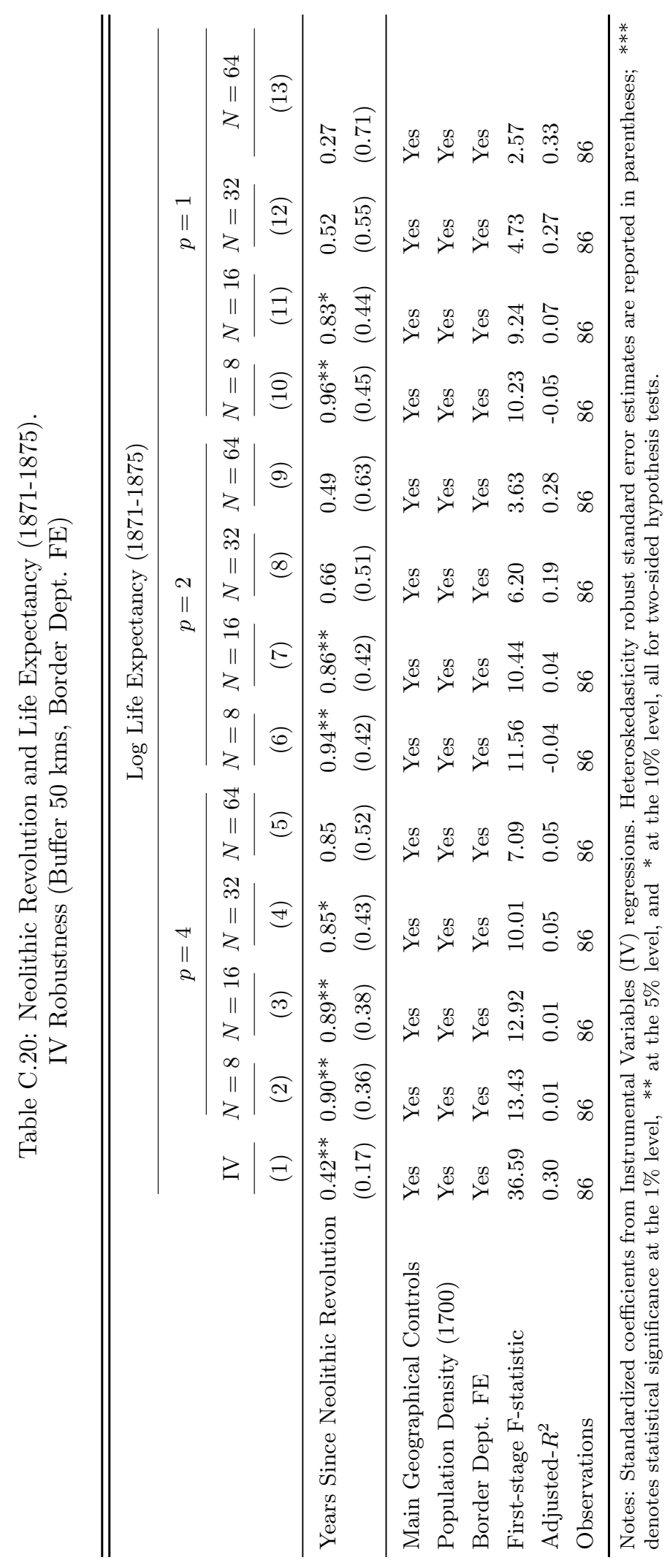




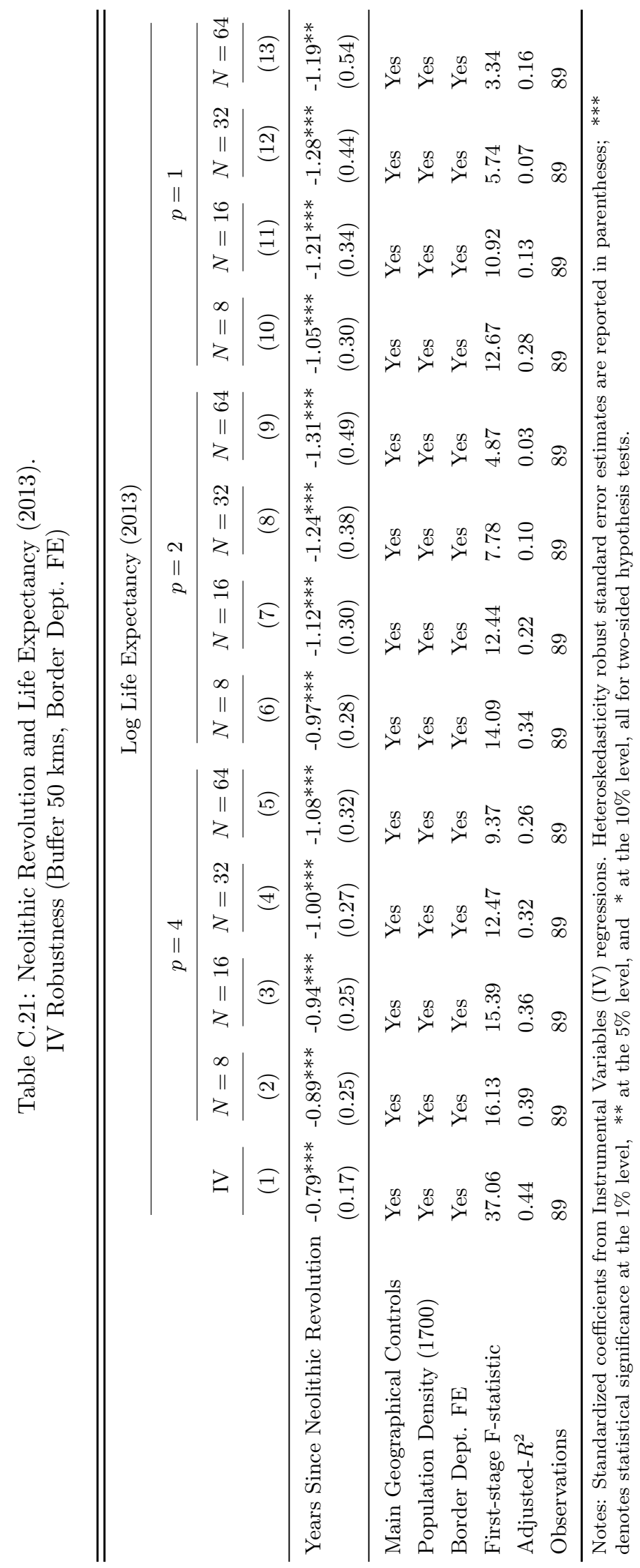




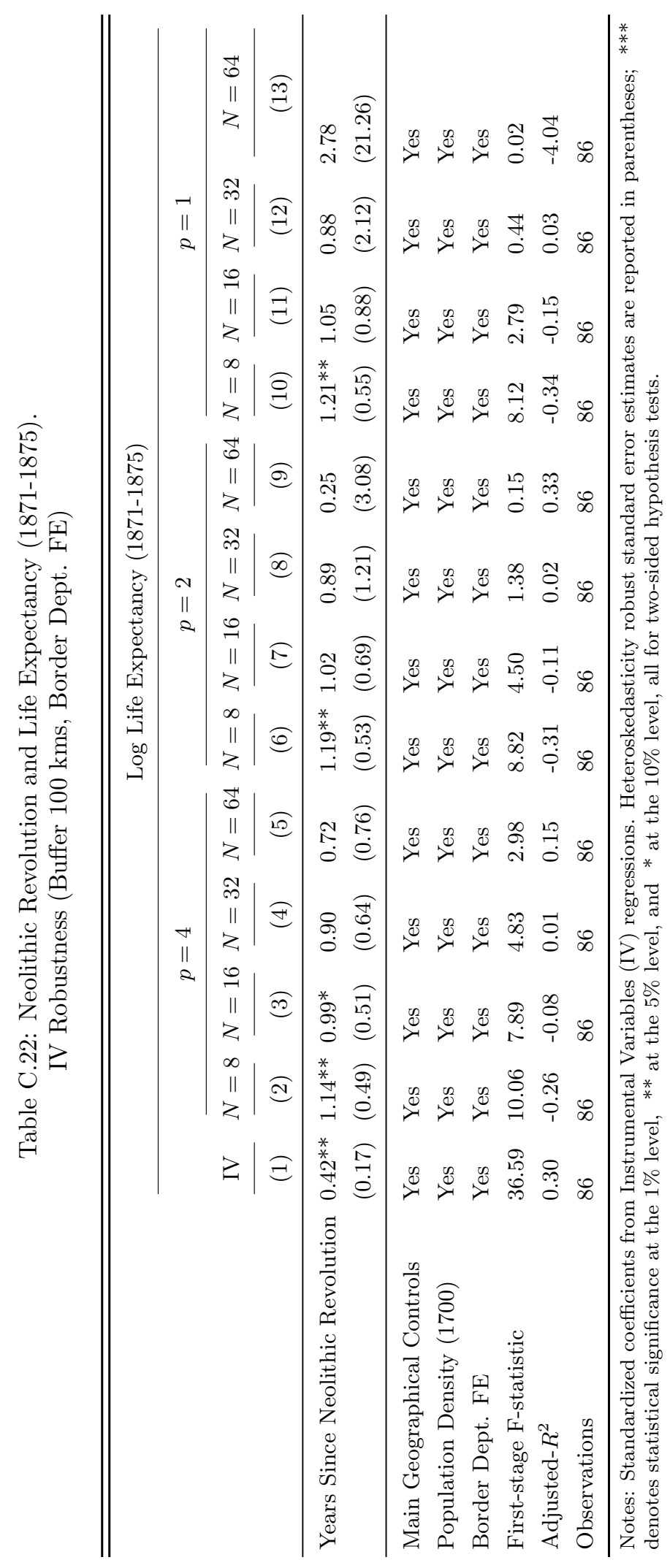




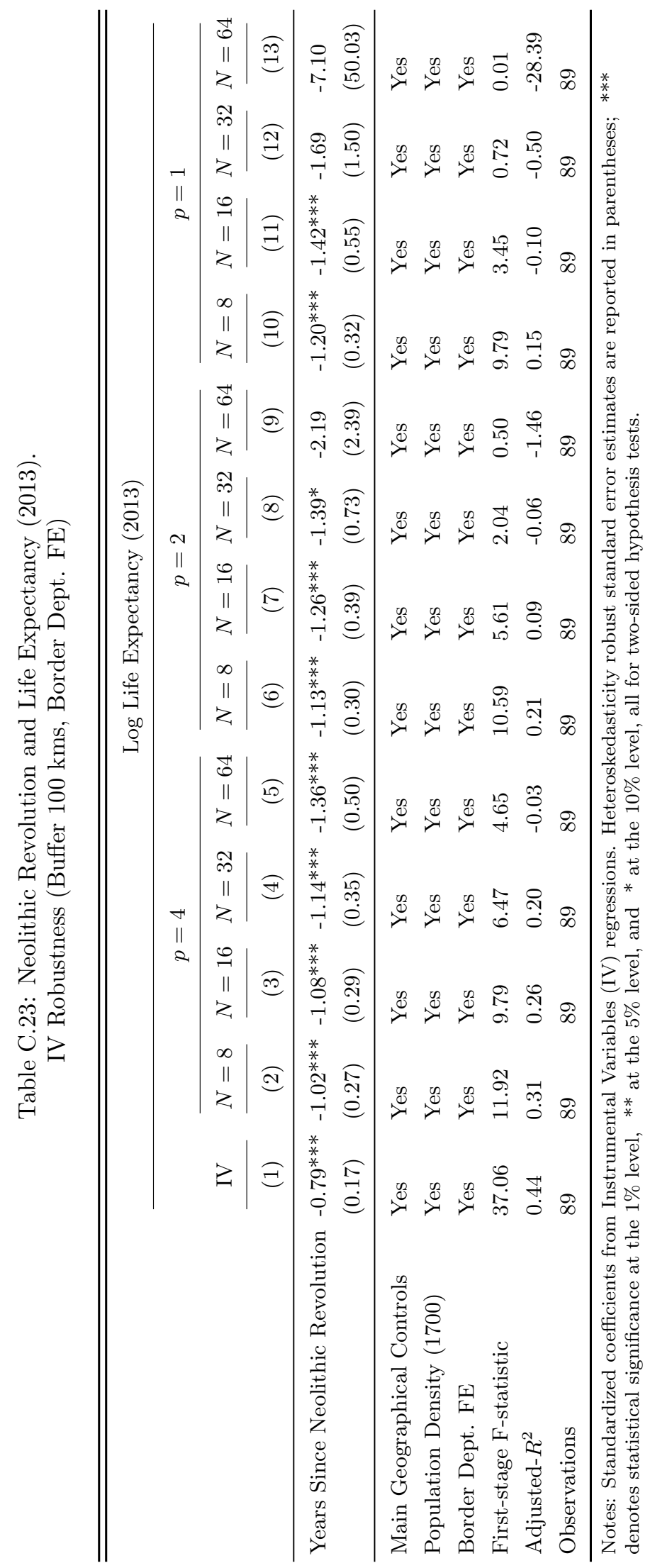




\section{The Diffusion of Agriculture: \\ Years Since Neolithic Revolution and Distance from Oldest Site}

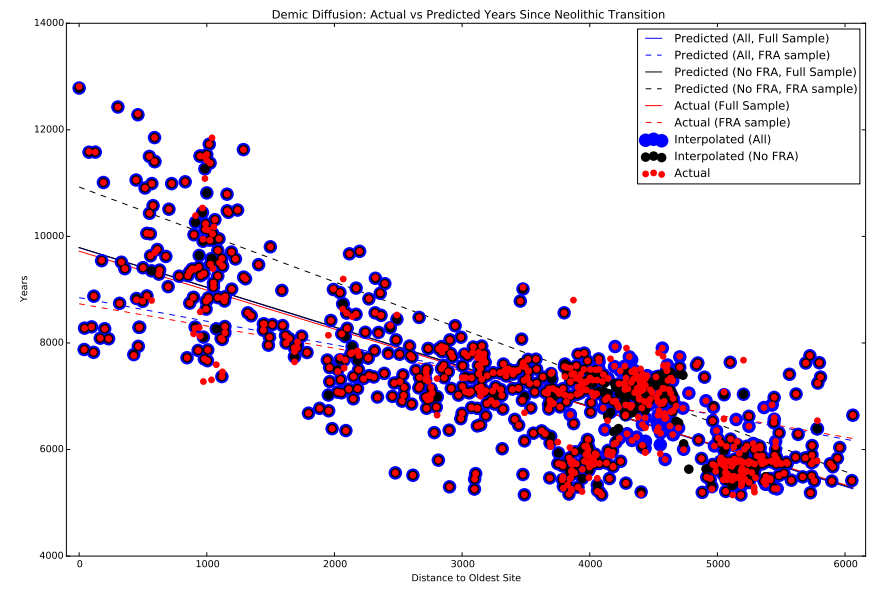

(a) Actual and Interpolated Years Since Neolithic Revolution

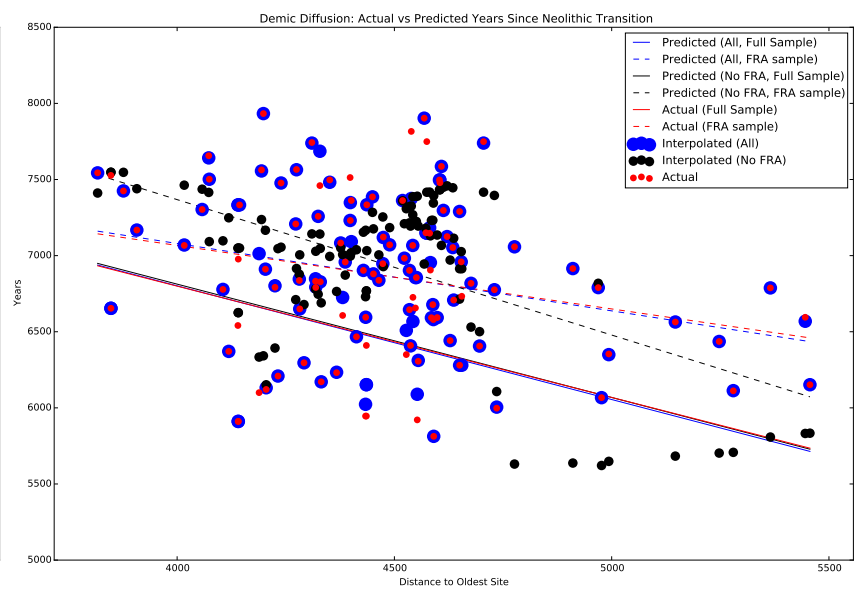

(b) Actual and Interpolated Years Since Neolithic Revolution (France)

Figure D.1: Demic Diffusion: Years Since Neolithic Revolution and Distance from Oldest Site

E Death Rates by Age and Disease (1950-1999) 


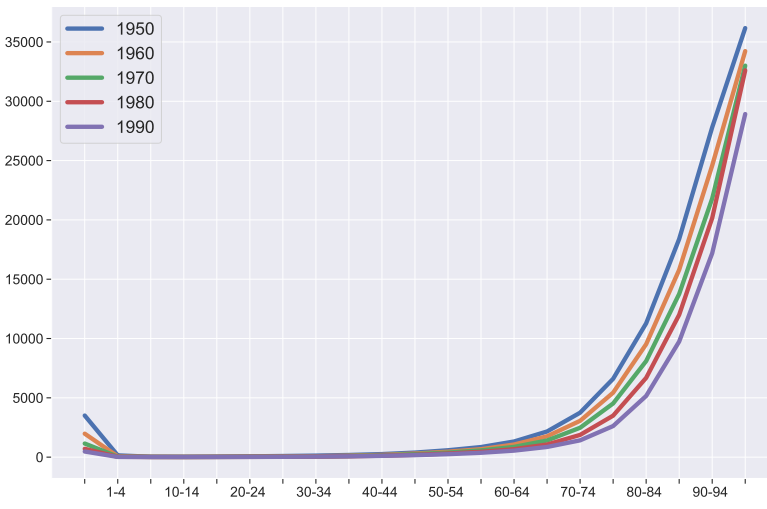

(a) All Diseases (Females)

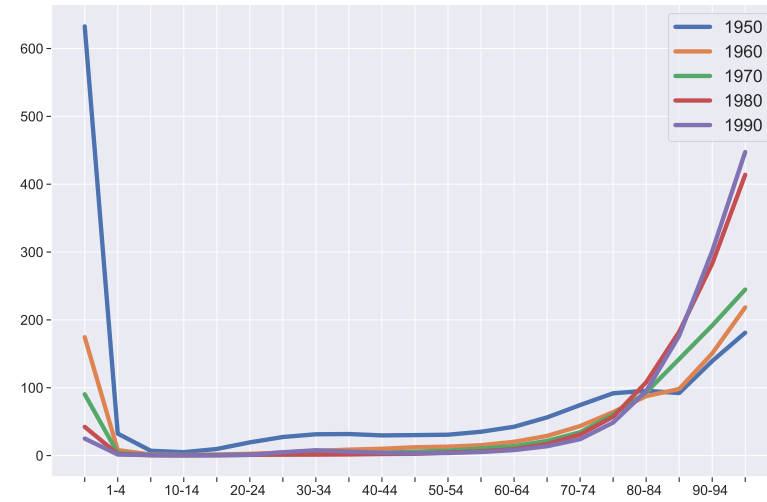

(c) Infectious and Parasitic (Females)

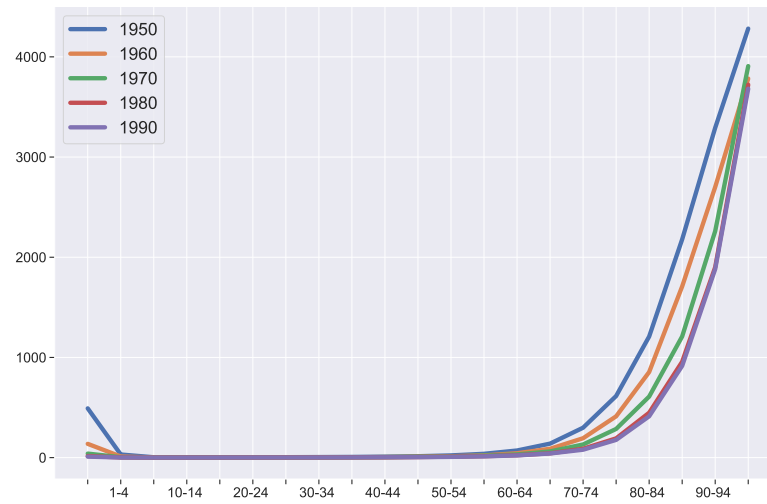

(e) Respiratory System (Females)

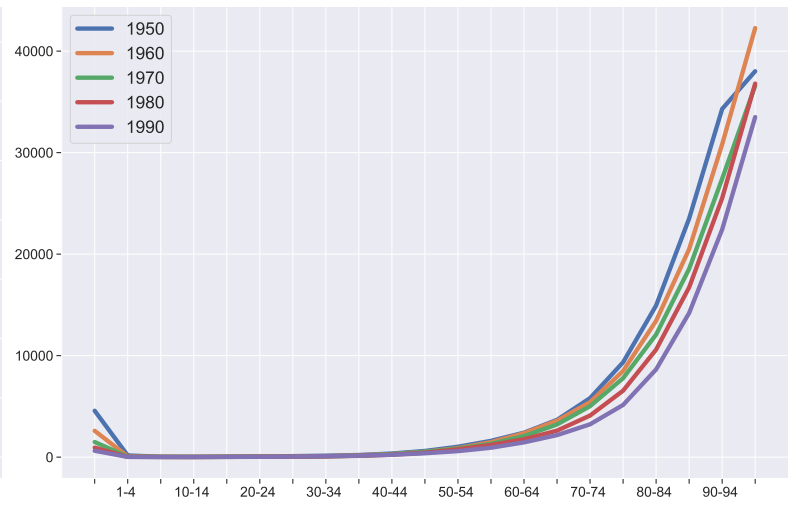

(b) All Diseases (Males)

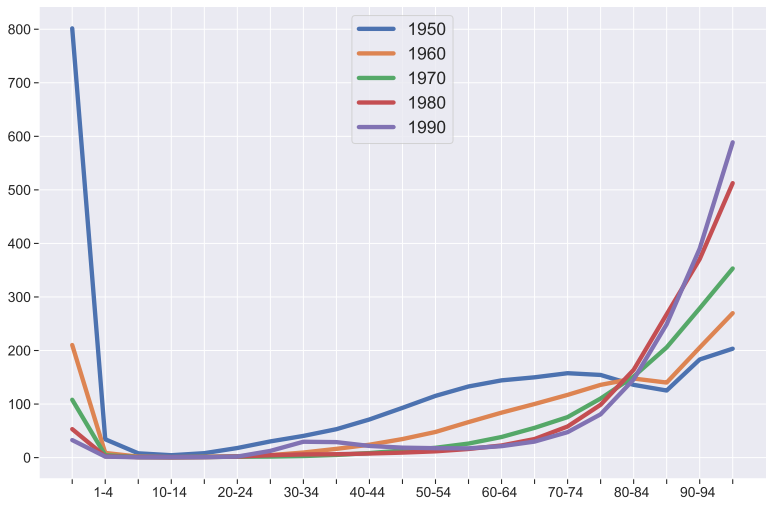

(d) Infectious and Parasitic (Males)

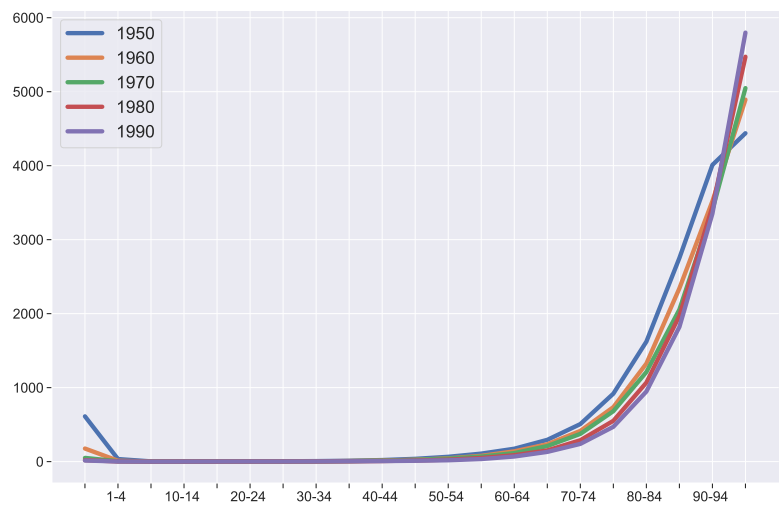

(f) Respiratory System (Males)

Figure E.1: Death Rates by Disease and Age in France (1950-1999, Decade Avg.) 


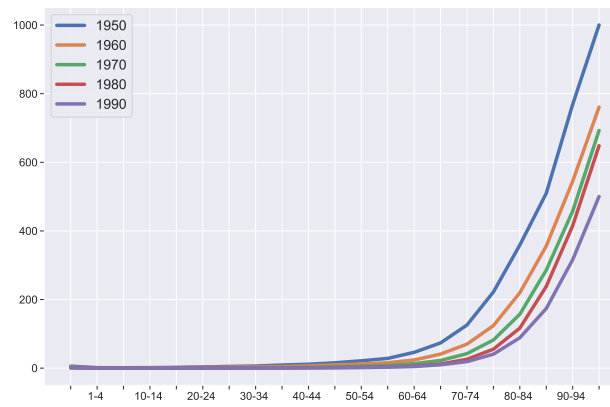

(g) Genito-Urinary Organs and Uremia Unspecified (Females)

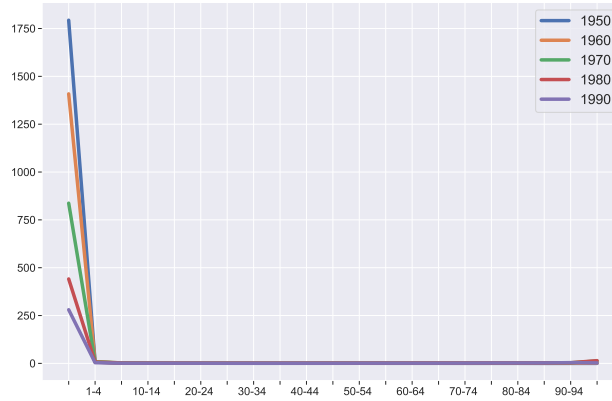

(i) Congenital Anomalies and Perinatal Conditions (Females)

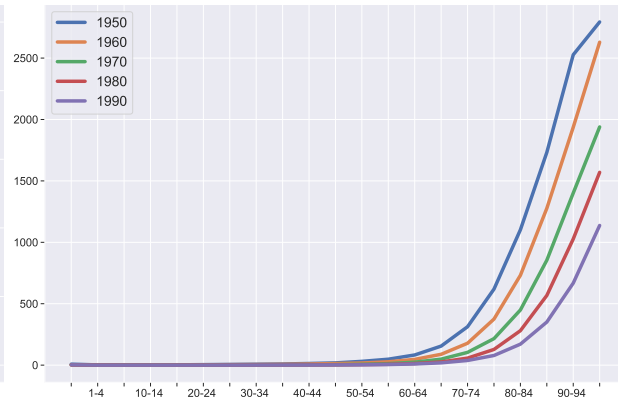

(h) Genito-Urinary Organs and Uremia Unspecified (Males)

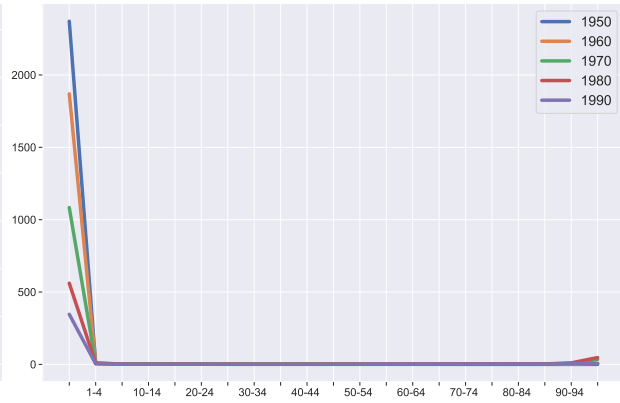

(j) Congenital Anomalies and Perinatal Conditions (Males)

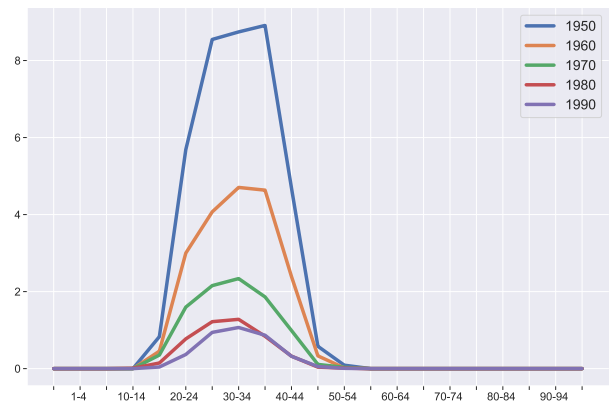

(k) Pregnancy Complications, Child Birth and Puerperium

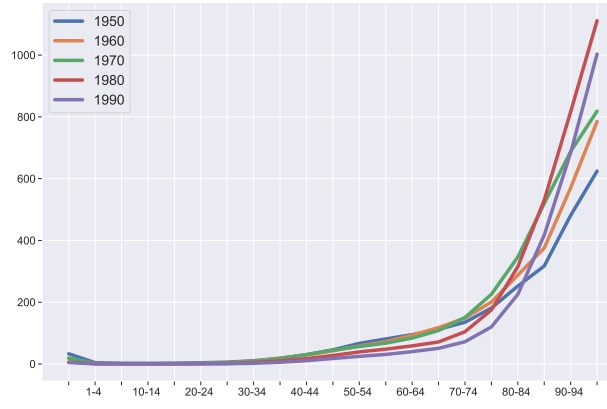

(1) Digestive System (Females)

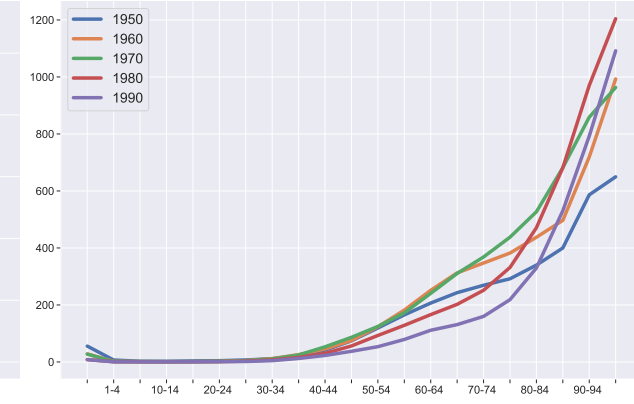

(m) Digestive System (Males)

Figure E.2: Death Rates by Disease and Age in France (1950-1999, Decade Avg.). Continued 


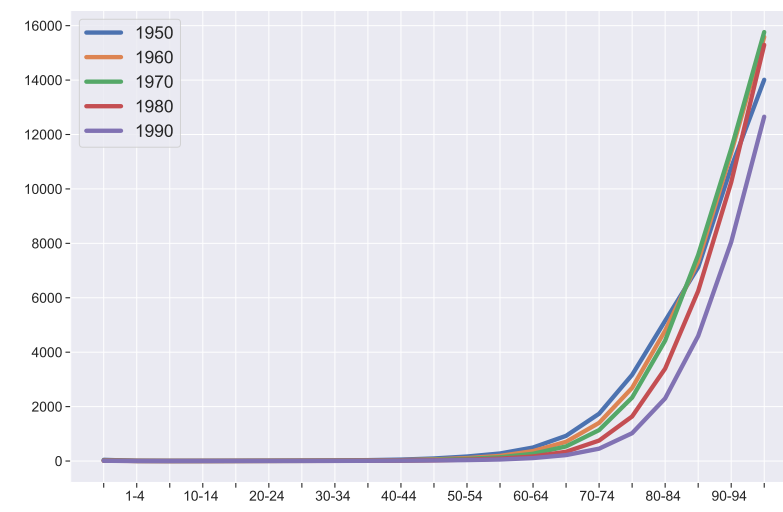

(n) Circulatory System (Females)

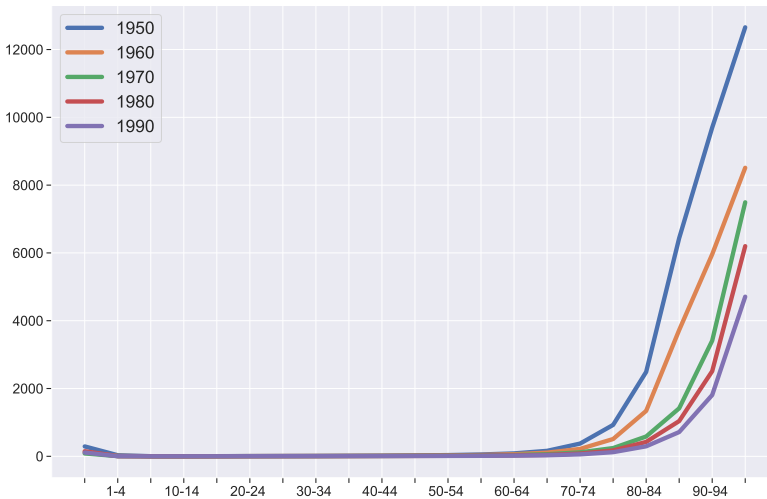

(p) Senility and Symptoms, and Ill-defined States (Females)

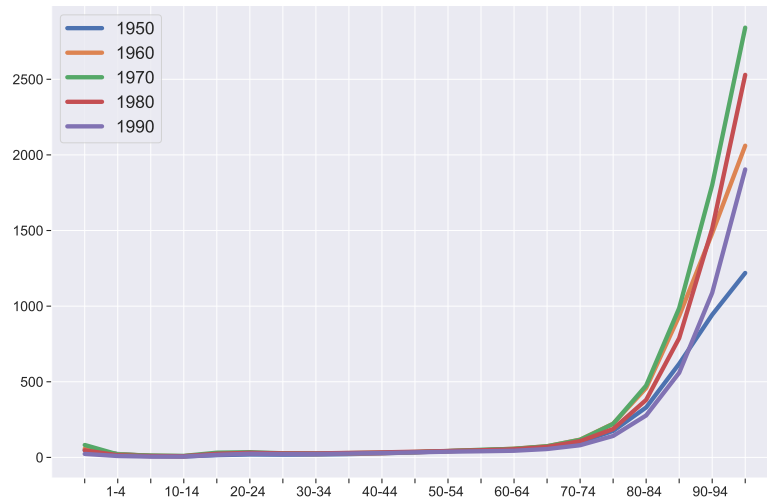

(r) Trauma and Poisoning (Females)

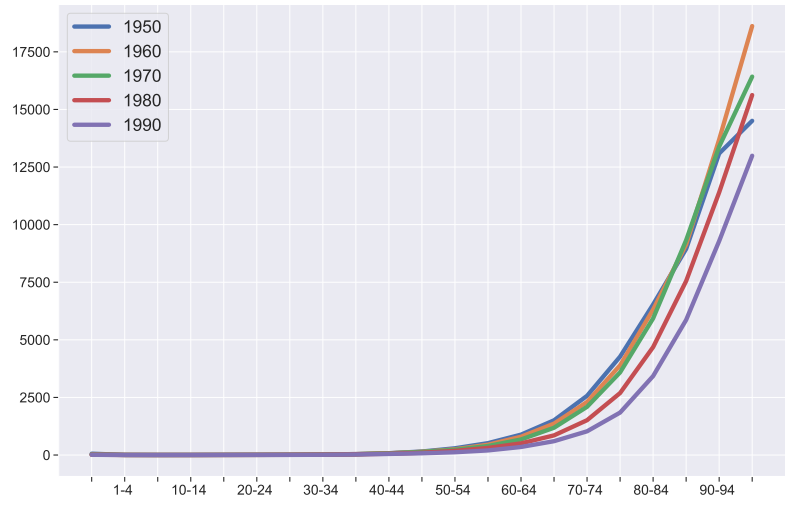

(o) Circulatory System (Males)

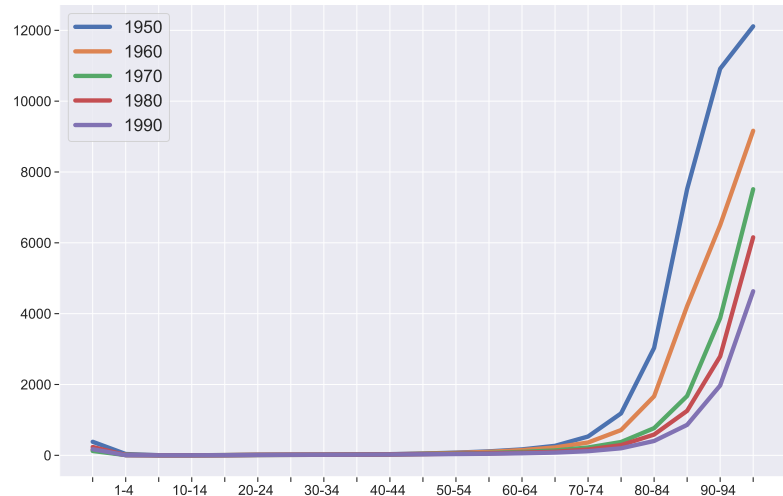

(q) Senility and Symptoms, and Ill-defined States (Males)

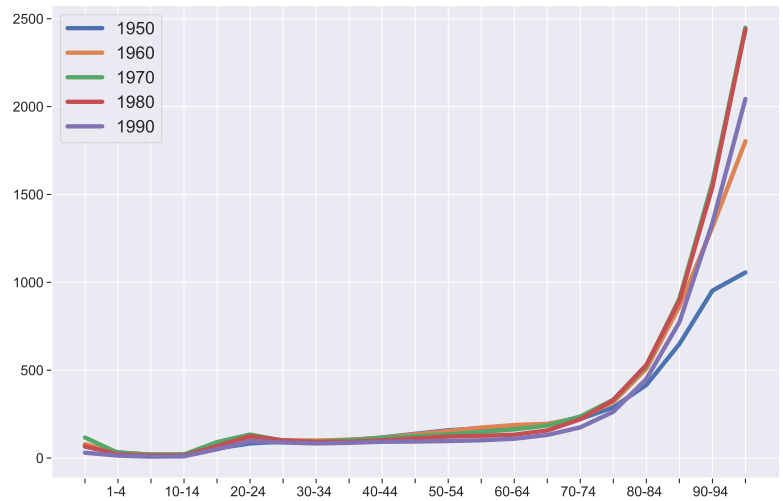

(s) Trauma and Poisoning (Males)

Figure E.3: Death Rates by Disease and Age in France (1950-1999, Decade Avg.) 


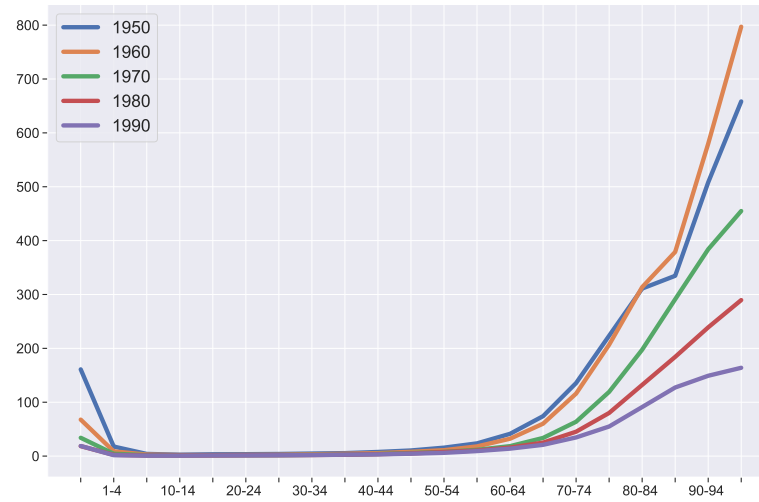

(t) Nervous System and Sense Organs (Females)

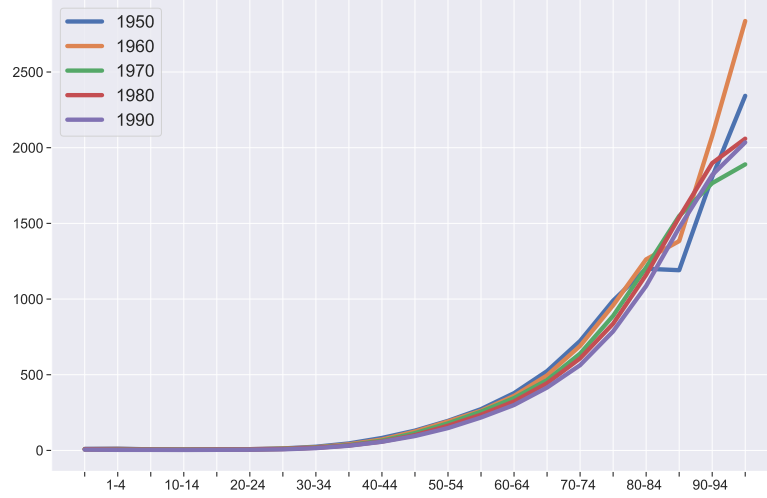

(v) Tumors (Females)

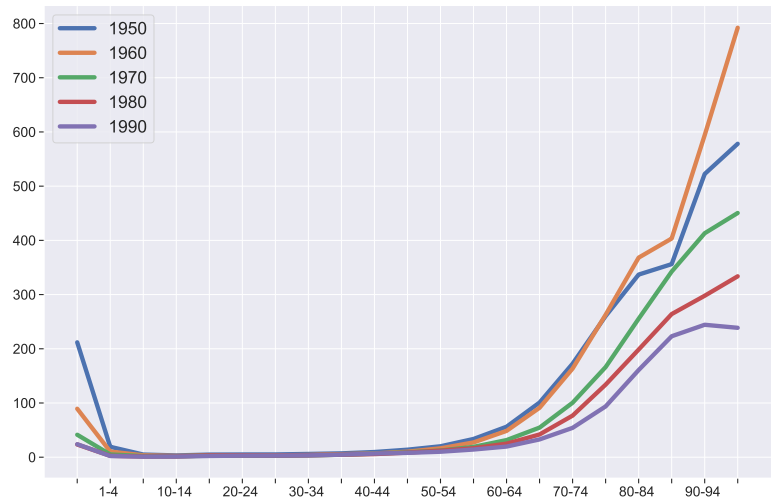

(u) Nervous System and Sense Organs (Males)

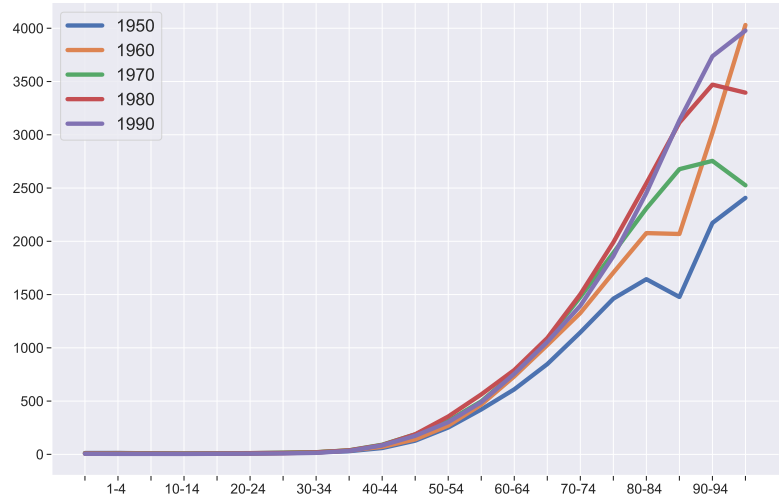

(w) Tumors (Males)

Figure E.4: Death Rates by Disease and Age in France (1950-1999, Decade Avg.). Continued 


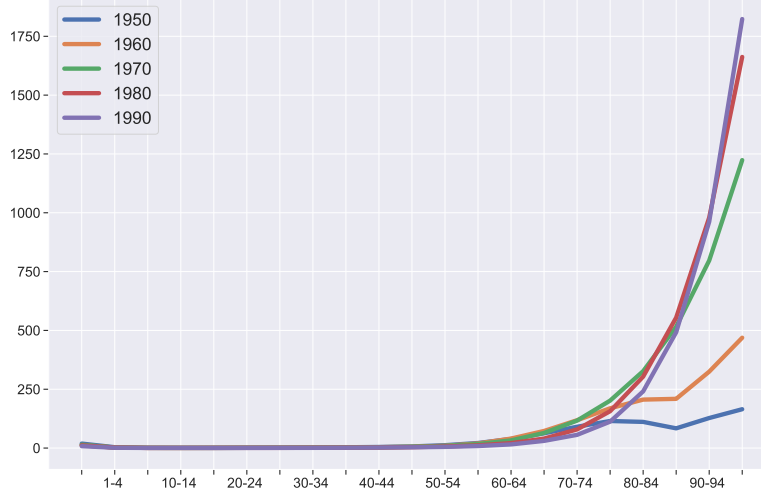

(a) Endocrine Diseases, Nutrition, Metabolism and Blood (Females)

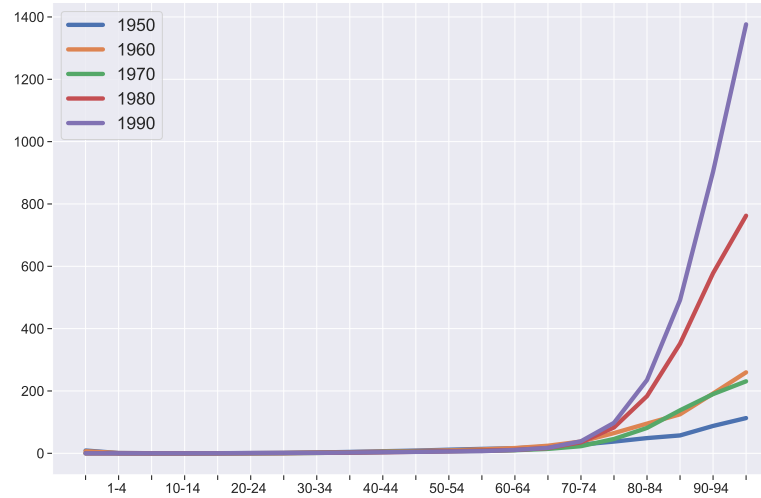

(c) Mental Disorders (Females)

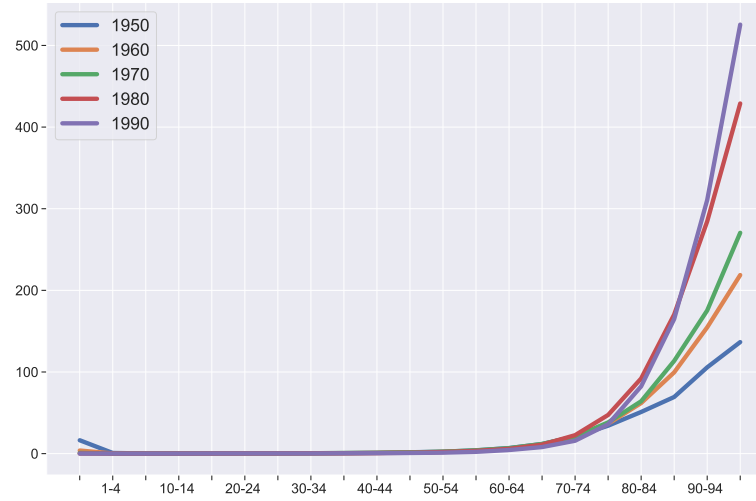

(e) Skin, Bones, Muscles and Connective Tissue (Females)

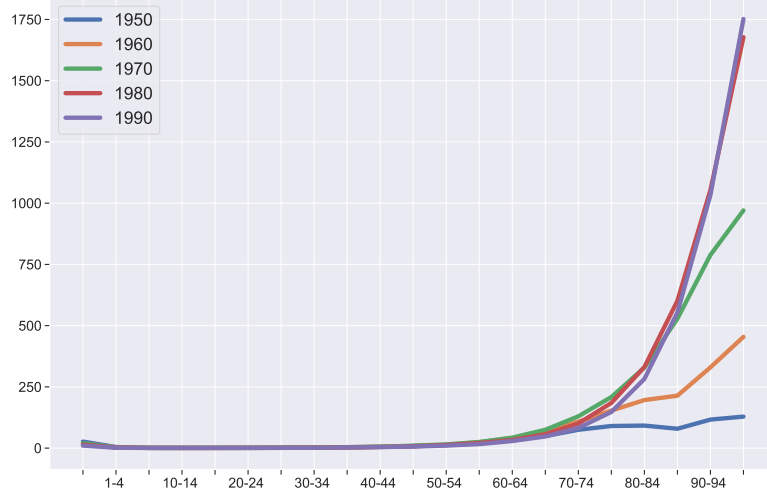

(b) Endocrine Diseases, Nutrition, Metabolism and Blood (Males)

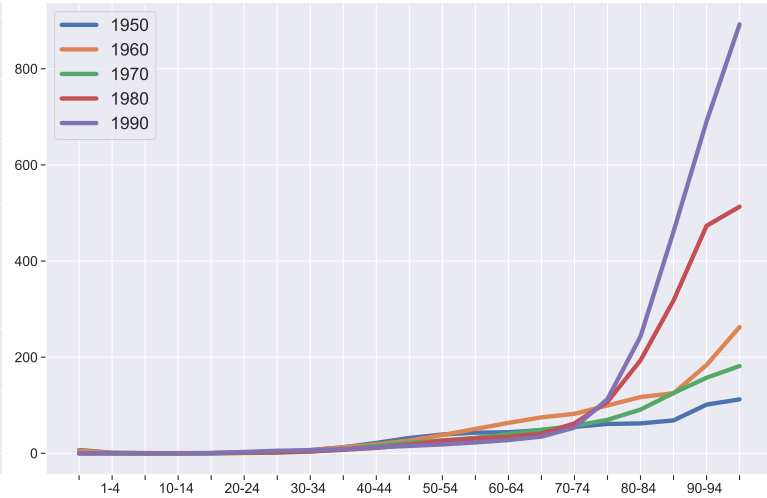

(d) Mental Disorders (Males)

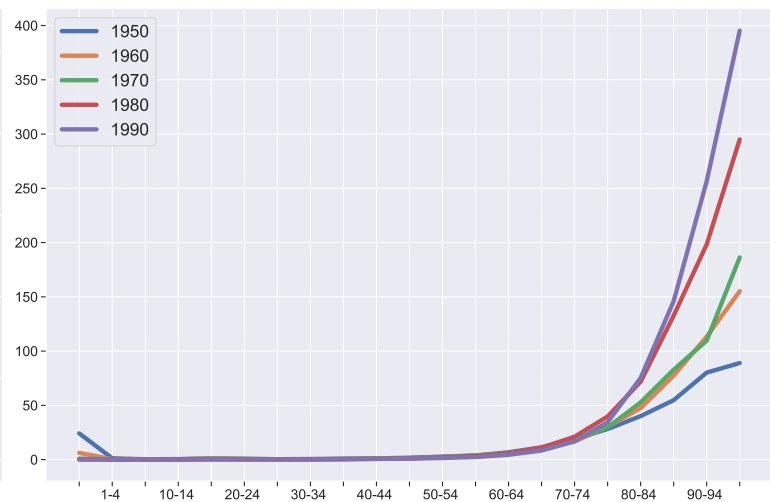

(f) Skin, Bones, Muscles and Connective Tissue (Males)

Figure E.5: Death Rates by Disease (Many Autoimmune) and Age in France (1950-1999, Decade Avg.) 


\section{F Variable definitions and sources}

\section{Dependent variables}

\section{Life expectancy at birth}

Life Expectancy. Each département's life expectancy for individuals at birth. Source: Direction de la Statistique Générale: Annuaire Statistique De La France (1875-1914), Bonneuil (1997), and French Institute of Statistics (Institut National des Statistiques et des Etudes Economiques - INSEE)

\section{Causes of mortality}

The sources of the causes of mortality are (France, 1901), the National institute for Demographic Studies (Institut National des Etudes Démographiques - INED) and the Institute for Research and Documentation in Health Economics (Institut de Recherche et de Documentation en Economie de la Santé - IRDES).

\section{Explanatory variables}

Average rainfall. The average rainfall in $\mathrm{cm}^{3}$, reported at a half-degree resolution by Ramankutty et al. (2002), across the French départements.

Average temperature. The average temperature (in celsius), reported at a half-degree resolution by Ramankutty et al. (2002), across the French départements.

Latitude. The latitude of the centroid of each French département.

Land Suitability The land suitability index, reported at a half-degree resolution by Ramankutty et al. (2002), across the French département.

Maritime département. This dummy variable takes the value one if a French department borders the coastline and zero otherwise.

Border département. This dummy variable takes the value one if a French department borders one of the foreign countries around France (Belgium, Luxembourg, Germany, Switzerland, Italy and Spain) and zero otherwise.

Population in 1700 (thousand of inhabitants). This variable reports the total population of the major urban centers, i.e., with more than 10,000 inhabitants, in each French département in 1700 using the data in Lepetit (1994, Appendix B).

Distance to Fresnes sur Escaut. The HMI distance from Fresnes-sur-Escaut, where the first steam engine was operated in France in 1732, to the administrative center of each département. This migratory distance is computed in weeks of travel.

\section{Additional control variables}

\section{University}

University. Number of universities in 1700 in each département. Source: Bosker et al. (2013).

\section{Railroad connection}

Railroad connection to Paris in 1860. This dummy variable takes the value 1 if the administrative center of the département was connected to the railroad network in 1860. Source: Caron (1997). 


\section{Income}

GDP per capita. Each département's GDP per capita. Source: Combes et al. (2011) and CaruanaGalizia (2013).

\section{Education Measures, Pre-WWI}

Share of Pupils 5-15 Enrolled in Primary Schools in 1876. Share of pupils 5-15 enrolled in primary schools in the département. Source: Diebolt et al. (2005).

Literate Consripts, 1874. The sources for the educational achievements French army conscripts, i.e., 20-year-old men who reported for military service in the département where their father lived, who could read and write in 1874 is Direction de la Statistique Générale: Annuaire Statistique De La France (1875-1914).

\section{Education Measures, Post-WWII.}

Share of men age 25 and above with a secondary or post-secondary degree, 2010. The share of men age 25 and above in the population of each département who at least completed secondary schooling. Source: The successive censuses conducted by the French bureau of statistics (INSEE Institut National de la Statistique et des Etudes Economiques) in 2010.

Share of women age 25 and above with a secondary or post-secondary degree, 2010. The share of women age 25 and above in the population of each département who at least completed secondary schooling. Source: The successive censuses conducted by the French bureau of statistics (INSEE Institut National de la Statistique et des Etudes Economiques) in 2010. 


\section{Appendix References}

Bonneuil, N. (1997). Transformation of the French Demographic Landscape, 1806-1906, Clarendon Press, Oxford, UK.

Bosker, M., Buringh, E. and van Zanden, J. L. (2013). From Baghdad to London: unravelling urban development in Europe and the Arab world 800-1800, Review of Economics and Statistics 95(4): 1418-1437.

Caron, F. (1997). Histoire des chemins de fer en France: 1740-1883, Fayard, Paris.

Caruana-Galizia, P. (2013). Estimating French regional income: departmental per capita gross value added, 1872-1911, Research in Economic History 29: 71-95.

Combes, P.-P., Lafourcade, M., Thisse, J.-F. and Toutain, J.-C. (2011). The rise and fall of spatial inequalities in France: a long-run perspective, Explorations in Economic History 48: 243-271.

Diebolt, C., Jaoul, M. and Martino, G. S. (2005). Le mythe de Ferry: une analyse cliométrique, Revue d'économie politique 115(4): 471-497.

Direction de la Statistique Générale: Annuaire Statistique De La France (1875-1914). Imprimerie Nationale, Paris.

France (1901). Direction de l'Assistance et de l'Hygiène Publiques: Statistique Sanitaire des Villes de France et d'Algérie, Imprimerie Nationale, Paris.

Lepetit, B. (1994). The Pre-Industrial Urban System: France, 1740-1840, Cambridge University Press, Cambridge, UK.

Ramankutty, N., Foley, J. A., Norman, J. and McSweeney, K. (2002). The global distribution of cultivable lands: current patterns and sensitivity to possible climate change, Global Ecology and Biogeography 11(5): 377 - 392 . 